\title{
EM TASK 12 - LASER CLEANING OF CONTAMINATED PAINTED SURFACES
}

Final Topical Report

Submitted to:

Federal Energy Technology Center

AAD Document Control

U.S. Department of Energy

PO Box 10940, MS 921-143

Pittsburgh, PA 15236-0940

Contract No. DE-FC21-94MC31388--32

Performance Monitor: Karl Heinz-Frohne
Submitted by:

Ames A. Grisanti Charlene R. Crocker

Robert R. Jensen

Energy \& Environmental Research Center University of North Dakota

PO Box 9018

Grand Forks, ND 58202-9018 


\section{DOE DISCLAIMER}

This report was prepared as an account of work sponsored by an agency of the United States Government. Neither the United States Government, nor any agency thereof, nor any of their employees makes any warranty, express or implied, or assumes any legal liability or responsibility for the accuracy, completeness, or usefulness of any information, apparatus, product, or process disclosed or represents that its use would not infringe privately owned rights. Reference herein to any specific commercial product, process, or service by trade name, trademark, manufacturer, or otherwise does not necessarily constitute or imply its endorsement, recommendation, or favoring by the United States Government or any agency thereof. The views and opinions of authors expressed herein do not necessarily state or reflect those of the United States Government or any agency thereof.

This report is available to the public from the National Technical Information Service, U.S. Department of Commerce, 5285 Port Royal Road, Springfield, VA 22161; phone orders accepted at (703) 487-4650.

\section{ACKNOWLEDGMENT}

This report was prepared with the support of the U.S. Department of Energy (DOE) Federal Energy Technology Center Cooperative Agreement No. DE-FC21-94MC31388. However, any opinions, findings, conclusions, or recommendations expressed herein are those of the authors(s) and do not necessarily reflect the views of DOE.

\section{EERC DISCLAIMER}

LEGAL NOTICE This research report was prepared by the Energy \& Environmental Research Center (EERC), an agency of the University of North Dakota, as an account of work sponsored by DOE. Because of the research nature of the work performed, neither the EERC nor any of its employees makes any warranty, express or implied, or assumes any legal liability or responsibility for the accuracy, completeness, or usefulness of any information, apparatus, product, or process disclosed, or represents that its use would not infringe privately owned rights. Reference herein to any specific commercial product, process, or service by trade name, trademark, manufacturer, or otherwise does not necessarily constitute or imply its endorsement or recommendation by the EERC.

\section{SOFTWARE DISCLAIMER}

LEGAL NOTICE: This computer program was prepared by the Energy \& Environmental Research Center (EERC), an agency of the University of North Dakota, as an account of work sponsored by the U.S. Department of Energy for Contract No. DE-FC21-94MC31388. The services performed, program apparatus, product, or process disclosed and accompanying documentation are provided "as is" without warranty of any kind —expressed, implied, or statutory, including warranties of merchantability and fitness for a particular purpose - except as stated herein. Neither the EERC nor any person acting on behalf of the EERC warrants, guarantees, or makes any representations regarding the use, or the results of the use, of the service performed, program, apparatus, product, or process disclosed, or the accompanying documentation, in terms of correctness, accuracy, reliability, currentness, or otherwise, except as stated herein. Nor does the EERC represent that the use of the service performed, program, apparatus, product, or process disclosed, or the accompanying documentation, will not infringe upon privately owned rights, including copyright, patent, and trademark rights. If the services performed, program, or accompanying documentation are defective, you, and not the EERC or its dealers, distributors, agents, or employees, assume the entire cost of all necessary servicing, repair, or correction except as stated herein. The EERC does not warranty that the operation of the program will be uninterrrupted or error-free. Reference herein to any specific commercial product, process, or service by the trade name, trademark, manufacturer, or otherwise does not necessarily constitute or imply its endorsement or recommendation by the EERC or any sponsor. 


\section{TABLE OF CONTENTS}

LIST OF FIGURES $\ldots \ldots \ldots \ldots \ldots \ldots \ldots \ldots \ldots \ldots \ldots \ldots \ldots \ldots \ldots \ldots \ldots \ldots \ldots$

LIST OF TABLES $\ldots \ldots \ldots \ldots \ldots \ldots \ldots \ldots \ldots \ldots \ldots \ldots \ldots \ldots$ ii

EXECUTIVE SUMMARY $\ldots \ldots \ldots \ldots \ldots \ldots \ldots \ldots \ldots \ldots \ldots \ldots$ iii

BACKGROUND $\ldots \ldots \ldots \ldots \ldots \ldots \ldots \ldots \ldots \ldots \ldots \ldots \ldots \ldots \ldots \ldots$

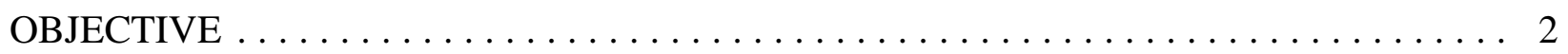

ACCOMPLISHMENTS $\ldots \ldots \ldots \ldots \ldots \ldots \ldots \ldots \ldots \ldots \ldots \ldots \ldots \ldots \ldots$

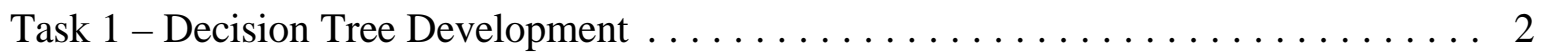

Task 2 - Literature Search for Surface Decontamination Reports . . . . . . . . . . . . 2

Task 3 - Compilation of Dataset from Literature Data . . . . . . . . . . . . . 2

Task 4 - Sensitivity Analysis and Model Design . . . . . . . . . . . . . . 3

Surface Removal Performance Index Calculation $\ldots \ldots \ldots \ldots \ldots \ldots \ldots \ldots$

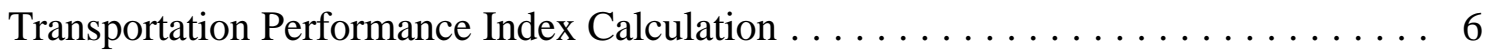

Waste Disposal Performance Index Calculation . . . . . . . . . . . . . . . 7

Environment, Health, and Safety Performance Index Calculation . . . . . . . . 8

Technology Implementation, Operation, and Maintenance Performance

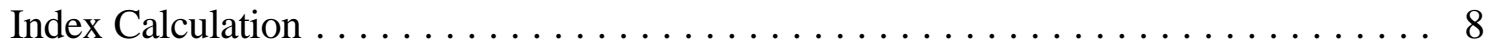

Overall Performance Index Calculation $\ldots \ldots \ldots \ldots \ldots \ldots \ldots \ldots$

Sensitivity Analyses . . . . . . . . . . . . . . . . . . . . . . 9

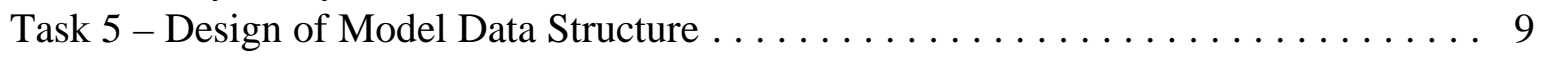

Task 6 - PC Software Design and Coding $\ldots \ldots \ldots \ldots \ldots \ldots \ldots \ldots \ldots \ldots \ldots \ldots \ldots$

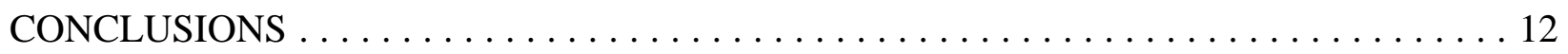

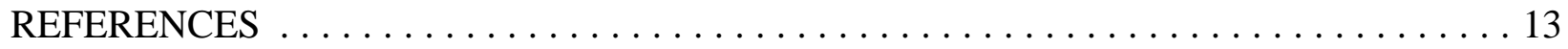

SURFACE DECONTAMINATION DECISION TREE ............ Appendix A

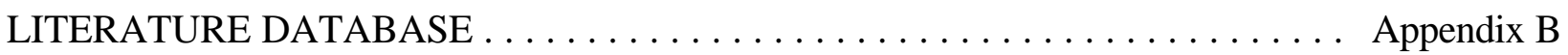

TECHNOLOGY DATASET $\ldots \ldots \ldots \ldots \ldots \ldots \ldots \ldots \ldots \ldots \ldots \ldots \ldots \ldots \ldots \ldots$ Appendix C

SURFACE DECONTAMINATION ASSISTANT MODEL . . . . . . . A Appendix D

MODEL DESIGN EQUATIONS $\ldots \ldots \ldots \ldots \ldots \ldots \ldots \ldots \ldots \ldots \ldots \ldots \ldots \ldots \ldots \ldots \ldots$ Appendix E

SURFACE DECONTAMINATION ASSISTANCE SENSITIVITY ANALYSES . Appendix F 


\section{TABLE OF CONTENTS (continued)}

SURFACE DECONTAMINATION ASSISTANT SOFTWARE DESIGN

AND OPERATION MANUAL $\ldots \ldots \ldots \ldots \ldots \ldots \ldots \ldots \ldots \ldots \ldots \ldots \ldots \ldots$ Appendix G

\section{LIST OF FIGURES}

$1 \quad$ Surface Decontamination Assistant software architecture $\ldots \ldots \ldots \ldots \ldots \ldots \ldots$

\section{LIST OF TABLES}

1 Surface Decontamination Assistant Model Test Scenarios $\ldots \ldots \ldots \ldots \ldots \ldots \ldots$ 


\section{EM TASK 12 - LASER CLEANING OF CONTAMINATED PAINTED SURFACES}

\section{EXECUTIVE SUMMARY}

Several techniques are available or under development for surface decontamination in nuclear facilities. Each technique has its merits; however, none of them is universally the best choice for all surface decontamination applications. Because of the multitude of factors which influence the environmental and economic aspects of selecting a surface decontamination technique, it is difficult to select the best method in a given situation; an objective basis for comparing techniques is needed.

The objective of this project was to develop a software tool for use by personnel selecting a surface decontamination technique. The software incorporates performance data for available surface decontamination techniques.

The beta release version of the Surface Decontamination Assistant Software has been completed and has undergone testing at the Energy \& Environmental Research Center. Minor modifications to the software were completed, and a final release version of the software is ready to be issued. 


\section{EM TASK 12 - LASER CLEANING OF CONTAMINATED PAINTED SURFACES}

\section{BACKGROUND}

Surface decontamination of concrete and steel surfaces in nuclear facilities provides cost savings during decommissioning operations by allowing recycling or reuse of concrete and steel structures. Separation of radionuclides and other contamination from the concrete or steel substrates also allows reduction in volume of hazardous materials during the D\&D (deactivation and decommissioning) process, resulting in further cost savings.

Several techniques are available or under development for surface decontamination in nuclear facilities. Each technique has its merits; however, none of them is universally the best choice for all surface decontamination applications. Some issues confronting an organization selecting a surface decontamination technique for a particular application are as follows:

- Project scale

- Concrete or metal surfaces

- Contamination by radiological and other hazardous materials

- Stage of surface decontamination technology development (e.g., commercial, R\&D [research and development])

- Equipment operating costs

- Collection of waste generated by surface decontamination

- Occupational health and safety requirements

- Utilities required for operations

- Real-time control of surface decontamination

- Recycling or reuse of decontaminated substrates

- Waste

- Characterization

- Classification

- Transport

- Storage

- Treatment

- Disposal

- D\&D equipment decontamination

Because of the multitude of factors that influence the environmental and economic aspects of selecting a surface decontamination technique, it is difficult to select the best method in a given situation. An objective basis for comparing techniques is needed. 


\section{OBJECTIVE}

The objective of this project is to develop a software tool for use by personnel selecting a surface decontamination technique. The software will incorporate performance data for available surface decontamination techniques.

The major activities in the project are broken down as follows:

- Task 1 - Decision Tree Development

- Task 2 - Literature Search for Surface Decontamination Reports

- Task 3 - Compilation of Dataset from Literature Data

- Task 4 - Sensitivity Analysis and Model Design

- Task 5 - Design of Model Data Structure

- Task 6-PC Software Design and Coding

\section{ACCOMPLISHMENTS}

\section{Task 1 - Decision Tree Development}

The surface decontamination decision tree developed over the course of this project is depicted in Figures A1 through A3 of Appendix A. The decision tree functions as a framework for design and implementation of the computer model, allowing comparison of surface decontamination technologies.

\section{Task 2 - Literature Search for Surface Decontamination Reports}

Literature pertaining to surface decontamination applied in D\&D operations was identified and acquired using a number of information resources, including the Remedial Action Program Information Center (RAPIC), the U.S. Department of Energy (DOE) Information Bridge, DIALOG database, Current Contents, and other traditional literature search tools. A complete list of the documents in the literature database for this work is given in Appendix B.

\section{Task 3 - Compilation of Dataset from Literature Data}

Available data on surface decontamination operations have been gleaned from available reports. Several articles (1-8) contain evaluations of surface decontamination techniques for specific cases. Data have been compiled from a number of articles and an attempt made to put the data into a form allowing technology comparisons to be made.

In addition to technology performance data gleaned from the literature, a survey of surface removal equipment vendors was completed to obtain additional information for the technology dataset. A listing of the dataset as incorporated into the computer model is given in Appendix C. 
Some of the performance data in the dataset are vendor-supplied, and portions of the technology entries were extracted from data collected under less-than-optimal experimental conditions. Therefore, the program is designed to allow additional technologies to be added as well as modifications to the performance data for technologies already resident in the dataset. Modifications and additions to the dataset will maximize the utility of the Surface Decontamination Assistant (SDA) model.

\section{Task 4 - Sensitivity Analysis and Model Design}

The model is designed to provide an overall performance index for each applicable surface decontamination technique under a user-defined application scenario. The overall performance index is an aggregate value derived from intermediate performance indices for the major aspects of the surface decontamination process. As defined in the SDA model, intermediate performance indices are computed for the following:

- Surface removal

- Waste transportation

- Waste disposal

- Environment, health, and safety (EH\&S)

- Technology implementation, operation, and maintenance

A number of assumptions are built into the current form of the SDA model. Assumptions intrinsic to the execution of the model are as follows:

1. Types of surface contamination are known.

2. Surface coating composition and thickness are known.

3. Depth of surface contamination is known.

4. Technologies are capable of achieving $100 \%$ surface decontamination.

5. If only portions of the surface are contaminated, they may be cleaned separately in order to segregate the hazardous from nonhazardous waste.

6. Operation costs are based on a vendor service cost, including technology deployment and transportation to the site of application.

7. Practitioners are willing to employ more than one technique to achieve $100 \%$ surface decontamination.

8. No transuranic waste (TRU) or spent nuclear fuel (SNF) is part of the surface decontamination waste stream.

9. Solid and liquid waste streams may or may not be separated. 
10. If solid and liquid waste streams are not separated, uniform mixing takes place.

11. On-site waste disposal will employ existing vehicles and personnel.

12. All waste shipments are full loads for the style of transport.

As described above, the model will provide a comparison of techniques based on a userdefined application scenario. The user inputs to the model are as follows:

- Site name, location, substrate, and contamination descriptions

- Surface type (e.g., floor, ceiling) and material (steel or concrete)

- Surface area to be decontaminated, amount of surface that is hard to reach, coating thickness, and substrate removal thickness

- General categories of contamination (e.g., radionuclides)

- Surface area that is contaminated in each category

- Type of transportation for wastes (truck or rail)

- Transportation distance to on- and off-site storage and disposal facilities for remotehandled, contact-handled, and nonhazardous material

- Transportation and disposal costs

- Surface decontamination technologies to be included in the analysis

- Priority ranking for EH\&S; operational, maintenance, and reliability issues; surface removal costs; transportation costs; and disposal costs

Details of the SDA model implementation are given in Appendix D.

Calculation of each of the performance indices is carried out using the user-defined application scenario and the performance data for each technology selected by the use from the technology performance dataset.

Derivation of performance indices has been determined for surface removal; waste transportation; waste disposal; EH\&S; and technology implementation, operation, and maintenance. They have been defined as described below. Detailed equations as included in Appendix E. 


\section{Surface Removal Performance Index Calculation}

Calculation of the surface removal performance index is carried out by first estimating the time required to decontaminate (remove) the surface for each selected technology using Equation 1.

$$
T_{T}=\left[\left(H R_{F}-1\right) \cdot H R_{S}+A_{S}\right] \cdot \frac{N P_{T}}{P R_{T}}
$$

Where:

$\mathrm{T}_{\mathrm{T}} \quad=$ Total time for surface decontamination (removal) [time]

$\mathrm{HR}_{\mathrm{F}} \quad=$ Technology correction factor for hard to reach areas [unitless]

$\mathrm{HR}_{\mathrm{S}} \quad=$ Surface area to be cleaned that is hard to reach [length $\left.{ }^{2}\right]$

$\mathrm{A}_{\mathrm{S}} \quad=$ Total area to be cleaned [length $\left.{ }^{2}\right]$

$\mathrm{NP}_{\mathrm{T}} \quad=$ Number of passes needed to remove surface [unitless]

$\mathrm{PR}_{\mathrm{T}} \quad=$ Technology production rate [length $2 /$ time]

The surface removal performance index, which is a basis for comparison of technologies, is estimated using Equation 2. Equation 2 calculates a cost for each technology to complete the surface decontamination. The cost rate to operate the technology is calculated in dollars per unit time using the operating cost of the technology $\left(\mathrm{C}_{\mathrm{T}}\right)$ in dollars per square foot, the production rate of each technology $\left(\mathrm{PR}_{\mathrm{T}}\right)$ in square foot per time, and a labor charge in dollars per unit time. This total cost rate and the time $\left(\mathrm{T}_{\mathrm{T}}\right)$ estimated from Equation 1 are used to determine an operational cost for each technology in the user's application scenario. A setup cost $\left(\mathrm{S}_{\mathrm{T}}\right.$ times $\left.\mathrm{S}_{\mathrm{F}}\right)$ is added to the estimated operating cost to cover costs associated with the setup of each technology. The three categories included are portability of equipment, capital costs, and complexity of calibration. Detailed information is included in the dataset in Appendix C. Then each cost estimated is compared on the basis of the technology that is the least expensive to apply in surface decontamination. Although this method is a less conventional approach than normalization, the result is a surface removal performance index for each technology that ranges in value from 0 to 1 , with 1 being the least expensive technology to apply.

$$
\mathrm{PI}_{\mathrm{SR}}=\frac{\min \left[\left(C_{T} \cdot P R_{T}+F_{L} \cdot N W_{T} \cdot C_{L}\right) \cdot T_{T}+\left(S_{T} \cdot S_{F}\right)\right]}{\left(C_{T} \cdot P R_{T}+F_{L} \cdot N W_{T} \cdot C_{L}\right) \cdot T_{T}+\left(S_{T} \cdot S_{F}\right)}
$$

Where:

$\mathrm{PI}_{\mathrm{SR}}=$ Surface removal performance index [unitless]

$\mathrm{C}_{\mathrm{T}} \quad=$ Technology operating cost [dollars/length $\left.{ }^{2}\right]$

$\mathrm{PR}_{\mathrm{T}} \quad=$ Technology production rate [length $\left.{ }^{2} / \mathrm{time}\right]$

$\mathrm{F}_{\mathrm{L}}=$ Boolean variable indicating that labor is not included in operating costs [unitless]

$\mathrm{NW}_{\mathrm{T}} \quad=$ Number of workers needed to operate the technology [unitless]

$\mathrm{C}_{\mathrm{L}} \quad=$ Labor cost of the technology [dollars/time] 
$\mathrm{T}_{\mathrm{T}} \quad=$ Total time for surface decontamination (removal) [time]

$\mathrm{S}_{\mathrm{T}} \quad=$ Technology correction factor for setup of technologies [unitless]

$\mathrm{S}_{\mathrm{F}} \quad=$ Setup modification factor [dollars]

\section{Transportation Performance Index Calculation}

Calculation of the transportation performance index requires estimation of transport cost for all modes of transport for all potential types of waste. As an example, the calculation of on-site truck transport of contact-handled hazardous waste is outlined in Equation 3.

$$
C T O n_{C H}=F_{T} \cdot F_{O S} \cdot\left(\frac{M S_{T} \cdot \frac{M_{C H}}{M S_{T}+M L_{T}}}{M S T_{C H}}\right) \cdot\left(C_{C H T} \cdot D+M T_{C H T}\right)
$$

Where:

$\mathrm{CTOn}_{\mathrm{CH}}=$ On-site truck transport cost of contact-handled hazardous waste [dollars]

$\mathrm{F}_{\mathrm{T}} \quad=$ Boolean variable indicating mode of transport (truck or rail) [unitless]

$\mathrm{F}_{\mathrm{OS}} \quad=$ Boolean variable indicating on-site disposal of contact-handled waste [unitless]

$\mathrm{MS}_{\mathrm{T}}=$ Total mass of solid waste [mass]

$\mathrm{M}_{\mathrm{CH}} \quad=$ Mass of contact-handled waste [mass]

$\mathrm{ML}_{\mathrm{T}} \quad=$ Total mass of liquid waste generated by the technology [mass]

$\mathrm{MST}_{\mathrm{CH}}=$ Maximum capacity of truck hauling contact-handled waste [mass]

$\mathrm{C}_{\mathrm{CHT}}=$ Cost to transport contact-handled waste by truck [dollars/length]

$\mathrm{D}=$ Distance from remediation site to storage/disposal site [length]

$\mathrm{MT}_{\mathrm{CHT}}=$ Cost to maintain truck used to haul contact-handled waste [dollars]

The transportation performance index represents a comparison of technologies based on the sum of all potential transportation costs. Equation 4 shows the formula for calculation of the index. Detailed equations for the other components are included in Appendix E. Because lower costs are preferable, the transport cost of chosen technologies is compared to the minimum transport cost for all technologies, rather than the more traditional method of normalizing the data to the maximum for all technologies. The resultant transportation performance index for each technology ranges in value from 0 to 1 , with 1 incurring the least transportation costs.

$$
P I_{T}=\frac{\min \left(C T O n_{C H}+C T O f f_{C H}+C T O f f_{R H}+C T O n_{R H}+C R_{C H}+C T O n_{C D}\right)+1}{\left(C T O n_{C H}+C T O f f_{C H}+C T O f f_{R H}+C T O n_{R H}+C R_{C H}+C T O n_{C D}\right)+1}
$$

Where:

$\mathrm{PI}_{\mathrm{T}} \quad=$ Transportation performance index [unitless] 
$\mathrm{CTOn}_{\mathrm{CH}}=$ On-site truck transport cost of contact-handled hazardous waste [dollars]

CTOff $_{\mathrm{CH}}=$ Off-site truck transport cost of contact-handled hazardous waste [dollars]

$\mathrm{CTOn}_{\mathrm{RH}}=$ On-site truck transport cost of remote-handled hazardous waste [dollars]

$\mathrm{CTOff}_{\mathrm{RH}}=$ Off-site truck transport cost of remote-handled hazardous waste [dollars]

$\mathrm{CR}_{\mathrm{CH}}=$ Rail transport cost of contact-handled hazardous waste [dollars]

$\mathrm{CTOn}_{\mathrm{CD}}=$ On-site truck transport cost of nonhazardous waste [dollars]

\section{Waste Disposal Performance Index Calculation}

Calculation of the waste disposal performance index requires estimation of disposal costs for all potential waste types. Equation 5 details the calculation for the volume of solid contacthandled waste, one component of the waste disposal performance index.

$$
V S_{C H}=V S_{T} \cdot \frac{V_{C H}}{\left(V S_{T}+V L_{T}\right)}
$$

Where:

$\mathrm{VS}_{\mathrm{CH}}=$ Volume of solid contact-handled waste [length ${ }^{3}$ ]

$\mathrm{VS}_{\mathrm{T}} \quad=$ Total volume of solid waste [length $\left.{ }^{3}\right]$

$\mathrm{V}_{\mathrm{CH}} \quad=$ Volume of contact-handled waste [length ${ }^{3}$ ]

$\mathrm{VL}_{\mathrm{T}} \quad=$ Volume of liquid contact-handled waste generated by the technology [length $\left.{ }^{3}\right]$

The waste disposal performance index compares techologies based on disposal costs associated with the volume of each type of waste. Equation 6 expresses the performance index. Detailed equations for the other components are located in Appendix E. As was the case in the previously discussed performance indices, the waste disposal index divides the minimum valued technology by each technology's value to obtain an index number between 0 and 1 .

$$
P I_{W D}=\frac{\min \left(f S_{C D} \cdot V S_{C D}+f L_{R H} \cdot V L_{R H}+f S_{R H} \cdot V S_{R H}+f L_{C H} \cdot V L_{C H}+f S_{C H} \cdot V S_{C H}\right.}{f S_{C D} \cdot V S_{C D}+f L_{R H} \cdot V L_{R H}+f S_{R H} \cdot V S_{R H}+f L_{C H} \cdot V L_{C H}+f S_{C H}} \cdot V S_{C H}
$$

Where:

$\mathrm{PI}_{\mathrm{WD}} \quad=$ Waste disposal performance issues [unitless]

$\mathrm{fS}_{\mathrm{CD}} \quad=$ Relative disposal cost factor for nonhazardous waste [unitless]

$\mathrm{VS}_{\mathrm{CD}}=$ Volume of solid nonhazardous waste [length ${ }^{3}$ ]

$\mathrm{fL}_{\mathrm{RH}} \quad=$ Relative disposal cost factor for liquid remote-handled waste [unitless]

$\mathrm{VL}_{\mathrm{RH}}=$ Volume of liquid remote-handled waste [length ${ }^{3}$ ]

$\mathrm{fS}_{\mathrm{RH}}=$ Relative disposal cost factor for solid remote-handled waste [unitless]

$\mathrm{VS}_{\mathrm{RH}}=$ Volume of solid remote-handled waste [length $\left.{ }^{3}\right]$

$\mathrm{fL}_{\mathrm{CH}} \quad=$ Relative disposal cost factor for liquid contact-handled waste [unitless] 
$\mathrm{VL}_{\mathrm{CH}}=$ Volume of liquid contact-handled waste [length ${ }^{3}$ ]

$\mathrm{fS}_{\mathrm{CH}} \quad=$ Relative disposal cost factor for solid contact-handled waste [unitless]

$\mathrm{VS}_{\mathrm{CH}}=$ Volume of solid contact-handled waste [length $\left.{ }^{3}\right]$

\section{Environment, Health, and Safety Performance Index Calculation}

The EH\&S performance index presents a normalized basis for comparison of technologies' performance based on human and environmental health and safety issues. The data for this comparison come directly from information included in the technology dataset in Appendix C.

\section{Technology Implementation, Operation, and Maintenance Performance Index Calculation}

The technology implementation, operation, and maintenance performance index also presents a normalized basis for comparison of technologies' performance based on reliability issues. The data for this comparison come directly from information included in the technology dataset in Appendix $\mathrm{C}$ as well.

\section{Overall Performance Index Calculation}

The overall performance index, which is a normalized basis for comparison of technologies, is calculated using Equation 7. Through adjustment of priority values in the Priority Ranking setup screen of the SDA software, the user defines the relative importance of each of the intermediate performance indices. As a result, Equation 7 includes a weighted sum of the above intermediate performance indices normalized from 0 to 1 , with 1 being the most desirable technology based on the stated needs and scenario of the user.

$$
P I_{\text {Overall }}=\frac{P_{S R} \cdot P I_{S R}+P_{T} \cdot P I_{T}+P_{W D} \cdot P I_{W D}+P_{E S H} \cdot P I_{E S H}+P_{M} \cdot P I_{M}}{\max \left(P_{S R} \cdot P I_{S R}+P_{T} \cdot P I_{T}+P_{W D} \cdot P I_{W D}+P_{E S H} \cdot P I_{E S H}+P_{M} \cdot P I_{M}\right)}
$$

Where:

$\mathrm{PI}_{\text {Overall }}=$ Overall performance index [unitless]

$\mathrm{P}_{\mathrm{SR}} \quad=$ Surface removal priority factor [unitless]

$\mathrm{PI}_{\mathrm{SR}} \quad=$ Surface removal performance index [unitless]

$\mathrm{P}_{\mathrm{T}} \quad=$ Transportation priority factor [unitless]

$\mathrm{PI}_{\mathrm{T}} \quad=$ Transportation performance index [unitless]

$\mathrm{P}_{\mathrm{WD}} \quad=$ Waste disposal priority factor [unitless]

$\mathrm{PI}_{\mathrm{WD}} \quad=$ Waste disposal performance index [unitless]

$\mathrm{P}_{\mathrm{ESH}}=$ Environment, health, and safety priority factor [unitless]

$\mathrm{PI}_{\mathrm{ESH}}=$ Environment, health, and safety performance index [unitless]

$\mathrm{P}_{\mathrm{M}} \quad=$ Technology implementation, operation, and maintenance priority factor [unitless]

$\mathrm{PI}_{\mathrm{M}} \quad=$ Technology implementation, operation, and maintenance performance index [unitless] 


\section{Sensitivity Analyses}

Several sensitivity analyses were performed during the course of this work to evaluate the software implementation of the logic depicted in the flowcharts of the model design tree and to verify the equations in Appendix E.

Table 1 lists the values for one of the final sets of test scenarios used to evaluate the software. Comparative graphs of the performance indices resulting from some of these scenarios are included in Appendix F.

\section{Task 5 - Design of Model Data Structure}

The SDA software has as one of its key components an extendable dataset of surface decontamination technology performance data. The technology dataset is designed to incorporate all of the information unique to each surface decontamination technique necessary to apply the SDA model. Each technology dataset record contains the following fields:

- Technology name

- Description, including type of process (e.g., physical, chemical, effects on the substrate)

- Applicable substrates (concrete, steel, or both)

- Aggressive surface removal capabilities

- Production rate

- Operating cost

- Volume, phase (solid or liquid), and density of secondary waste

- Thickness of cleaning depth

- Number of workers necessary for operation

- Number of passes needed to achieve $100 \%$ surface coating removal

- Vertical surface-cleaning ability

- Ability to clean hard-to-reach areas

- On-line analysis capabilities

- EH\&S factor

- Implementation state, operation, and maintenance factor

- Technology development stage

- Whether labor charge is included in operating costs

- Comparative setup factors 
TABLE 1

Surface Decontamination Assistant Model Test Scenarios

\begin{tabular}{|c|c|c|c|c|c|c|c|c|c|}
\hline Scenario & Total Area & $\begin{array}{c}\% \text { Hard to } \\
\text { Reach }\end{array}$ & $\begin{array}{l}\text { Thickness of } \\
\text { Coating, in. }\end{array}$ & $\begin{array}{l}\text { Substrate } \\
\text { Removal } \\
\text { Depth, in. }\end{array}$ & $\begin{array}{l}\text { On-Site } \\
\text { Separation }\end{array}$ & $\begin{array}{c}\% \text { Construction } \\
\text { and Demolition } \\
\text { Waste }\end{array}$ & $\begin{array}{l}\% \text { Contact } \\
\text { Handled } \\
\text { Waste }\end{array}$ & $\begin{array}{l}\% \text { Area Remote } \\
\text { Handled Waste }\end{array}$ & $\begin{array}{c}\text { On-Site Storage } \\
\text { of solids }\end{array}$ \\
\hline 1 & 3000 & 0 & 0.5 & 0 & No & 20 & 60 & 20 & No \\
\hline 2 & 3000 & 0 & 0.05 & 6 & No & 20 & 60 & 20 & No \\
\hline 3 & 3000 & 0 & 0.1 & 0 & No & 20 & 60 & 20 & No \\
\hline 4 & 3000 & 0 & 0.1 & 6 & No & 20 & 60 & 20 & Yes \\
\hline 5 & 3000 & 0 & 0.95 & 0 & No & 20 & 60 & 20 & No \\
\hline 6 & 3000 & 0 & 0.95 & 6 & No & 0 & 100 & 0 & No \\
\hline 7 & 3000 & 40 & 0.05 & 0 & No & 20 & 60 & 20 & No \\
\hline 8 & 3000 & 40 & 0.05 & 6 & Yes & 20 & 60 & 20 & No \\
\hline 9 & 3000 & 40 & 0.95 & 0 & No & 20 & 60 & 20 & No \\
\hline 10 & 3000 & 40 & 0.95 & 6 & No & 20 & 60 & 20 & No \\
\hline 11 & 20000 & 0 & 0.05 & 0 & Yes & 0 & 100 & 0 & No \\
\hline $11 a$ & 20000 & 0 & 0.05 & 0 & No & 20 & 60 & 20 & No \\
\hline 12 & 20000 & 0 & 0.05 & 6 & No & 20 & 60 & 20 & No \\
\hline 13 & 20000 & 0 & 0.95 & 0 & No & 20 & 60 & 20 & No \\
\hline 14 & 20000 & 0 & 0.95 & 6 & No & 20 & 60 & 20 & Yes \\
\hline $14 a$ & 20000 & 0 & 0.95 & 6 & Yes & 20 & 60 & 20 & Yes \\
\hline 15 & 20000 & 40 & 0.05 & 0 & Yes & 20 & 60 & 20 & No \\
\hline 16 & 20000 & 40 & 0.05 & 6 & Yes & 20 & 60 & 20 & No \\
\hline 17 & 20000 & 40 & 0.95 & 0 & Yes & 20 & 60 & 20 & No \\
\hline 18 & 20000 & 40 & 0.95 & 6 & Yes & 0 & 100 & 0 & No \\
\hline 19 & 20000 & 0 & 0.95 & 6 & No & 20 & 60 & 20 & No \\
\hline 20 & 20000 & 0 & 0.95 & 0 & Yes & 20 & 60 & 20 & No \\
\hline 21 & 20000 & 40 & 0.95 & 6 & No & 20 & 60 & 20 & Yes \\
\hline $21 a$ & 20000 & 40 & 0.95 & 6 & No & 20 & 60 & 20 & No \\
\hline 22 & 20000 & 40 & 0.1 & 0 & Yes & 20 & 60 & 20 & No \\
\hline
\end{tabular}


Appendix C contains a listing of the technology dataset. Information in the dataset includes verification of the data.

\section{Task 6 - PC Software Design and Coding}

The architecture of the SDA software is based on the major subsections illustrated in Figure 1.

The user interacts with the SDA software through a set of dialog boxes. The user is led through a series of input dialogs where the following aspects of the user-defined application scenario are entered:

1. Scenario summary description - site name, location of site, general substrate description, general contamination description, site activation date, modification date.

2. Detailed site description - surface type, substrate material, total area of the surface, area of hard-to-reach portions of the surface, thickness of surface coating, thickness of the substrate to be removed.

3. General contamination information - generic types of contamination.

4. Quantified contamination information - availability of on-site separation of liquids and solids, percentage distribution of surface area not contaminated by hazardous waste, area contaminated by $\mathrm{CH}$ waste, and area contaminated by $\mathrm{RH}$ waste.

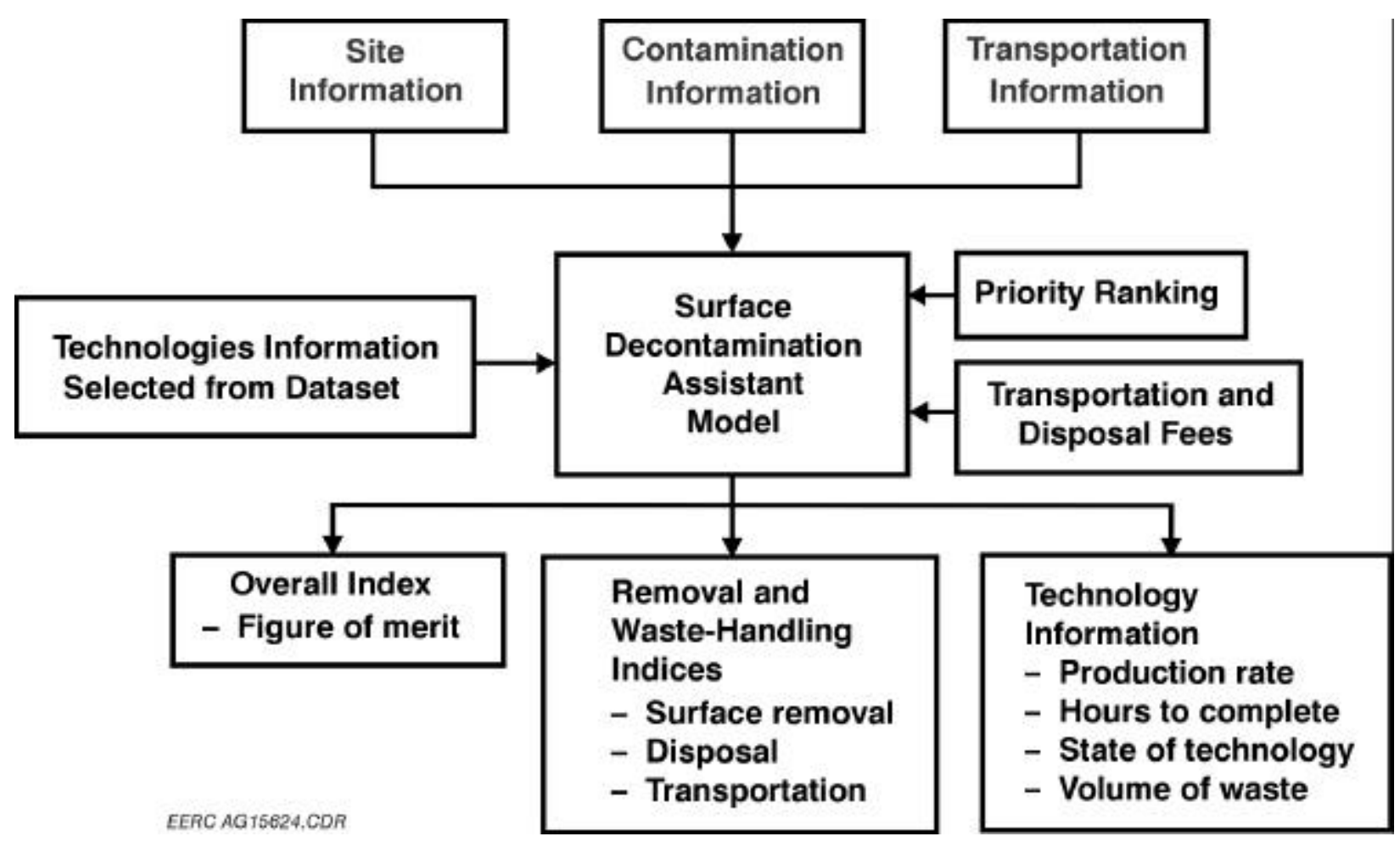

Figure 1. Surface Decontamination Assistant software architecture. 
5. Transportation information - off-site and on-site transportation distances for three types of waste, nonhazardous waste, transportation distance, style of transport, storage of solids on- or off-site.

6. Technology selection - pick technologies to evaluate using the model.

7. Setup inputs - transportation fees, waste disposal fees, priority rankings of the performance categories.

A detailed description of the program structure and illustrations for each of the dialog boxes presented by the program are in Appendix G. In addition, Appendix G is designed to serve as a stand-alone manual for using the software.

\section{CONCLUSIONS}

The SDA software program that was developed during this project is a useful tool for selecting appropriate surface decontamination techniques to remediate hazardous and nonhazardous surfaces. The software includes performance data for decontamination technologies currently available and in various stages of development. The information gathered through the literature search served as the basis for the dataset and development of the decision tree from which the model data structures and PC software were designed. Implementation of the model into computer code produced a program that is both effective and user-friendly. Careful examination and thoughtful analysis of sensitivity data indicated discrepancies in the model design and coding which have since been eliminated. The result is a well-researched and executed vehicle for comparing surface decontamination techniques as applied to user-defined scenarios.

Since the goal of the software tool is to provide a guide by which the user can compare and rate various surface decontamination technologies, the performance data from the technologies must be comparable. Great effort was made to obtain the most reliable data on a comparable basis and to verify each datum included in the dataset. The quality, precision, consistency, and availability of data remain issues limiting the accuracy of any information-based tool. Performance data for individual technologies varied in consistency and quality; thus the data set is the weakest element in the final product. The SDA design, however, allows updated performance data to be easily incorporated into the software. The data set can be amended as better data become available without changing other components. The SDA is an excellent tool for surface decontamination technology comparisons. 


\section{REFERENCES}

1. Archibald, K.E. “Concrete Decontamination Scoping Tests," U.S. Department of Energy Idaho National Engineering Laboratory: Idaho Falls, ID, 1995; pp 1-19.

2. Ebadian, M.A.; Lagos, L.E.; Boudreaux, J.F.; Clark, T.R.; Miller, L.K. "Analysis of Potential Surface Blasting Decontamination Technologies for Structural Steel," Fernald Environmental Restoration Management Corporation: Cincinnati, OH, 1995; pp 1-41.

3. Grieco, S.A.; Neubauer, E.D.; Rhea, J.R. "Removal and Treatment of Radioactive, Organochlorine, and Heavy Metal Contaminants from Solid Surfaces," In Radioactive and Hazardous Surface Decontamination Utilizing Soda Blasting; O'Brien and Gere Technical Services, Inc.: East Syracruse, NY, 1995; pp 1-10.

4. White, T.L.; Foster, D., Jr.; Wilson, C.T.; Schaich, C.R. "Phase 2 Microwave Concrete Decontamination Results," DE95010212CT; In Waste Management '95: Working Towards a Cleaner Environment; U.S. Department of Energy: Oak Ridge, TN, 1995.

5. Corleto, P.; Guidotti, M.; Ragazzo, G. "A Microwave System to Scarify Concrete Surfaces Upgrading and Testing," In Proceedings of the International Topical Meeting on Nuclear and Hazardous Waste Management Spectrum '94; U.S. Department of Energy American Nuclear Society, Inc.: La Grange Park, IL, 1994; pp 369-373.

6. Halter, J.M.; Sullivan, R.G. "Techniques for Removing Contaminated Concrete Surfaces," Environmental Decontamination 1979, 185-194.

7. Halter, J.M.; Sullivan, R.G. "Contaminated Concrete Surface Layer Removal," EY-76-C-061830, Reprinted from Surface Contamination; Mittal, K.L., Ed.; U.S. Department of Energy-Plenum Publishing Corp.: New York, NY, 1979; Vol. 1, pp 443-455.

8. Barbier, M.M.; Chester, C.V. "Decontamination of Large Horizontal Concrete Surfaces Outdoors," W-7405-eng-26; U.S. Department of Energy, pp 1-26. 
APPENDIX A

\section{SURFACE DECONTAMINATION DECISION TREE}




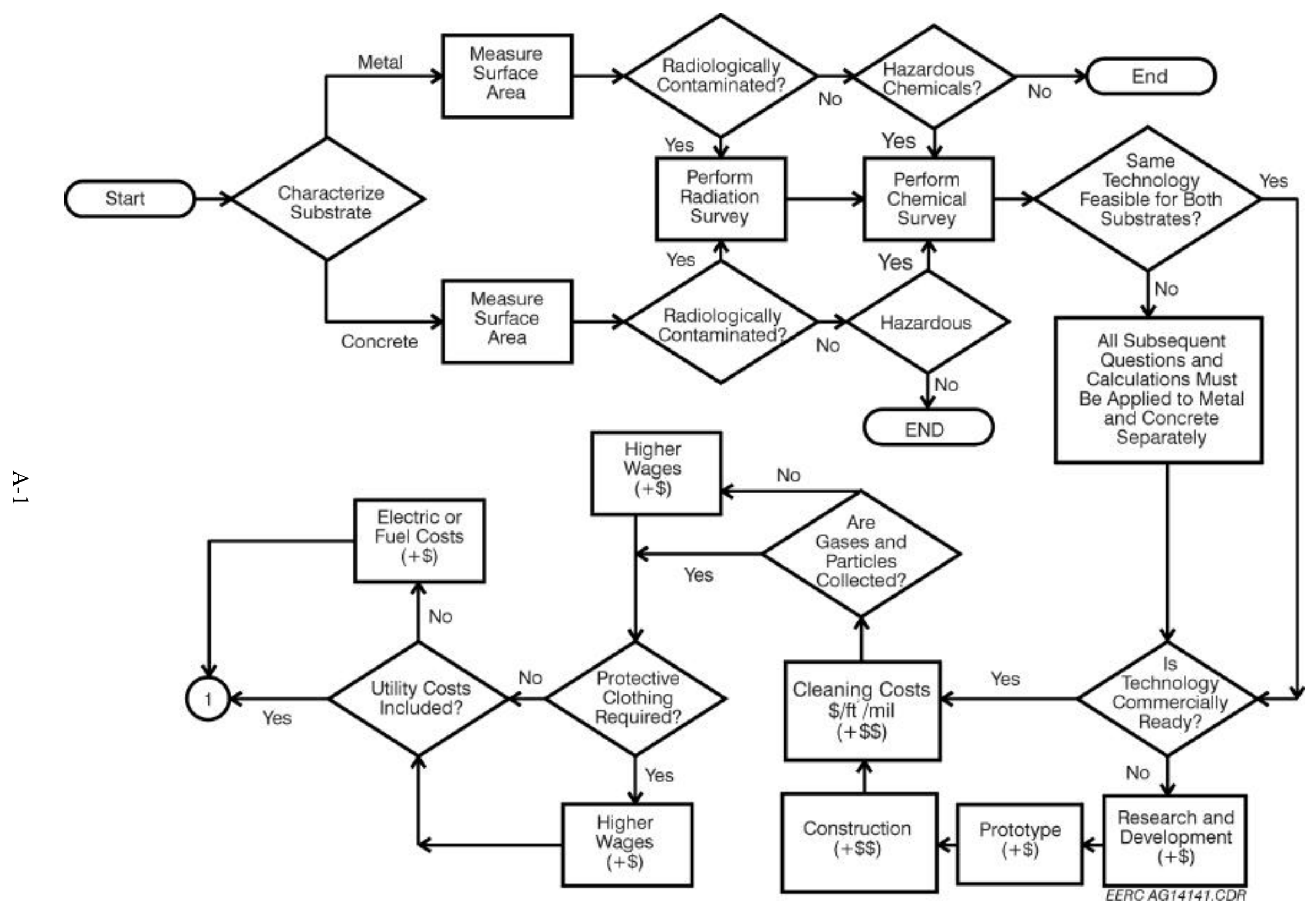

Figure A1. Surface decontamination decision tree, Sheet 1. 


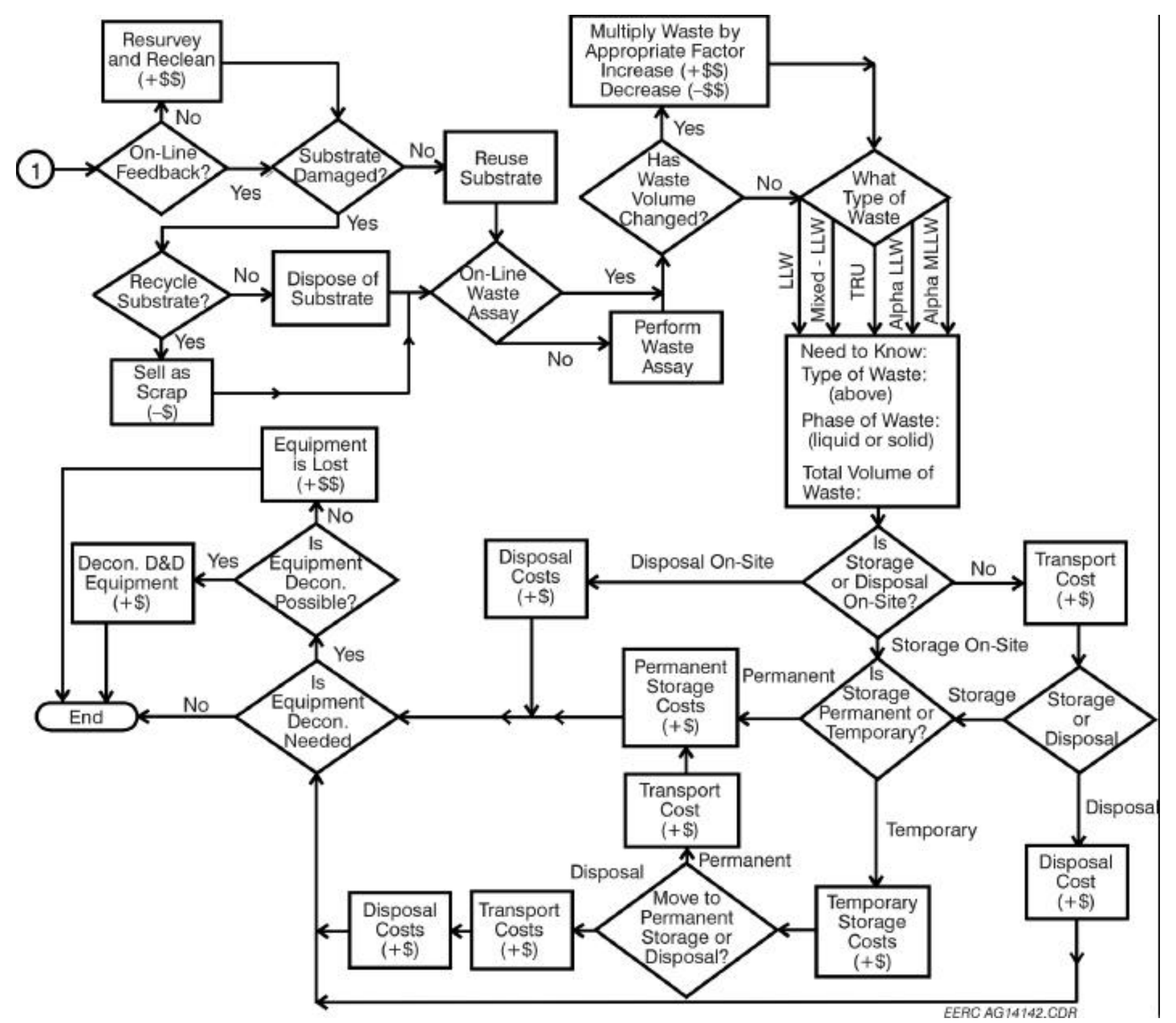

Figure A2. Surface decontamination decision tree, Sheet 2. 


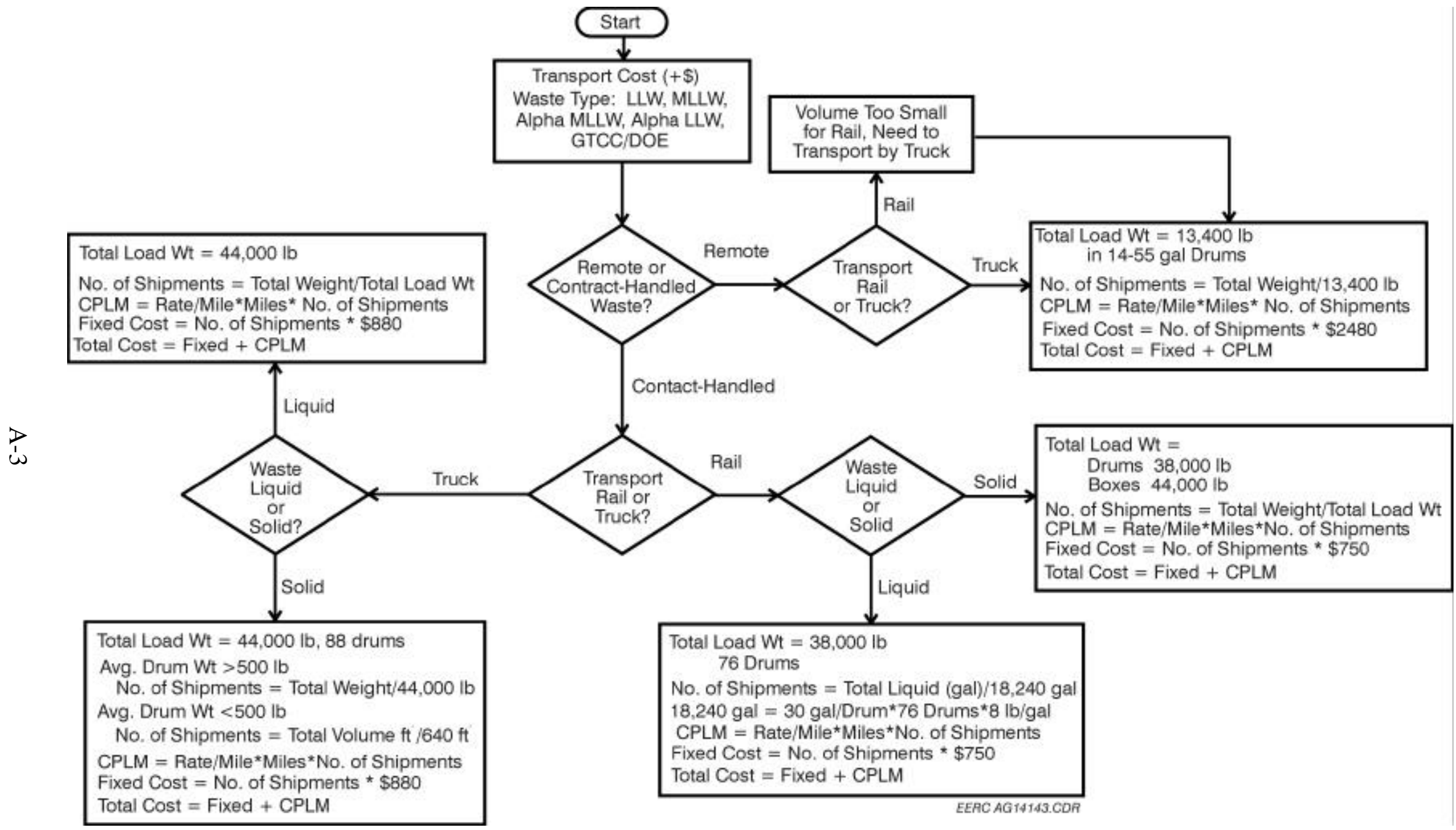

Figure A3. Surface decontamination decision tree, Sheet 3. 
APPENDIX B

\section{LITERATURE DATABASE}




\section{LITERATURE DATABASE}

1. U.S. Department of Energy. "Mixed Waste Focus Area Integrated Technical Baseline Report Phase I," DOE/ID-10524; U.S. Department of Energy Idaho National Engineering Laboratory, 1996; Vol. 2, pp 1-384.

2. U.S. Department of Energy. "Technology Assessment: Laser Technologies for Decontamination and Decommissioning of Nuclear Facilities," Decontamination and Decommissioning Focus Area, Morgantown Energy Technology Center, 1996; pp 1-16.

3. Ayers, K.W.; Boren, J.K.; Stephen, A.; Parker, F.L. "Reuse of Concrete from Contaminated Structures. Part 1: Economic Analysis of the Feasibility of Recycling Contaminated Concrete," DE-FG05-94OR22343; Department of Civil and Environmental Engineering, Vanderbilt University: Nashville, TN, 1996; pp 14-21.

4. Bierschbach, M.C. "Estimating Boiling Water Reactor Decommissioning Costs," NUREG/CR-6270; U.S. NRC Pacific Northwest National Laboratory, 1996.

5. Darnell, G.R.; Larsen, M.M. "Existing LLW Treatment and Disposal Technology Offers 17to-1 Volume Reduction and Advanced Disposal at Low Cost," DE-AC07-761D01570; U.S. Department of Energy Idaho National Engineering Laboratory: Idaho Falls, ID, 1996; pp 15-21.

6. U.S. Department of Energy. "Evaluation of Radioactive Scrap Metal Recycling," ANL/EAD/TM-50; Environmental Assessment Division, Argonne National Laboratory, 1996.

7. Swanston, S.R.; Davis, M.; Janke, R.J. "Unit Decontamination and Dismantlement (D\&D) Costs," ANL/DIS/CP-87709; U.S. Department of Energy Argonne National Laboratory, 1996; pp 1-10.

8. Goodwill, M.E.; Lively, J.W.; Morris, R.L. "Radiological Decontamination, Survey, and Statistical Release Method for Vehicles," DE-AC04-86ID12584; U.S. Department of Energy, Grand Junction, CO, 1996; pp 1-12.

9. Kaelin, A.B. "Properly Engineer Lead Paint Removal Projects," Chemical Engineering Progress 1996, 92 (1), 50-55.

10. S.A. SAIC. Market Assessment Decontamination of Radioactivity - Contaminated Concrete; 1996.

11. U.S. Department of Energy. "Draft Waste Management Programmatic Environmental Impact Statement for Managing Treatment, Storage, and Disposal of Radioactive and Hazardous Waste," DOE/EIS-0200-D; Office of Environmental Management, 1995; Vol. 4, pp 1-469. 
12. U.S. Department of Energy. "Commercial Environmental Cleanup - The Products and Services Directory,” DOE/ID/12584-230; Grand Junction Projects Office, 1995; pp 1-1260.

13. Allen, L.; Pang, H.; Edelson, M.C. "Applications of Lasers to the Solution of Environmental Problems,” IS-M840; U.S. Department of Energy Ames Laboratory, 1995; pp 1-8.

14. Archibald, K.E. "Concrete Decontamination Scoping Tests," U.S. Department of Energy. Idaho National Engineering Laboratory: Idaho Falls, ID, 1995; pp 1-19.

15. Benson, C.E.; Parfitt, J.E.; Patton, B.D. "Decontamination of Surfaces by Blasting with Crystals of $\mathrm{H}_{2} \mathrm{O}$ and $\mathrm{CO}_{2}$," DE-AC05-84OR21400; U.S. Department of Energy: Oak Ridge, TN, 1995; pp 1-63.

16. Bierschbach, M.C. "Estimating Pressurized Water Reactor Decommissioning Costs," NUREG/CR-6054; Pacific Northwest Laboratory: Richland, WA, 1995; pp 1-150.

17. Boudreaux, J.F. "Comparative Analysis of Surface Decontamination Technologies for Standard Steel Shapes," U.S. Department of Energy Office of Environmental Restoration, pp 751-995.

18. Byrd, J.S. “An Intelligent Inspection and Survey Robot,” U.S. Department of Energy: Morgantown, WV, 1995; pp 299-304.

19. Conner, C.; Chamberlain, D.B.; Chen, L.; Vandegrift, G.F. "Equipment Decontamination: A Brief Survey of the DOE Complex," ANL-95/32; U.S. Department of Energy Argonne National Laboratory: Argonne, IL, 1995; pp 1-9.

20. Cook, E.; Quaranta, J. "Decontamination Systems Information and Research Program," U.S. Department of Energy: Morgantown, WV, 1995; pp 98-102.

21. Crystal, J.B. "Development Test Procedure for High Pressure Water Jet System," WHCSD-SNF-TC-004 for U.S. Department of Energy; Westinghouse Hanford Co.: Richland, WA, 1995; p 1-C-1.

22. Dickerson, K.S.; Wilson-Nichols, M.J.; Morris, M.I. "Contaminated Concrete: Occurrence and Emerging Technologies for DOE Decontamination," DOE/ORO/2034; U.S. Department of Energy Oak Ridge National Laboratory, 1995; pp 1-352.

23. Dickerson, K.S.; Ally, M.R.; Brown, C.H.; Wilson-Nichols, M.J.; Morris, M.I. "Demonstration Recommendations for Accelerated Testing of Concrete Decontamination Methods," ORNL/TM-13098, U.S. Department of Energy Oak Ridge National Laboratory, 1995; pp 1-70. 
24. Ebadian, M.A.; Lagos, L.E.; Boudreaux, J.F.; Clark, T.R.; Miller, L.K. "Analysis of Potential Surface Blasting Decontamination Technologies for Structural Steel," Fernald Environmental Restoration Management Corporation: Cincinnati, OH, 1995; pp 1-4.

25. Edelson, M.C.; Pang, H.; Ferguson, R.L. "A Laser-Based Solution to Industrial Decontamination Problems,” IS-M838; 1995; pp 1-10.

26. Feizollahi, F.; Shropshire, D.; Burton, D. "Waste Management Facilities Cost Information for Transportation of Radioactive and Hazardous Materials," DE96002295; U.S. Department of Energy: Idaho Falls, ID, 1995; pp 1-21.

27. Freiwald, J.G.; Freiwald, D.A. "Laser-Based Coatings Removal," U.S. Department of Energy: Morgantown, WV, 1995; pp 214-224.

28. Goldfarb, V.; Gannon, R. "Concrete Decontamination by Electro-Hydraulic Scabbling," U.S. Department of Energy: Morgantown, WV, 1995; pp 225-232.

29. Grieco, S.A.; Neubauer, E.D.; Rhea, J.R. "Removal and Treatment of Radioactive, Organochlorine, and Heavy Metal Contaminants from Solid Surfaces, In Radioactive and Hazardous Surface Decontamination Utilizing Soda Blasting; O'Brien \& Gere Technical Services, Inc.: East Syracuse, NY, 1995; pp 1-10.

30. Grieco, S.A.; Neubauer, E.D.; Rhea, J.R. "Removal and Treatment of Radioactive Contaminants," Nuclear Plant Journal 1995, 13 (4).

31. Griffin, T.P.; Johnston, J.E.; Payea, B.M.; Zeitoon, B.M. "Catalytic Extraction Processing of Contaminated Scrap Metal,” U.S. Department of Energy: Morgantown, WV, 1995; pp 137-155.

32. Haines, J.R.; Fisher, P.W.; Foster, C.A. "Solvent-Free Cleaning Using a Centrifugal Cryogenic Pellet Accelerator," Martin Marietta Energy Systems, 9504123-1; Innovative Concepts Technology Fair, U.S. Department of Energy Oak Ridge National Laboratory: Denver, CO, 1995; pp 1-5.

33. Hanulik, J., inventor; Deco-Hanulik, A.G., assignee. "Process for Decontaminating Radioactive Metal Surfaces," CAX No. 5386 078, 1995; 1882 503, 4508 641, 4587 043, 5008044 , and 5024805.

34. Konzek, G.J.; Smith, R.I.; Bierschback, M.C.; McDuffie, P.N. "Revised Analysis of Decommissioning for the Reference Pressurized Water Reactor Poser Station," NUREG/CR-5884 PNL-87, U.S. NRC Pacific Northwest Laboratory, 1995; pp 1-418.

35. Krupa, B. "Evaluation of Plant 7 Decontamination Methods," 1995. 
36. Lomasney, H. "Electrokinetic Decontamination of Concrete," U.S. Department of Energy: Morgantown, WV, 1995; pp 18-21.

37. MacArthur, D. "Alpha Detection for Decontamination and Decommissioning: Results and Possibilities," 1205, Environmental Remediation. U.S. Department of Energy: Denver, CO, 1995.

38. Moore, T. "Rising to the Challenge in Military-Site Cleanups," Environ. Eng. World 1995, 28-33.

39. Muth, T.R.; Shasteen, K.E.; Liby, A.L.; Mishra, B.; Olson, D.L.; Hradil, G. “Advanced Technologies for Decontamination and Conversion of Scrap Metal," U.S. Department of Energy: Morgantown, WV, 1995; pp 233-238.

40. Nichols, F. "Feasibility Analysis of Recycling Radioactive Scrap Steel,” DOE/ID/12735T38; U.S. Department of Energy Western Environmental Office, 1995; pp 1-191.

41. Nieves, L.A.; Chen, S.Y.; Kohout, E.J.; Nabelssi, B.; Tilbrook, R.W.; Wilson, S.E. "Evaluation of Radioactive Scrap Metal Recycling," ANL/EAD/TM-50; U.S. Department of Energy Argonne National Laboratory, 1995; pp 1-474.

42. O'Brien and Gere Technical Services. "Pilot-Scale Treatability Testing - Recycle, Reuse, and Disposal of Materials from Decontamination and Decommissioning Activities: Soda Blasting Demonstration," DOE/ORO-2032; U.S. Department of Energy Oak Ridge K-25 Site: Oak Ridge, TN, 1995.

43. Osborn, J. L.; Bares, C.; Thompson, B.R. "Mobile Worksystems for Decontamination and Dismantlement," U.S. Department of Energy: Morgantown, WV, 1995; pp 243-253.

44. Reisch, M.S. "Paints \& Coatings," C\&EN 1995, 30-31.

45. Resnick, A.M. "Remote Operated Vehicle with Carbon Dioxide Blasting (ROVCO2)," U.S. Department of Energy: Morgantown, WV 1995; pp 239-242.

46. Russ, W.R.; Valentine, J.D.; Chung, W. "Radiological Contamination Penetration Depth in Fernald Transite Panels,” FEMP/SUB-104 UC-271; U.S. Department of Energy Fernald Field Office: 1995 ; pp 1-8.

47. Shropshire, D.; Feizollahi, F. "Life Cycle Cost Estimation and Systems Analysis of Waste Management Facilities,” DE96001615; U.S. Department of Energy: Idaho Falls, ID, 1995; pp 12.

48. Smith, M.; Harris, J.G.; Moore-Mayne, S.; Mayes, S.R.; Naretto, C. "Review of Private Sector Treatment, Storage, and Disposal Capacity for Radioactive Waste," INEL-95/0020; U.S. Department of Energy Idaho National Engineering Laboratory, 1995; pp 1-73. 
49. Trovato, S.A.; Parry, J.O.; Monti, W.A.; Burger, J.M. "Decontaminating a Nuclear Power Plant," Mechanical Engineering 1995, 76-78.

50. "Long-Term Decontamination Engineering Study," WHC-SD-WM-ES-283; prepared for U.S. Department of Energy by Westinghouse Hanford Co.: Richland, WA; 1995; Vols. 1, 2, pp A-1-B-147.

51. White, T.L.; Foster, D.C., Jr.; Wilson, T.; Schaich, C.R. "Phase 2 Microwave Concrete Decontamination Results," DE95010212CT; In Waste Management '95: Working Towards a Cleaner Environment; U.S. Department of Energy: Oak Ridge, TN, 1995.

52. Worchester, S.A.; Twidwell, L.G.; Paolini, D.J.; Weldon, T.A.; Mizia, R.E. "Decontamination of Metals by Melt Refining/Slagging, An Annotated Biblography: Updata on Stainless Steel and Steel," INEL-95/0123; U.S. Department of Energy Idaho National Engineering Laboratory, 1995; pp 1-97.

53. "Escalation of Decommissioning Waste Disposal Costs at Low-Level Waste Burial Facilities," NUREG-1307, Report on Waste Burial Charges; U.S. Nuclear Regulatory Commission: Washington, DC. 1994; pp 1.1-4.1.

54. Aldridge, T.L.; Aldrich, L.K., II; Bowman, E.V. " $\mathrm{CO}_{2}$ Pellet Decontamination Technology at Westinghouse Hanford,” WHC-SA-2435; prepared for U.S. Department of Energy by Westinghouse Hanford Co.: Richland, WA., 1994; pp 1-15.

55. Bonem, M.W. "Economical Decontamination of Concrete and Metal Using the TechXtract Process." In Proceedings of the International Topical Meeting on Nuclear and Hazardous Waste Management - Spectrum '94; U.S. Department of Energy-American Nuclear Society, Inc.: La Grange Park, IL, 1994; Vol. 3, pp 2434-2438.

56. Corleto, P.; Guidotti, M.; Ragazzo, G. "A Microwave System to Scarify Concrete Surfaces Upgrading and Testing," In Proceedings of the International Topical Meeting on Nuclear and Hazardous Waste Management - Spectrum '94; U.S. Department of Energy-American Nuclear Society, Inc.: La Grange Park, IL, 1994; pp 369-373.

57. Erickson; T.E.; Musich; M.A.; Sondreal, E.A. et al. "Review of 'Reuse of Concrete from Contaminated Structures, Part 1: Economic Analysis of the Feasibility of Recycling Contaminated Concrete'," Prepared for Dr. Paul Hart, Decontamination \& Decommissioning Area Leader, DOE Federal Energy Technology Center by Energy \& Environmental Research Center, University of North Dakota, March 1995.

58. Demmer, R. "Testing and Evaluation of Eight Decontamination Chemicals," U.S. Department of Energy. WINCO-1228, Idaho National Engineering Laboratory. Westinghouse Idaho Nuclear Company, Inc.: Idaho Falls, ID, 1994; pp 1-12. 
59. Demmer, R.L.; Ferguson, R.L. "Testing and Evaluation of Light Ablation

Decontamination," U.S. Department of Energy Idaho National Engineering Laboratory: Idaho Falls, ID, 1994; pp 1-27.

60. Demmer, R.L. "Development of Simulated Contamination (SIMCON) and Miscellaneous Decontamination Scoping Tests," DEAC07841D12435; U.S. Department of EnergyWestinghouse Idaho Nuclear Company, Inc.: Idaho Falls, ID, 1994; pp 1-13.

61. Feizollahi, F.; Shropshire, D.; Burton, D. "Waste Management Facilities Cost Information for Transportation of Radioactive and Hazardous Materials," Revision 1. DE95002022; U.S. Department of Energy: San Francisco, CA, 1994; 203 p.

62. Feizollahi F.; Shropshire, D. "Waste Management Facilities Cost Information for Mixed Low-Level Waste," interim report DE95009458; U.S. Department of Energy: Idaho Falls, ID, 1994; pp 1-1-29-6.

63. Feizollahi, F.; Quapp, W.J.; Hempill, H.G.; Groffie, F.J. "Integrated Thermal Treatment System Study-Phase 1 Results," DE-AC07-761D01570; U.S. Department of Energy, 1994; pp. 1-167.

64. Gillis, P.J., Jr. "Radwaste Cost Savings \& Mixed Waste Volume Reduction Achieved with $\mathrm{CO}_{2}$ Decontamination - Actual Utility History," In Technology and Programs for Radioactive Waste Management and Environmental Restoration; Post, R.G., Ed.; 1994; Vol. 3, pp 1647-1649.

65. Hanulik, J. "Decofor and Decoconcrete New Metal and Concrete Decontamination Processes for Decommissioning," 1994 International Symposium on Decontamination \& Decommissioning.

66. Lomasney H.L.; Yachmenev, V. "Electrokinetic Decontamination of Concrete," In Proceedings of Opportunity '95 - Environmental Technology Through Small Business; Kothari, V.P., Ed.; U.S. Department of Energy Morgantown Energy Technology Center: Morgantown, WV, 1994; pp 190-191.

67. Moorthy, P.N.; Rao, U.R.K.; Venkateswaran, G.; Gokhale, A.S.; Yuvaraju, B.; Vinaykumar, C.K.; Wagh, P.M.; Kansara, H.M. "Evaluation of Lomi and Citrate Formulations for the Decontamination of the Clean Up System Surfaces of Tarapur Atomic Power Station,” 1994 International Symposium on Decontamination \& Decommissioning; U.S. Department of Energy BWRS, 1994.

68. Simmons, M. "Decontamination of Radioactive Concrete: A Permanent Solution That's RCRA Friendly," Radwaste Magazine 1994 1, 25-29. 
69. Tripp, J.L. "Criteria and Evaluation of Three Decontamination Techniques," WINCO-1187; prepared for U.S. Department of Energy by Westinghouse Idaho Nuclear Company Inc.: Idaho Falls, ID, 1994; pp. 1-A-12.

70. Tripp, J.L. "Criteria and Evaluation of Three Decontamination Techniques," DEAC07841D12435; prepared for U.S. Department of Energy by Westinghouse Idaho Nuclear Company, Inc.: Idaho Falls, ID, 1994; pp 1-11.

71. Radiological Control Manual; DE93 013925, Lawrence Livermore Laboratory: Berkeley, CA, 1993; pp 1-21.

72. "Technology and Programs for Radioactive Waste Management and Environmental Restoration,' In WM'93, Waste Processing, Transportation, Storage and Disposal, Technical Programs and Public Education; Post, R.G.; Wacks, M.E., Eds.; U.S. Department of Energy: Tucson, AZ, 1993; Vols. 1 and 2.

73. Benda, G.A. "Commercial Experience in Treating U.S. Department of Energy Mixed Waste," In High Level Radioactive Waste and Spent Fuel Management; Ahlstroem, P.E.; Chapman, C.C.; Kohout, R.; Marek. J., Eds.; The American Society of Mechanical Engineers: New York, NY, 1993; pp 385-390.

74. Berg H.P.; Debski, H.J. “Cost Analysis of German Waste Repositories,” In High Level Radioactive Waste and Spent Fuel Management; Ahlstroem, P.E.; Chapman, C.C.; Kohout, R.; Marek. J., Eds.; The American Society of Mechanical Engineers: New York, NY, 1993; pp 809-814.

75. Bonem, M.W.; Borah, R.E.; Rathke, S.E. "Extraction of Contaminants from Porous Surfaces - Case History," Meeting the Challenge - ER '93 Environmental Remediation Conference; U.S. Department of Energy, 1993; Vol. 2, pp 1009-1011.

76. Bossart, S.J.; Moore, J. "Innovative Technologies for Recycling Contaminated Concrete and Scrap Metal," Meeting the Challenge - ER '93 Environmental Remediation Conference; U.S. Department of Energy, 1993; Vol. 2, pp 335-338.

77. Cannon, N.S.; Flesher, D.J. "Lasers for the Radioactive Decontamination of Concrete," In Proceedings of the International Conference on Lasers and Applications; DE94003468 CT, U.S. Department of Energy: Richland, WA, 1993.

78. Christ, B.G.; Wehner, E.L. "Project Specific Selection of Decommissioning Techniques," In High Level Radioactive Waste and Spent Fuel Management; Ahlstroem, P.E.; Chapman, C.C.; Kohout, R.; Marek, J., Eds.; The American Society of Mechanical Engineers: New York, NY, 1993; pp 189-192. 
79. Closs, J.W. "Decommissioning Experience: One-Piece Removal and Transport of a LWR Pressure Vessel and Internals," In High Level Radioactive Waste and Spent Fuel Management; Ahlstroem, P.E.; Chapman, C.C.; Kohout, R.; Marek, J., Eds.; The American Society of Mechanical Engineers: New York, NY, 1993; pp 105-109.

80. Corleto, P.; Guidotti, M.; Petagna, E.; Ragazzo, G. "A Microwave System to Scarify Concrete Surfaces: Development and Testing," In High Level Radioactive Waste and Spent Fuel Management; Ahlstroem, P.E.; Chapman, C.C.; Kohout, R.; Marek, J., Eds.; The American Society of Mechanical Engineers: New York, NY, 1993; pp 439-444.

81. Feizollahi F.; Shropshire, D. "Waste Management Facilities Cost Information Report for Greater-Than-Class C and DOE Equivalent Special Case Waste," DE94010770; U.S. Department of Energy: Idaho Falls, ID, 1993; pp 1-144.

82. Ferguson, R.L. "Liquid Abrasive Grit Blasting Literature Search and Decontamination Scoping Tests Report,” WINCO-1163; U.S. Department of Energy Idaho National Engineering Laboratory and Westinghouse Idaho Nuclear Company, Inc.: Idaho Falls, Idaho, 1993; pp 1-A-7.

83. Foster, D. "U.S. DOE Researchers Demonstrate Use of Microwaves to Decontaminate Concrete," D\&D Technologies 1993, 1, 15-16.

84. Fujiki K.; Nakamura, H. "Current Studies on the Decommissioning Materials Recycling at Japan Atomic Energy Research Institute,' In High Level Radioactive Waste and Spent Fuel Management; Ahlstroem, P.E.; Chapman, C.C.; Kohout, R.; Marek, J., Eds.; The American Society of Mechanical Engineers: New York, NY, 1993; pp 321-327.

85. Guthrie, W.S. "Foam Technology as a Decontamination/Waste Minimization Tool," DOE-Westinghouse, 1993; pp 243-248.

86. Ishikura, T.; Onozawa, T.T.; Onozawa, H.; Oshtsuka, H.; Ishigure, K. "Development of Decontamination Techniques for Decommissioning Commercial Nuclear Power Plants," In Ahlstroem, P.E.; Chapman, C.C.; Kohout, R.; Marek, J., Eds.; 2, High Level Radioactive Waste and Spent Fuel Management; The American Society of Mechanical Engineers: New York, NY, 1993; pp 295-300.

87. Johnso, S.V.; Mayberry, J.J. "Management Approaches for Environmental Restoration at the U.S. Department of Energy Weapons Complex, Savannah River Site: A Case Study," In Ahlstroem, P.E.; Chapman, C.C.; Kohout, R.; Marek, J., Eds.; 2, High Level Radioactive Waste and Spent Fuel Management; The American Society of Mechanical Engineers: New York, NY, 1993; pp 349-351. 
88. Long, F.G.; Ward, R.D.; McNicholas, P.; Albers, R.W.; Zaccai, H.; Tsyplenkov, V. "Assessment and Comparison of Waste Management Costs for Nuclear and Fossil Energy Sources,” In Ahlstroem, P.E.; Chapman, C.C.; Kohout, R.; Marek. J., Eds.; 2, High Level Radioactive Waste and Spent Fuel Management; The American Society of Mechanical Engineers: New York, NY, 1993; pp 815-823.

89. Majersky, D.; Solcanyi, M.; Prazska, M. "Recent Trends in the Area of the Decontamination of Nuclear Power Plants in the Slovak Republic and in the Czech Republic," In Ahlstroem, P.E.; Chapman, C.C.; Kohout, R.; Marek, J., Eds.; 2, High Level Radioactive Waste and Spent Fuel Management; The American Society of Mechanical Engineers: New York, NY, 1993; pp 301-306.

90. Mantega, F.; Sanson, F.; Garofalo, A.; Vitiello, T., "Garitta Project: An Example of Conditioning of Large Dimensions Irradiated Components," In Ahlstroem, P.E.; Chapman, C.C.; Kohout, R.; Marek, J., Eds.; 2, High Level Radioactive Waste and Spent Fuel Management; The American Society of Mechanical Engineers: New York, NY, 1993; pp 445-454.

91. Panciatici, G.; Belfiore, A.; Poggianti, M. "Attapulgite, A Decontaminating Medium, Research Tool in the Radioprotection Field," In Ahlstroem, P.E.; Chapman, C.C.; Kohout, R.; Marek, J., Eds.; 2, High Level Radioactive Waste and Spent Fuel Management; The American Society of Mechanical Engineers: New York, NY 1993; pp 313-320.

92. Pang, H.M.; Edelson, M.C.; Demmer, R. "Metal Decontamination Using High Power Lasers," 1 \& 2, Meeting the Challenge-ER '93 - Environmental Remediation Conference; DOE, 1993; Vol. 2, pp 999-1004.

93. Pickett, J.B.; England, J.L.; Martin, H.L. Life Cycle Cost Analysis Changes Mixed Waste Treatment Program at the Savannah River Site; Conf 9303105, DOE-Westinghouse Savannah River Co.: Aiken, SC, 1993.

94. Santiago J.L.; Sanchez, M. "Decommissioning and Waste Disposal Methods for an Uranium Mill Facility in Spain,” In Ahlstroem, P.E.; Chapman, C.C.; Kohout, R.; Marek, J., Eds.; 2, High Level Radioactive Waste and Spent Fuel Management; The American Society of Mechanical Engineers: New York, NY, 1993; pp 193-197.

95. Sebastian R.L.; Beck, B.G. inventors. Coleman Research Co. assignee. "Integrated Apparatus for Mapping and Characterizing the Chemical Composition of Surfaces," VA. No. 5416321, 437220, 1993.

96. Sleeman, R.C. "Update of Lessons Learned from Cleanup Projects at Oak Ridge," Ahlstroem, P.E.; Chapman, C.C.; Kohout, R.; Marek., J., Eds.; 2, High Level Radioactive Waste and Spent Fuel Management; The American Society of Mechanical Engineers: New York, NY, 1993; pp 333-335. 
97. Vovk, I.F.; Movchan, N.P.; Fedorenko, Y.G.; Shpigun, A.A.; Zlobenko, B.P. "Research on Cleanup of Buildings and Structures in Urban Areas of Ukraine Affected by the Accident at the Chernobyl NPP," In Ahlstroem, P.E.; Chapman, C.C.; Kohout, R.; Marek, J., Eds.; 2, High Level Radioactive Waste and Spent Fuel Management; The American Society of Mechanical Engineers: New York, NY, 1993; pp 225-227.

98. Wei, T.; Hsieh, J. "The Experiences of Using Ultrahigh-Pressure Waterjet to Decontaminate the Nuclear Facilities at Iner," In Ahlstroem, P.E.; Chapman, C.C.; Kohout, R.; Marek, J., Eds.; 2, High Level Radioactive Waste and Spent Fuel Management; The American Society of Mechanical Engineers: New York, NY, 1993; pp 433-437.

99. Yanagihara, S.; Itoh, S.; Shiraishi, K. "Systems Engineering for Decommissioning the Japan Power Demonstration Reactor (JPDR) - A Study on Characteristics of Decommissioning Waste," In Ahlstroem, P.E.; Chapman, C.C.; Kohout, R.; Marek, J., Eds.; 2, High Level Radioactive Waste and Spent Fuel Management; The American Society of Mechanical Engineers: New York, NY, 1993; pp 423-431.

100. Feizollahi F.; Shropshire, D. "Waste Management Facilities Cost Information Estimating Data," U.S. DOE DE95009462, Idaho Falls, ID, 1992, 319 p.

101. Jennings, H.T., inventor. British Nuclear Fuels Plc, assignee. "Method of Decontaminating a Cementitious Surface," Warrington, GBX. No. 5414196, 9616632, 1992.

102. Schlueter R.; Schafer, J.J. "Low-Level and Transuranic Waste Transportation, Disposal, and Facility Decommissioning Cost Sensitivity Analysis," EGG-WTD--10092, U.S. DOE Idaho National Engineering Laboratory, Idaho Falls, ID, 1992; pp 1-23.

103. Angus, M.J.; Hunter, S.R.; Ketchen, J. "Classification of Contaminated and NeutronActivated Concretes from Nuclear Facilities Prior to Their Decontamination or Decommissioning 2," 1990; Vol. 1, pp 229-234.

104. Bullard C.W.; Weger, H.T.; "LLRW Disposal: Economies of Scale and Waste-Type Segregation," Energy Systems and Policy 1990, 14, 227-236.

105. Gugan, M.A.; Sanders, M.J.; Collett, K.F. "Wet Abrasive Particle Impact Cleaning as a Nuclear Decontamination Technique," In Proceedings of the International Topical Meeting on Nuclear and Hazardous Waste Management Spectrum '90; American Nuclear Society, Inc.; La Grange Park, IL, 1990; pp 269-271.

106. Konzek, G.J.; Smith, R.I. “Technology, Safety and Costs of Decommissioning a Reference Boiling Water Reactor Power Station - Comparison of Two Decommissioning Cost Estimates Developed for the Same Commercial Nuclear Reactor Power Station," NUREG/CR-0672, Pacific Northwest Laboratory, Richland, WA, 1990; pp 1-59. 
107. Zaccai, H. "Evaluation of Storage and Disposal Costs for Conditioned Radioactive Waste in Several European Countries," EUR-12871, Commission of the European Communities, Luxembourg, 1990; pp 1-45.

108. Nuclear Waste - DOE's Method for Assigning Defense Waste Disposal Costs Complies with NWPA B-202377, 1989; pp 1-31.

109. Analysis of the Total System Life Cycle Cost for the Civilian Radioactive Waste Management Program; DOE/RW-0236, U.S. DOE Office of Civilian Radioactive Waste Management, Washington, DC, 1989; pp 1-1-9-7.

110. Bealby, J. “Optimization of Treatment, Storage and Disposal Strategies for (Unconditioned and Conditioned) Radioactive Waste," DOE-RW-89.063, DOE, London (United Kingdom), 1989; pp 1-27.

111. Chang, S.Y.; Rivera, A.L. "Theory and Evidence of Economies of Scale in the Development of Waste Management Systems," Presented at the U.S. DOE Model Conference, Oak Ridge, TN, Oct. 2-6, 1989; 8910193--2, 1989; pp 1-52.

112. Morillon, C.; Routier, J.F.; Pilot, G. "Thermal Techniques for Surface Concrete Decontamination," Decommissioning of Nuclear Installations; Proceedings of the 1989 International Conference; Elsevier Applied Science: Barking, United Kingdom, 1989; pp 553-563.

113. Pick, M.E. "PWR Oxide Characterisation/Surface Finish Improvement and Development of Decontamination Processes for Gas and Water Cooled Reactors," Decontamination and Decommissioning of Nuclear Facilities-Results of a Co-ordinated Research Programme, Phase II: 1989-1993; IAEA, 1989; pp 185-192.

114. Collins, H.E.; Leach, E.W. “TAM-D3: Boiling Water Reactor Recirculation Pipe Replacement: Radiological Challenges, Innovative Solutions, and Long-Term Plant Impact," 32nd Annual Meeting of the Health Physics Society, 1987; Vol. 52, Supplement 1.

115. Distenfeld, C.H.; Brosey, B.H.; Babel, P.J. ?TAM-D4: A Collimated Surface Monitor for Estimating Activity Absorbed in Concrete Walls," 32nd Annual Meeting of the Health Physics Society, 1987; Vol. 52, supplement 1.

116. Yasunaka, H.; Shibamoto, M.; Sukegawa, T.; Yamate, T.; Tanaka, M. "Microwave Decontaminator for Concrete Surface Decontamination in JPDR," In Tarcza, G.A., Ed.; 2, No. DE87012822, Proceedings of the 1987 International Decommissioning Symposium; DOE-Westinghouse Hanford Co.: Richland, WA., 1987; Vol 2, pp 109-116.

117. Elder, H.K. “Technology, Safety and Costs of Decommissioning Reference Nuclear Fuel Cycle Facilities," NUREG/CR-4519, Pacific Northwest Laboratory, Richland, WA, 1986; pp 1-22. 
118. United States Accounting Office. Nuclear Waste - Cost of DOE's Proposed Monitored Retrievable Storage Facility B-202377, 1986, pp 1-31.

119. McIsaac, C.V.; Davis, C.M.; Horan, J.T.; Keefer, D.G. "Results of Surface Activity and Radiation Field Measurements Made During Surface Decontamination Experiments Conducted at TMI-2," In Huebner, M.F., Ed.; Proceedings of the American Nuclear Society Meeting on Fission-Product Behavior and Source Term Research; DOE, 1985; pp 1-17.

120. Pavelek, II, M.D.; Carmel, P.G. "Volume Reduction of Contaminated Concrete Shield Slabs Through Surface Removal," In Post, R.G. Ed.; 2, Waste Management '85-Waste Isolation in the U.S. Technical Programs and Public Education-Waste Policies and Programs, LowLevel Waste. DOE, 1985; Vol. 2, pp 303-307.

121. Kuriyama, O.; Koyama, T.; Kikuchi, M. "Decontamination of Radioactive Metal Surfaces by Plasma Arc Gouging,” Nuclear Technology 1983, 61, 93-99.

122. Galecki, G.; Vickers, G.W. "The Development of Ice-Blasting for Surface Cleaning 6th International Symposium on Jet Cutting Technology," BHRA Fluid Engineering: Bedform, England, 1982; pp 59-79.

123. Halter, J.M.; Sullivan, R.G.; Bevan, J.L. "Surface Concrete Decontamination Equipment Developed by Pacific Northwest Laboratory," DEAC0676RL01830, U.S. DOE Pacific Northwest Laboratory, Richland, WA, 1982; pp 1-D.1.

124. McCoy, M.W.; Allen, R.P.; Fetrow, L.K.; Hazelton, R.F. "Vibratory Finishing for Decontamination - Pilot Scale Operation,” In Blasewitz, A.G.; Davis, J.M.; Smith. M.R, Eds.; The Treatment and Handling of Radioactive Wastes; Battelle Press \& Springer/Verlag: Columbus \& NY, 1982; pp 109-113.

125. Kennedy, W.E., Jr.; Watson, E.C.; Murphy, D.W.; Harrer, B.J.; Harty, R.; Aldrich, J.M. “A Review of Removable Surface Contamination on Radioactive Materials Transportation Containers," NUREG/CR-1858, Pacific Northwest Laboratory, Richland, WA, 1981; pp 1.1-6.2.

126. Cox E.J.; Garde, R. "Decontamination of Concrete Surfaces at the Los Alamos Scientific Laboratory," 1980.

127. Arrowsmith H.W.; Allen, R.P. "New Decontamination Techniques for Exposure Reduction 2," U.S. Department of Energy Environmental Control Symposium, DOE, 1979; Vol. 3, pp 183-206.

128. Clarke J.H.; Dippel, T. Manual on Decontamination of Surfaces, Safety Series; International Atomic Energy Agency: Vienna, Austria, 1979; Vol. 48, pp 1-44. 
129. Halter J.M.; Sullivan, R.G. "Techniques for Removing Contaminated Concrete Surfaces," Environmental Decontamination; 1979; pp 185-194.

130. Halter J.M.; Sullivan, R.G. "Contaminated Concrete Surface Layer Removal," In Mittal, K.L., Ed.; EY-76-C-06-1830, Reprinted from Surface Contamination, DOE-Plenum Publishing Corp.: New York, NY, 1979; Vol. 1, pp 443-455.

131. Kunze, S. "Waste-Compatible Cleansers for Elimination of Surface Contaminations," Kerntechnik 1979, 34, 147-150.

132. Barbier M.M.; Chester, C.V. "Decontamination of Large Horizontal Concrete Surfaces Outdoors," W-7405-eng-26 U.S. DOE, pp 1-26.

133. Benavides E.; Fajardo, M. "Closed Electropolishing System for Decontamination of Underwater Surfaces/Development of Vibratory Decontamination with Abrasive Media," In Pflugrad, K.; Bisci, R.; Huber, B.; Skupinski. E, Eds.; Decommissioning of Nuclear Installations; Elsevier Applied Science: London \& NY; pp 598-603.

134. Carson, D.R.; Shagula, B.P.; Moran, J.B. "Human Factors Assessments of Environmental Technologies," 95MC32260, U.S. DOE, Morgantown, WV, 1995; pp 1-11.

135. Mc Kernan M.L.; Schulmeister, A.R. "Surface Decontamination Utilizing Mechanical Vacuum Blasting Methods," SSDP-0035, U.S. DOE.

136. Pang, H.M.; Lipert, R.J.; Hamock, Y.M.; Bayrakal, S.; Gaul, K.; Davis, B.; Baldwin, D.P.; Edelson, M.C. "Laser Decontamination - A New Strategy for Facility Decommissioning."

137. Trends in Nuclear Decommissioning Costs., 1997; http://www.tlgservices.com.corprate/trends.htm. 


\section{APPENDIX C}

\section{TECHNOLOGY DATASET}


TABLE C1

Technology Dataset

\begin{tabular}{|c|c|c|c|c|c|c|c|c|c|c|c|c|}
\hline Technology Name & \begin{tabular}{|l} 
(Minimum) \\
Production \\
Rate, $\mathrm{ft}^{2} / \mathrm{hr}$ \\
\end{tabular} & $\begin{array}{l}\text { Maximum } \\
\text { Production } \\
\text { Rate, } \mathrm{ft}^{2} / \mathrm{hr} \\
\end{array}$ & $\begin{array}{c}\text { (Minimum) } \\
\text { Operating } \\
\text { Cost, } \$ / f^{2} \\
\end{array}$ & $\begin{array}{l}\text { Maximum } \\
\text { Operating } \\
\text { Cost, } \$ / \mathrm{ft}^{2} \\
\end{array}$ & $\begin{array}{l}\text { Cleaning } \\
\text { Depth, in. }\end{array}$ & \begin{tabular}{|l|} 
Number of \\
Passes to \\
Complete \\
Cleaning \\
\end{tabular} & $\begin{array}{c}(\text { Capital) } \\
\text { Cost Factor }\end{array}$ & $\begin{array}{c}\text { Size/ } \\
\text { Delivery } \\
\text { Factor }\end{array}$ & $\begin{array}{c}\text { Setup/ } \\
\text { Calibration } \\
\text { Factor } \\
\end{array}$ & $\begin{array}{c}\text { Number of } \\
\text { Workers }\end{array}$ & $\begin{array}{l}\text { Assumes } \\
\text { Labor is } \\
\text { Included } \\
\end{array}$ & Justification for Labor Inclusion/ Exclusion \\
\hline Mechanical Scabbling & 200 & 400 & 1.85 & 2.50 & 0.13 & 1 & 1 & 1 & 1 & 2 & $\mathrm{~N}$ & $\begin{array}{l}\text { Assumed that labor is not included because it is not included for MOOSE } \\
\text { and Squirrel listed at the same operating rate. }\end{array}$ \\
\hline Milling & 3 & & 0.75 & & 1 & 1 & 2 & 2 & 2 & 2 & $\mathrm{~N}$ & Labor estimated cost exceeds quoted operating cost. \\
\hline Drilling Spalling & 60 & 100 & 3.00 & 3.55 & 1 & 1 & 2 & 1 & 2 & 2 & $\mathrm{Y}$ & Educated guess \\
\hline Sand Blasting & 47 & & 5.00 & 10.00 & 0.06 & 1 & 1 & 1 & 1 & 2 & $\mathrm{~N}$ & Dickerson lists a separate operating cost and labor cost. \\
\hline Steel Grit & 11.6 & & 5.52 & & 0.01 & 1 & 1 & 1 & 1 & 2 & $\bar{Y}$ & Ebadian is the source for operating cost data. \\
\hline Plastic Blasting & 240 & & 0.20 & 2.15 & 0.06 & 2 & 1 & 1 & 1 & 2 & $\mathrm{~N}$ & Ebadian rate was much higher: $\$ 14$. \\
\hline Ultra-Pressure Water & 60 & & 2.00 & & 0.06 & 2 & 2 & 1 & 2 & 2 & $\bar{Y}$ & Rate is higher than Ebadian calculation. \\
\hline High-Pressure Water & 370 & & 0.06 & 2.00 & 0.06 & 2 & 2 & 1 & 2 & 2 & $\mathrm{~N}$ & Ebadian rate was much higher: $\$ 6$. \\
\hline Sponge Blasting & 32 & & 2.71 & & 0.06 & 1 & 2 & 2 & 1 & 3 & $\mathrm{Y}$ & Ebadian is the source for operating cost data. \\
\hline Soft Media Blasting - Metal & 120 & & 0.77 & & 0.003 & 1 & 1 & 2 & 1 & 2 & $\mathrm{Y}$ & Based on conversation with vendor \\
\hline Soft Media Blasting - Concrete & 60 & 100 & 10.00 & 12.00 & 0.13 & 1 & 1 & 2 & 1 & 2 & $\bar{Y}$ & $\begin{array}{l}\text { Quoted operating to labor estimated cost difference is already } \\
\text { considerably higher than for metal applications. }\end{array}$ \\
\hline Soda Blasting - Metal & 24 & & 4.17 & & 0.03 & 2 & 2 & 2 & 1 & 2 & $\mathrm{Y}$ & Ebadian is the source for operating cost data. \\
\hline Soda Blasting - Concrete & 60 & 240 & 5.00 & 7.00 & 0.03 & 2 & 2 & 2 & 1 & 2 & $\bar{Y}$ & $\begin{array}{l}\text { Quoted operating to labor estimated cost difference is already higher than } \\
\text { for metal applications. }\end{array}$ \\
\hline Shot Blasting & 30 & 3000 & 0.04 & 5.02 & 0.25 & 1 & 2 & 3 & 1 & 2 & $\bar{Y}$ & $\begin{array}{l}\text { The difference is cost between including and excluding labor is } \\
\text { inconsequential. }\end{array}$ \\
\hline Scarification MOOSE & 200 & 400 & 1.85 & 2.50 & 0.06 & 1 & 2 & 2 & 2 & 2 & $\mathrm{~N}$ & Based on conversation with vendor,operating cost does not include labor. \\
\hline $\begin{array}{l}\text { Squirrel Floor Scabbler \& } \\
\text { Corner Cutter } \\
\end{array}$ & 20 & 30 & 1.85 & 2.50 & 0.06 & 1 & 2 & 3 & 2 & 1 & $\mathrm{~N}$ & Based on conversation with vendor, operating cost does not include labor. \\
\hline Microwave & 40 & & 2.00 & & 2 & 1 & 2 & 2 & 3 & 2 & $\mathrm{~N}$ & Dickerson lists a separate operating cost and labor cost. \\
\hline $\mathrm{CO}_{2}$ Laser & 500 & 600 & 0.66 & 0.74 & 0.001 & 1 & 3 & 3 & 3 & 1 & $\overline{\mathrm{Y}}$ & $\begin{array}{l}\text { The difference in cost between including and excluding labor is } \\
\text { inconsequential. }\end{array}$ \\
\hline Ice Blasting - Metal & 5.2 & & 12.69 & & 0.06 & 2 & 2 & 2 & 2 & 2 & $\mathrm{Y}$ & Ebadian is the source for operating cost data. \\
\hline Ice Blasting - Concrete & 45 & & 1.00 & & 0.06 & 2 & 2 & 2 & 2 & 2 & $\mathrm{~N}$ & $\begin{array}{l}\text { Quoted operating to labor estimated cost difference is considerably lower } \\
\text { than for metal applications. }\end{array}$ \\
\hline Electrokinetic & 132 & & 0.42 & & 3 & 2 & 3 & 3 & 3 & 0 & & \\
\hline Electro-Hydraulic Scabbling & 20 & 40 & 0.65 & 1.85 & 0.6 & 1 & 3 & 2 & 3 & 2 & $\mathrm{~N}$ & Estimated labor cost exceeds quoted operating cost. \\
\hline $\begin{array}{l}\text { TechXtract or Corpex } \\
\text { Processes } \\
\end{array}$ & 16 & 100 & 4.00 & 25.00 & 2.0 & 1 & 1 & 1 & 1 & 2 & $\bar{Y}$ & $\begin{array}{l}\text { The difference in cost between including and excluding labor is } \\
\text { inconsequential. }\end{array}$ \\
\hline $\begin{array}{l}\text { Carbon Dioxide Blasting - } \\
\text { Metal }\end{array}$ & 12 & & 7.89 & & 0.04 & 1 & 2 & 2 & 3 & 2 & $\mathrm{Y}$ & Ebadian is the source for operating cost data. \\
\hline $\begin{array}{l}\text { Carbon Dioxide Blasting - } \\
\text { Concrete }\end{array}$ & 10 & 90 & 0.90 & 1.75 & 0.04 & 1 & 2 & 2 & 3 & 1 & $\mathrm{~N}$ & $\begin{array}{l}\text { Quoted operating to labor estimated cost difference is considerably lower } \\
\text { than for metal applications. }\end{array}$ \\
\hline
\end{tabular}

Continued... 
TABLE C1 (continued)

Technology Dataset

\begin{tabular}{|c|c|c|c|c|c|c|c|c|c|c|c|c|}
\hline Technology Name & $\begin{array}{c}\text { (Minimum) } \\
\text { Volume Rate of } \\
\text { Liquid } \\
\text { Secondary } \\
\text { Waste, } \mathrm{ft}^{3} / \mathrm{hr} \\
\end{array}$ & $\begin{array}{c}\text { Maximum } \\
\text { Volume Rate of } \\
\text { Liquid } \\
\text { Secondary } \\
\text { Waste, } \mathrm{ft}^{3} / \mathrm{hr} \\
\end{array}$ & $\begin{array}{l}\text { Density of Liquid } \\
\text { Secondary } \\
\text { Waste, } \mathrm{lb} / \mathrm{ft}^{3} \\
\end{array}$ & $\begin{array}{c}\text { (Minimum) } \\
\text { Volume Rate of } \\
\text { Solid Secondary } \\
\text { Waste, } \mathrm{ft}^{3} / \mathrm{hr}\end{array}$ & $\begin{array}{c}\text { Maximum } \\
\text { Volume Rate of } \\
\text { Solid Secondary } \\
\text { Waste, } \mathrm{ft}^{3} / \mathrm{hr} \\
\end{array}$ & \begin{tabular}{|c|} 
Density of Solid \\
Secondary \\
Waste, Ib/ft/ \\
\end{tabular} & Safety Factor & $\begin{array}{c}\text { Reliability } \\
\text { Factor }\end{array}$ & Description & Cleans Steel & Cleans Concrete & Process Type \\
\hline Mechanical Scabbling & 0 & & na & \begin{tabular}{|l|}
0 \\
\end{tabular} & & na & 6.57 & 8.21 & $\begin{array}{c}\text { Physical/mechanical, destructive } \\
\text { surface removal }\end{array}$ & NO & YES & Destructive \\
\hline Milling & 0 & & na & 0 & & na & 6.2 & 7.53 & $\begin{array}{c}\text { Physical/mechanical, destructive } \\
\text { surface removal }\end{array}$ & NO & 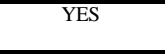 & Destructive \\
\hline Drilling Spalling & 0 & & na & 0 & & na & 6.13 & 7.8 & $\begin{array}{c}\begin{array}{c}\text { Physical/mechanical, destructive } \\
\text { surface removal }\end{array} \\
\end{array}$ & NO & $\overline{\mathrm{YES}}$ & Destructive \\
\hline Sand Blasting & 0 & & na & 1.41 & & 2.63 & 5.53 & 8 & $\begin{array}{l}\text { Physical/mechanical, } \\
\text { nondestructive }\end{array}$ & YES & YES & Nondestructive \\
\hline Steel Grit & 0 & & na & 0.02 & & 105 & 6.3 & 6.85 & $\begin{array}{l}\begin{array}{c}\text { Physical/mechanical, } \\
\text { nondestructive }\end{array} \\
\end{array}$ & 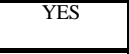 & 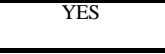 & Nondestructive \\
\hline Plastic Blasting & 0 & & na & 0.25 & & 55 & 6.23 & 5.88 & $\begin{array}{l}\text { Physical/mechanical, } \\
\text { nondestructive }\end{array}$ & 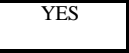 & 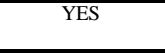 & Nondestructive \\
\hline \begin{tabular}{|l} 
Ultra-Pressure Water \\
\end{tabular} & 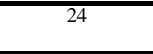 & 40 & 12.8 & 0 & & na & 6.23 & 7.55 & $\begin{array}{l}\text { Physical/mechanical, } \\
\text { nondestructive }\end{array}$ & $\begin{array}{c}\mathrm{YES} \\
\end{array}$ & $\begin{array}{c}\text { YES } \\
\end{array}$ & Nondestructive \\
\hline High-Pressure Water & 11 & & 12.8 & 0 & & na & 5.67 & 7.88 & $\begin{array}{l}\text { Physical/mechanical, } \\
\text { nondestructive }\end{array}$ & YES & YES & Nondestructive \\
\hline Sponge Blasting & 0 & & na & 688.2 & & 0.525 & 6.8 & 6.5 & $\begin{array}{l}\text { Physical/mechanical, } \\
\text { nondestructive }\end{array}$ & 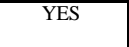 & 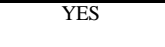 & Nondestructive \\
\hline Soft Media Blasting - Metal & 0 & & na & 0.06 & 0.2 & 52.9 & 6.8 & 5.09 & $\begin{array}{l}\text { Physical/mechanical, } \\
\text { nondestructive }\end{array}$ & $\begin{array}{c}\mathrm{YES} \\
\end{array}$ & NO & Nondestructive \\
\hline Soft Media Blasting - Concrete & 0 & & na & 0.06 & 0.2 & 52.9 & 6.8 & 5.09 & Physical/mechanical, destructive & NO & YES & Destructive \\
\hline Soda Blasting - Metal & $\overline{5.8}$ & & 13.8 & 0 & 0 & $\mathrm{na}$ & 5.77 & 6.85 & 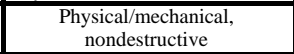 & $\overline{\mathrm{YES}}$ & NO & Nondestructive \\
\hline Soda Blasting - Concrete & 18 & 112 & 13.8 & 0 & 0 & na & 5.1 & 6.85 & $\begin{array}{c}\text { Physical/mechanical, } \\
\text { nondestructive }\end{array}$ & NO & $\overline{\mathrm{YES}}$ & Nondestructive \\
\hline Shot Blasting & 0 & & na & 0.09 & 87 & 294 & 6.33 & 7.94 & $\begin{array}{c}\text { Physical/mechanical, destructive } \\
\text { surface removal }\end{array}$ & 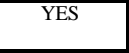 & 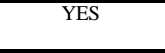 & Destructive \\
\hline Scarification MOOSE & 0 & & $\overline{\mathrm{na}}$ & 0 & & $\mathrm{na}$ & 6.6 & 8.21 & $\begin{array}{c}\text { Physical/mechanical, destructive } \\
\text { surface removal }\end{array}$ & NO & 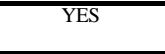 & Destructive \\
\hline $\begin{array}{l}\text { Squirrel Floor Scabbler \& } \\
\text { Corner Cutter }\end{array}$ & 0 & & $\mathrm{na}$ & 0 & & $\mathrm{na}$ & 6.6 & 7.58 & $\begin{array}{c}\begin{array}{c}\text { Physical/mechanical, destructive } \\
\text { surface removal }\end{array} \\
\end{array}$ & NO & $\overline{\mathrm{YES}}$ & Destructive \\
\hline Microwave & 0 & & na & 0 & & na & 7 & 5.26 & $\begin{array}{l}\text { Electrical/thermal/physical, } \\
\text { destructive surface removal }\end{array}$ & NO & $\begin{array}{c}\mathrm{YES} \\
\end{array}$ & Destructive \\
\hline $\mathrm{CO}_{2}$ Laser & 0 & & na & 0 & & $\mathrm{na}$ & 6.2 & 4.66 & Electrical/thermal, nondestructive & $\overline{\mathrm{YES}}$ & $\overline{\mathrm{YES}}$ & Nondestructive \\
\hline Ice Blasting - Metal & $\overline{3.2}$ & & 12.8 & 0 & & na & 6.3 & 6.84 & $\begin{array}{l}\text { Physical/mechanical, } \\
\text { nondestructive }\end{array}$ & $\overline{\mathrm{YES}}$ & NO & Nondestructive \\
\hline Ice Blasting - Concrete & 1.1 & 2.0 & 12.8 & 0 & & na & 6.3 & 6.84 & $\begin{array}{l}\text { Physical/mechanical, } \\
\text { nondestructive }\end{array}$ & NO & YES & Nondestructive \\
\hline Electrokinetic & nd & nd & & nd & & 0 & 6.3 & 4.13 & $\begin{array}{l}\text { Electrical/chemical/physical, } \\
\text { nondestructive }\end{array}$ & NO & 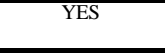 & Penetrating \\
\hline Electro-Hydraulic Scabbling & 2.0 & 4.0 & 12.8 & 0 & & na & 6.3 & 5.76 & $\begin{array}{c}\text { Physical/mechanical, destructive } \\
\text { surface removal }\end{array}$ & NO & 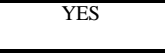 & Destructive \\
\hline $\begin{array}{l}\text { TechXtract or Corpex } \\
\text { Processes }\end{array}$ & 0.1 & 1.1 & 12.8 & 0 & & $\mathrm{na}$ & 6.3 & 5.63 & Chemical, nondestructive & $\begin{array}{c}\mathrm{YES} \\
\end{array}$ & $\begin{array}{c}\text { YES } \\
\end{array}$ & Nondestructive \\
\hline $\begin{array}{l}\text { Carbon Dioxide Blasting - } \\
\text { Metal }\end{array}$ & 0 & & $\mathrm{na}$ & 0 & & $\mathrm{na}$ & 6.1 & 5.96 & $\begin{array}{c}\text { Physical/mechanical, } \\
\text { nondestructive }\end{array}$ & $\begin{array}{c}\text { YES } \\
\end{array}$ & NO & Nondestructive \\
\hline $\begin{array}{l}\text { Carbon Dioxide Blasting - } \\
\text { Concrete }\end{array}$ & 0 & & na & 0 & & na & 6.1 & 5.96 & $\begin{array}{c}\text { Physical/mechanical, } \\
\text { nondestructive }\end{array}$ & NO & YES & Nondestructive \\
\hline
\end{tabular}

na $=$ Not available

Continued ... 
TABLE C1 (continued)

Technology Dataset

\begin{tabular}{|c|c|c|c|c|c|c|c|c|}
\hline Technology Name & Stage of Technology & $\begin{array}{c}\text { Waste } \\
\text { Type }\end{array}$ & Cleans Floors & $\begin{array}{l}\text { Cleans } \\
\text { Walls }\end{array}$ & $\begin{array}{l}\text { Cleans } \\
\text { Ceilings }\end{array}$ & \begin{tabular}{|c|} 
Handles Hard \\
to Reach Areas
\end{tabular} & $\begin{array}{l}\text { On-Line } \\
\text { Analysis }\end{array}$ & $\begin{array}{c}\text { Extra Utilities } \\
\text { Required }\end{array}$ \\
\hline Mechanical Scabbling & Commercial scale & Solid & YES & NO & YES & NO & NO & NO \\
\hline Milling & Conceptual for decontamination & Solid & YES & NO & NO & NO & NO & NO \\
\hline Drilling Spalling & Commercial scale & Solid & YES & YES & YES & NO & NO & NO \\
\hline Sand Blasting & Commercial scale & Solid & YES & YES & YES & YES & NO & NO \\
\hline Steel Grit & Commercial scale & Solid & YES & YES & YES & YES & NO & NO \\
\hline Plastic Blasting & Commercial scale & Solid & YES & YES & YES & YES & NO & NO \\
\hline Ultra-Pressure Water & Commercial scale & Liquid & YES & YES & YES & YES & NO & YES \\
\hline High-Pressure Water & Commercial scale & Liquid & YES & YES & YES & YES & NO & NO \\
\hline Sponge Blasting & Commercial scale & Solid & YES & YES & YES & YES & NO & NO \\
\hline $\begin{array}{l}\text { Soft Media Blasting - } \\
\text { Metal }\end{array}$ & Commercial scale & Solid & YES & YES & YES & YES & NO & NO \\
\hline $\begin{array}{l}\text { Soft Media Blasting - } \\
\text { Concrete }\end{array}$ & Commercial scale & Solid & YES & YES & YES & YES & NO & NO \\
\hline Soda Blasting - Metal & Commercial scale & Liquid & YES & YES & YES & YES & NO & NO \\
\hline Soda Blasting - Concrete & Commercial scale & Liquid & YES & YES & YES & YES & NO & NO \\
\hline Shot Blasting & Commercial scale & Solid & YES & YES & YES & NO & NO & NO \\
\hline Scarification MOOSE & Commercial scale & Solid & YES & NO & NO & NO & NO & NO \\
\hline $\begin{array}{l}\text { Squirrel Floor Scabbler \& } \\
\text { Corner Cutter }\end{array}$ & Commercial scale & Solid & YES & YES & YES & YES & NO & NO \\
\hline Microwave & Full-scale prototype & Solid & YES & YES & YES & YES & NO & YES \\
\hline $\mathrm{CO}_{2}$ Laser & Demonstration & Solid & YES & YES & YES & YES & YES & YES \\
\hline Ice Blasting - Metal & Commercial scale & Liquid & YES & YES & YES & YES & NO & NO \\
\hline Ice Blasting - Concrete & Commercial scale & Liquid & YES & YES & YES & YES & NO & NO \\
\hline Electrokinetic & Bench Scale & Liquid & YES & NO & NO & YES & NO & NO \\
\hline $\begin{array}{l}\text { Electro-Hydraulic } \\
\text { Scabbling }\end{array}$ & Developmental & Liquid & YES & NO & NO & NO & NO & NO \\
\hline $\begin{array}{l}\text { TechXtract or Corpex } \\
\text { Processes }\end{array}$ & Commercial scale & Liquid & YES & YES & YES & YES & NO & NO \\
\hline $\begin{array}{l}\text { Carbon Dioxide Blasting - } \\
\text { Metal }\end{array}$ & Commercial scale & Solid & YES & YES & YES & YES & NO & YES \\
\hline $\begin{array}{l}\text { Carbon Dioxide Blasting - } \\
\text { Concrete }\end{array}$ & Commercial scale & Solid & YES & YES & YES & YES & NO & YES \\
\hline
\end{tabular}


TABLE C2

Dataset References

\begin{tabular}{|c|c|c|}
\hline \multirow{2}{*}{ Technology Name } & & \\
\hline & Source & Footnotes \\
\hline Mechanical Scabbling & Dickerson Tы 3.4 \& Vanderbilt pg. 34 & (a.), (b.), (c.) \\
\hline Milling & Dickerson Tbl 3.5, 3.6 \& Vanderbilt pg.34 & (a.) \\
\hline Drilling Spalling & Halter (1) pp. $16,22,26,28$ & \\
\hline Sand Blasting & Dickerson Tbl 3.5, 3.6; Vanderbilt Tbl 5-1 & (a.), (c.) \\
\hline Steel Grit & Ebadian Tbl 2; conversation with vendor & (a.) \\
\hline Plastic Blasting & Dickerson Tbl 3.5; Ebadian Tbl 2 & (c.), (d.), (e.) \\
\hline Ultra-Pressure Water & Dickerson Tbl 3.5, 3.6; Ebadian Tbl 2 & (c.), (e.), (f.), (g.) \\
\hline High-Pressure Water & Dickerson Tbl 3.5, 3.6, 4.3; Ebadian Table 2 & (c.), (e.), (f.), (g.) \\
\hline Sponge Blasting & Dickerson Tbl 3.4; Ebadian Table 2; written correspondence with vendor & (d.), (e.) \\
\hline Soft Media Blasting - Metal & written correspondence with vendor & \\
\hline Soft Media Blasting - Concrete & Dickerson Tb 3.5, 3.6, App C; SAIC Tbl 3-3; written correspondence with vendor & \\
\hline Soda Blasting - Metal & Ebadian Tbl 2 \& 3; conversation with vendor & (h.) \\
\hline Soda Blasting - Concrete & Dickerson Tbl 3.5, 3.6, App C; conversation with vendor & (h.) \\
\hline Shot Blasting & Dickerson p. 3-16, Tb 3.5, 3.6; SAIC Tabl 3-3; conversation with vendor & \\
\hline Scarification MOOSE & Dickerson App C; conversation with vendor & \\
\hline $\begin{array}{l}\text { Squirrel Floor Scabbler \& } \\
\text { Corner Cutter }\end{array}$ & Dickerson Tb1 3.5, App C; conversation with vendor & \\
\hline Microwave & Dickerson Tbl 3.5, 3.6 & \\
\hline $\mathrm{CO}_{2}$ Laser & F2 Associates & \\
\hline Ice Blasting - Metal & Ebadian Tbl 2 & (e.), (f.), (g.) \\
\hline Ice Blasting - Concrete & Dickerson Tbl 3.6, App C & (e.), (f.), (g.), (i.) \\
\hline Electrokinetic & Vanderbilt Tb1 5-1; Dickerson Tbl 3.5, App C & \\
\hline Electro-Hydraulic Scabbling & Dickerson Tb 3.5, 3.6; SAIC Table 3-3 & (f.), (j.), (k.) \\
\hline $\begin{array}{l}\text { TechXtract or Corpex } \\
\text { Processes }\end{array}$ & Dickerson Tbl 2.7, App C; Bonem & (f.), (j.) \\
\hline $\begin{array}{l}\text { Carbon Dioxide Blasting - } \\
\text { Metal }\end{array}$ & Ebadian Tbl 2, 3; conversation with vendor & (1.) \\
\hline $\begin{array}{l}\text { Carbon Dioxide Blasting - } \\
\text { Concrete }\end{array}$ & Dickerson Tbl 3.5, App C; conversation with vendor & (1.) \\
\hline
\end{tabular}

Notes: $\quad 1$. It is assumed that destructive technologies will not work for metal substrates.

2. Secondary waste includes only media used during processes, not water spray, HEPA filters, or anything else used for dust control and collection.

Footnote Key

(a.) Default value: one pass to clean was assumed for destructive technologies and sandblasting.

(b.) Default value for number of workers is two.

(c.) Assumed that the technology handles floors, walls, and ceilings because it handles hard to reach areas.

(d.) Density of secondary waste was calculated based on data from Ebadian.

(e.) Default value: 0.06 inches was assumed for cleaning depth.

(f.) Default value: the density of water was used for secondary waste density.

(g.) Default value: two passes to clean were assumed for nondestructive technologies for which references were not located.

(h.) Experimental density of a saturated $\mathrm{NaHCO}_{3}$ solution

(i.) Default value: production rate was listed as "similar to other blasting technologies (Dickerson). Assumed $45 \mathrm{ft}^{2} / \mathrm{hr}$.

(j.) Default value: two workers is assumed.

(k.) Depth of cleaning was listed as "up to 1 inch" (Dickerson Table 3.5).

(I.) Secondary waste data in Ebadian Table 2 contradict the text in Table 1 which states, " $\mathrm{CO}_{2}$ media vaporize, leaving only the volume of dry coating residue waste."

TABLE C3 


\section{Source Index}

\begin{tabular}{|c|c|}
\hline Bonem & $\begin{array}{l}\text { Bonem, Michael W. "Economical Decontamination of Concrete and Metal Using the TechXtract }{ }^{\mathrm{TM}} \text { Process," Proceedings of the International } \\
\text { Topical Meeting on Nuclear and Hazardous Waste Management Spectruc '94, 1994,pp. 2434-2438. [2027] }\end{array}$ \\
\hline Dickerson & $\begin{array}{l}\text { Dickerson, K.S.; Wilson-Nichols, M.J.; Morris, M.I. "Contaminated Concrete: Occurance and Emerging Technologies for DOE Decontamination," } \\
\text { DOE/ORO/2034; U.S. Department of Energy Oak Ridge National Laboratory, 1995; pp 1-352. } \\
\text { Tb1 2.7 = Past experience in concrete decontamination } \\
\text { Tbl 3.5 = Summary of candidate technologies for concrete decontamination } \\
\text { Tbl } 3.6 \text { = Estimated costs for emerging concrete decontamination technologies } \\
\text { Tbl 4.3 = Results from technology demonstration evaluation } \\
\text { App C = Technology Description Fact Sheets } \\
\text { (a) comparable TechXtract(TM) process }\end{array}$ \\
\hline Ebadian & $\begin{array}{l}\text { Ebadian, M.A.; Lagos, L.E.; Boudreaux, J.F.; Clark, T.R.; Miller, L.K. "Analysis of Potential Surface Blasting Decontamination Technologies for } \\
\text { Structural Steel," Fernald Environmental Restoration Management Corporation: Cincinatti, OH, 1995; pp 1-41. [2023] } \\
\text { Tbl } 2 \text { = Operational Parameters -<((numbers listed are for painted steel plates }))>- \\
\text { Tbl } 3 \text { = Utility/Nedia Requirements }\end{array}$ \\
\hline Grieco & $\begin{array}{l}\text { Grieco, S.A.; Neubauer, E.D.; Rheea, J.R. "Removal and Treatment of Radioactive, Organochlorine, and Heavy Metal Contaminants from Solid } \\
\text { Surfaces," In Radioactive and Hazardous Surface Decontamination Utilizing Soda Blasting; O'Brien and Gere Technical Services, Inc.: East } \\
\text { Syracuse, NY, 1995; pp 1-10. [2050] }\end{array}$ \\
\hline Halter & $\begin{array}{l}\text { Halter, J.M.; Sullivan, R.G.; Bevan, J.L. "Surface Concrete Decontamination Equipment Developed by Pacific Northwest Laboratory," Prepared } \\
\text { for the U.S. Department of Energy under Contract DE-AC06-76RLO } 1830 \text { 1982. pp26-29. }\end{array}$ \\
\hline SAIC & $\begin{array}{l}\text { SAIC. Market Assessment Decontamination of Radioactivity - Contaminated Concrete; 1996. [2478]Tbl 3-3 = Representative Listing of } \\
\text { Companies in the Concrete Decontamination Market and Their Associated Techs. (all except Shot Blasting } \$ / \mathrm{ft}^{2} \text { accepted from Dickerson) }\end{array}$ \\
\hline Vanderbilt & $\begin{array}{l}\text { Ayers, K.W.; Boren, J.K.; Stephen, A.; Parker, F.L. "Reuse of Concrete from Contaminated Structures. Part 1: Economic Analysis of the Feasibility } \\
\text { of Recycling Contaminated Concrete," DE-FG05-94OR22343; Department of Civil and Environmental Engineering, Vanderbilt University: } \\
\text { Nashville, TN, 1996. [[primary source is Dickerson]] } \\
\text { Tbl 5-1 = Technology Summary Table }\end{array}$ \\
\hline
\end{tabular}


APPENDIX D

\section{SURFACE DECONTAMINATION ASSISTANT MODEL}




\section{SURFACE DECONTAMINATION ASSISTANT MODEL DESIGN}

\section{SURFACE CHARACTERISTICS AND WASTE DEFINITION}

The model determines a performance index (PI) for decontamination of a metal or concrete surface using a user-defined scenario as input. The user-defined scenario can include various types of substrate material, amount of area to be removed/decontaminated, depth of removal, surface orientation (e.g., floor), type of contamination, type of transportation used for disposal, distance to disposal site, and fees charged for disposal. Outputs include the performance indices listed below, which together provide an overall PI for a decontamination technology:

- Surface removal

- Transportation

- Disposal

- Environment, health, and safety

- Implementability, operation, and maintenance

\section{Assumptions}

- User knows types of contamination that occurred on site.

- User has knowledge of surfaces to be decontaminated.

- Depth of contamination is defined.

\section{TECHNOLOGY SELECTION}

Included within the model is a dataset of technologies that contains information on the operational aspects of each technology listed. The user can view this information while using the model to help determine which process is most applicable for the user's situation. Listed below are the fields within the dataset records that are based on the variables used in determining the overall PI for a technology:

- Destructive or nondestructive process

- Substrate-cleaning ability - metal or concrete or both

- Surface-cleaning ability only

- Production rate

- Operating cost

- Volume, phase, and density of secondary waste

- Depth of cleaning

- Number of passes needed to achieve $100 \%$ decontamination

- Ability to clean vertical and overhead surfaces

- Ability to clean hard-to-reach areas (corners, cracks, etc.)

- On-line analysis capabilities

- Usual utility costs 
- Environment, health, and safety factors

- Implementability, operation, and maintenance

- Stage of technology development

- Number of workers necessary to operate technology

- Capital cost, delivery and setup factors

- Labor costs

Decontamination technologies are classified as either destructive or nondestructive processes. Destructive process are considered to have $100 \%$ effectiveness of decontamination due to the actual removal of the surface containing the contamination. For nondestructive processes, the model assumes that each technology has the ability to achieve complete removal of the contaminants even if the surface must be cleaned several times. Technologies that are not applicable to cleaning a particular substrate (concrete, metal) will not be selectable by the user for that particular application. For example, if the contaminant has seeped into a concrete floor, a surface-cleaning technology (nondestructive) will no longer be a viable selection. The model also asks the user the orientation of the contaminated surface, then excludes any technology from selection that is not able to clean surfaces of that orientation.

\section{Assumptions}

- All technologies are capable of $100 \%$ decontamination of the surface.

- Operation cost is a service cost. The inclusion of labor cost in the operating cost is determined on each technology in the dataset.

\section{CALCULATION OF SURFACE REMOVAL FACTOR}

This section describes how the cost factor of surface decontamination is determined. Variables used in the calculation include operating cost, production rate, depth of removal, number of passes necessary for $100 \%$ cleaning, area to be decontaminated/removed, labor and setup costs.

The model can determine several different contamination scenarios: 1) contamination that has seeped into the concrete below the surface coating, 2) decontamination of a room or building, and 3) easy- versus hard-to-reach areas to be decontaminated.

In Scenario 1, the contamination has seeped down into the concrete. There are two possible ways to achieve the objective of decontamination: 1) removal of both the surface coating and the contaminated concrete with one technology (this technology would have to be a destructive process or a process that is capable of penetrating the contaminated concrete) and 2) performing two separate runs of the model using a nondestructive process to remove the surface coating and another to decontaminate the concrete. One reason for using two different technologies is to reduce secondary waste by using a nondestructive low-waste-producing technology to remove the surface coating. 
Scenario 2 involves decontamination of rooms or buildings, which would include horizontal and vertical surfaces. Some technologies are not capable of cleaning vertical surfaces or ceilings. There are two possible ways to approach this scenario: 1) enter the total surface area for the building/room and use one technology that is capable of cleaning all of the surfaces or 2) use several technologies to decontaminate the building/room, and run the model a separate time for each technology and different surface orientation.

Scenario 3 involves areas that are hard to reach, defined as a deep crack or crease or an area within 6 inches of the corners of a room, versus areas that are easily cleaned. Several technologies are not capable of cleaning within 6 inches of a corner. 1) Select a technology that is capable of cleaning all of the contaminated surface. 2) Run the model twice, once using a technology to clean the easily accessible areas, but unable to reach into the corners, and a second time using a technology that is capable of cleaning in the corners.

\section{Assumption}

- User is willing to use one or more different technologies to decontaminate a site.

\section{Algorithm Description}

For the first step, the model determines the total number of passes needed to completely remove the contaminants using an equation based upon the depth of removal, the depth to which the technology can clean per pass, and the cleaning effectiveness of the technology (Ref. 22, Appendix B, pp 1-26).

The time needed to complete the user-defined decontamination task is provided in a second calculation. The parameters taken into consideration are the surface area to be cleaned, the production rate of a technology, the number of passes necessary, and the percent of the area that is hard to reach (as defined above). A compensation factor is included that determines the rate at which the total hours to decontaminate will increase because of areas that are more timeconsuming to clean (hard-to-reach areas). The total hours will be used later to determine the amount of secondary waste produced by a technology.

A third equation determines the surface removal costs for a technology by multiplying total time calculated above by the technology operating cost and production rate, incorporating labor costs, if necessary. Floor surface is treated apart from vertical and ceiling surface areas because some technologies are able to decontaminate only floors (Ref. 22, Appendix B, pp 1-26).

\section{CALCULATION OF WASTE VOLUMES AND WEIGHT}

Two primary waste streams are produced during the decontamination process. One is surface debris, resulting from the actual removal of the contaminated surface, and the other is the secondary waste produced from the technology during the cleaning process. The secondary waste can be in liquid or solid phase, and is indicated in the technology dataset. For future definition 
of the types of waste to be disposed of at a storage or disposal site, the model tracks both weight and volume of the primary solid waste and secondary liquid and solid waste. Each phase of waste will be treated differently during transportation and disposal.

\section{Assumptions}

- No transuranic waste or spent nuclear fuel is being transported or disposed of.

- Technologies and site personnel are capable of removing one specific area, then another, without mixing the removed waste.

- Solid and liquid waste streams are kept separate.

- Primary substrate waste is always solid.

- On-site disposal will use existing trucks and personnel.

- Remote-handling waste cannot be shipped by rail.

\section{Algorithm Description}

The volume and weight of debris resulting from the removal of the contaminated surface are calculated by multiplying the surface area by the depth of removal and the solid surface volume by surface density, respectively.

Each technology produces a different amount and phase of secondary waste from the decontamination process (Ref. 1, Appendix B, pp 1-26). The total volume and weight of the secondary waste for both solid and liquid phase are determined by multiplying the volume and weight of waste produced by each technology per hour by the total number of hours.

The total volume amount of solid waste produced during the decontamination process is determined by adding the volume of surface debris and the volume of secondary waste. The amount of solid secondary waste is determined using the percentage of secondary waste that is solid from the technology dataset.

\section{Waste Classification}

Most U.S. Department of Energy (DOE) waste streams from decontamination processes fit one of the following categories: low-level waste (LLW), greater-than-Class C (GTCC) LLW and DOE equivalent waste, transuranic waste (TRU), spent nuclear fuel (SNF), and hazardous waste. (Ref. 26, Appendix B, p 1). These wastes streams are grouped together into three transportation categories:

- Contact-handled (<200 mrem/hr contact dose)

- Remote-handled (>200 mrem/hr contact dose) 
- Hazardous waste

Most storage/disposal facilities accept LLW, MLLW, and TRU wastes (Refs. 26, 102, 137, Appendix B). For ease of use, the model classifies waste as contact-handled (CH) $(<200 \mathrm{mrem} / \mathrm{hr}$ contact dose) or remote-handled (RH) (>200 mrem/hr contact dose) for transportation and disposal. Solid $\mathrm{CH}$ waste can be disposed of on-site, thus lowering disposal costs. All liquid $\mathrm{CH}$ waste is assumed to be disposed of at a DOE or commercial disposal facility.

Another type of waste produced during the decontamination process is general construction and demolition (C\&D) waste. Uncontaminated concrete can be disposed of in a C\&D landfill at a default charge of $\$ 7 / \mathrm{yd}^{3}$ (Ref. 3, Appendix B).

\section{CALCULATION OF TRANSPORTATION COSTS}

Waste is classified for shipping as either contact- or remote-handled. Waste also can be transported by either truck or rail with specific weight restrictions and container device restrictions. As noted in a DOE technology assessment, "The volume of remote-handled waste is very small and does not warrant an estimate of rail costs in addition to truck costs" (Ref. 2, Appendix B, p 9). Also, the standard remote-handled containers are not designed for rail shipment. For this reason, the model does not consider rail shipment of remote-handled waste.

Transportation costs are determined in the form of cost-per-loaded-mile (CPLM) format. Most transportation is by truck, but rail can be used where practical. The CPLM unit rate is a variable cost dependent on the distance traveled. It has two subcomponents:

- Carrier cost - covers the variable costs associated with the cargo carrier. The carrier is the entity that takes title to the waste from the shipper during transportation, i.e., the trucking or railroad company.

- Hardware costs - the variable costs associated with procuring and maintaining the special hardware used during the transportation of waste. Special hardware consists mainly of trailers and railroad cars equipped with special tight-sealing enclosures or shielded casks.

Fixed costs generally consist of demurrage cost of the carrier and the hardware used in the shipment, which are independent of the distance traveled. Fixed costs are incurred during loading and unloading operations.

Guidelines for liquid waste shipments by truck or rail differ from those for solid shipments because of the need to provide secondary containment of spills that might occur in transit. Liquid components will only be $50 \%$ of the shipment volume. A common method used for packaging liquids is to place the liquid waste in a 30-gal closed-top drum, which is then placed in a 55-gal open-head drum. Absorbent is placed between the two containers, allowing the absorbent to remain noncontaminated, not adding to the disposal costs (Ref. 26, Appendix B). 


\section{Assumptions}

- On-site disposal will be solid waste only.

- All loads are full shipments.

\section{Algorithm Description}

\section{Truck - Contact-Handled Waste}

- 48-ft-long unshielded truck trailers

- Solid type of waste: LLW, MLLW, alpha LLW, alpha MLLW

- Solid load: 44,000 lb per shipment - 88 drums @ 500 lb

- Liquid type of waste: LLW, MLLW

- Liquid load: Type A container, 44,000 lb per shipment - 88 drums @ $500 \mathrm{lb}$

A calculation is done to determine the number of truckloads necessary to transport the waste to a DOE storage/disposal facility. 2600 gallons is the estimated amount of liquid per shipment. Multiplying 2600 gallons by the density of water equals 21,688 lb/shipment (Ref. 26, Appendix B). Another computation determines the cost of transportation by multiplying the number of loads by the one-way distance traveled to a disposal facility and charge per mile. For the cost per mile, all distances traveled to DOE storage/facility sites are considered to be over 300 miles.

The fixed costs are multiplied by the number of loads and added to the total cost. The format is the same: 1) determine the number of loads necessary to remove waste and 2) calculate the transportation cost for rail $\mathrm{CH}$, truck $\mathrm{RH}, \mathrm{CH}$ on-site disposal, and $\mathrm{C} \& \mathrm{D}$ disposal costs.

\section{Rail - Contact-Handled Waste}

- 40-ft-long intermodel (sea-land) containers

- Solid type of waste: LLW, MLLW

- Liquid load: Type B container, 38,000 lb per container - 76 drums @ $500 \mathrm{lb}$

- Load: 44,000 lb per container - 11 boxes@ 3945 lb or 38,000 lb per container-76 drums@500 lb

- Liquids - number of shipments = total quantity of liquid gal/18,240 lb

\section{Truck - Remote-Handled Waste}

- Type of Waste: LLW, MLLW, alpha LLW, alpha MLLW, GTCC/DOE equivalent waste

- Load: 13,400 lb per shipment - 14-55 gallon drums per shipment

- Liquids - number of shipments = total quantity of liquid gal/6422 lb 


\section{Truck - On-Site Disposal}

- Mass of solid waste

- Number of truckloads at 44,000 lb per truckload

- Fixed costs for loading/unloading and other costs associated with the use of trucks (fuel, etc.)

\section{DETERMINATION OF DISPOSAL FEES}

The fees charged by DOE and commercial storage/disposal facilities vary greatly from location to location (Refs. 3, 102, 137, Appendix B). The model uses an average for the different types of waste, which is considered fair, because the fee is the same for each technology. If the user wishes to change or knows the fee charged by a particular facility, that number can be entered instead:

- Contact-handled waste, off-site - High $\$ 300 / \mathrm{ft}^{3}$ (Ref. 137, Appendix B), medium $\$ 150 / \mathrm{ft}^{3}$ (Ref. 102, Appendix B, ), low $\$ 100 / \mathrm{ft}^{3}$ (Ref. 57, Appendix B)

- Contact-handled waste, on-site $-\$ 60 / \mathrm{ft}^{3}$ (Ref. 26, Appendix B)

- Remote-handled waste - High $\$ 740 / \mathrm{ft}^{3}$, medium $\$ 300 / \mathrm{ft}^{3}$, low $\$ 150 / \mathrm{ft}^{3}$ (Ref. 102, Appendix B )

- Construction and demolition waste $-\$ 0.26 / \mathrm{ft}^{3}$ (Ref. 3, Appendix B)

\section{Assumptions}

- User can use default values or will enter local disposal.

\section{Algorithm Description}

The disposal values are determined by multiplying the volume of material to be disposed by the appropriate fee.

\section{CALCULATION OF TECHNOLOGY PERFORMANCE INDICES}

A PI is computed for each technology when it is selected. PIs can be compared against those for another technology if the decontamination scenario input values are identical. The higher the PI for a technology, the better the technology did decontaminating that scenario. The overall PI is composed of five different factors: surface removal, transport, disposal, safety, and maintenance. To determine the safety and maintenance factors, performance scores were given each of the cleanup technologies in the areas of operation, maintenance, implementability, and environment, health, and safety (Ref. 57, Appendix B). The technologies were assigned nominal 
performance scores on a scale of 1 to 10 , with 10 being the best. The criteria used were as follows:

- Implementability

- Availability of the technology

- Previous use of the technology

- State of development of environmental management (EM) applications

- Flexibility and adaptability

- Operation and maintenance

- Setup

- Cleaning operations

- Equipment cleanup after shutdown

- Equipment maintenance

- Environment, health, and safety

- Regulatory compliance

- Emissions of toxic gases, vapors, and dust

- Worker exposure

The performance scores were independently assigned to the criteria by three raters: a senior chemical engineer with process experience, a research engineer, and a senior research chemist with recent background in developing a computer model for evaluating alternative surfacecleaning methods (Ref. 57, Appendix B).

\section{Algorithm Description}

The costs for surface removal, transportation and waste disposal for each technology are the basis for those performance indices. The surface removal costs come from the previously described surface removal factor. The transportation and waste disposal costs are calculated by summing the costs of all potential components. For example, all of the different types of waste disposal costs are added together ( $\mathrm{CH}$ on-site, $\mathrm{CH}$ off-site, $\mathrm{RH}$ on-site, $\mathrm{RH}$ off-site, $\mathrm{C} \& \mathrm{D}$ waste).

Since the surface removal, transportation and waste disposal factors are all costs, the smaller the resultant factor, i.e., a lower cost, is desirable. To obtain a PI number that gets larger to indicate a greater value, each factor is divided into the minimum factor for all technologies compared.

The software allows the user the ability to give one PI more weight, or importance, than another PI in the calculation of an overall PI by giving each component a priority ranking. Each PI is assigned a priority rank with a value of 1-10, with 10 being the best. The program takes each PI and multiplies its value by the priority ranking given by the user, then sums together the five PIs and divides by the maximum sum of all technologies compared. 
APPENDIX E

\section{MODEL DESIGN EQUATIONS}




\section{Variables:}

$\mathrm{NP}$ is the number of passes [unitless].

$\mathrm{RD}$ refers to removal depth [length].

$\mathrm{RC}$ is the surface removal cost [dollars].

$\mathrm{PI}$ is for technology performance indices [index specific units].

$\mathrm{C}$ is for cost [dollars/ $\mathrm{ft}^{2}$ for operating costs; dollars/hr for labor costs].

$\mathrm{NW}$ is the number of workers required to operate a technology [unitless].

A refers to an area [length $\left.{ }^{2}\right]$.

Cap refers to (capital) cost factor.

Siz refers to size/delivery factor.

$\mathrm{Cal}$ refers to setup/calibration factor.

Setup refers to the setup cost.

$\mathrm{V}$ refers to a volume [length ${ }^{3}$.

$M$ refers to a mass [mass].

$\mathrm{D}$ refers to density [mass/length ${ }^{3}$.

Time refers to a length of time [time].

$\mathrm{PR}$ is the production rate [length ${ }^{2} / \mathrm{time}^{\mathrm{im}}$.

$\stackrel{1}{1} \quad$ HR is the portion of the surface which is hard to reach [length ${ }^{2}$.

$\mathrm{V} 2 \mathrm{~W}$ is the rate (or amount) of secondary waste volume [length ${ }^{3} / \mathrm{time}$ ([length $\left.\left.{ }^{3}\right]\right)$.

$\mathrm{M} 2 \mathrm{~W}$ is the rate (or amount) of secondary waste mass [mass/time] ([mass]).

$\mathrm{S}$ combined with V or M (e.g., VS) is a volume or mass of solid.

$\mathrm{L}$ combined with $\mathrm{V}$ or $\mathrm{M}$ (e.g., VL) is a volume or mass of liquid.

$\%$ Solid is the percentage of the external media used by the technology which is solid.

$\mathrm{CT}$ is the cost for trucking.

$\mathrm{CR}$ is the cost for rail transport.

On combined with CT or CR is for on-site transportation.

Off combined with CT or CR is for off-site transportation.

$\mathrm{f}$ combined with $\mathrm{S}$ or $\mathrm{L}$ is a disposal cost factor.

\section{Subscripts:}

Tech subscript refers to technology-specific variables.

Coat refers to the substrate coating.

Sub refers to the substrate.

Surf refers to surface.

Labor refers to workers that operate technology. 
Tot refers to totals for the entire surface removal operation.

Fact refers to generic factors (e.g., factor to compensate for hard-to-reach areas).

$\mathrm{CH}$ refers to contact-handled waste.

$\mathrm{RH}$ is remote-handled waste.

$\mathrm{CD}$ is construction and demolition waste.

$\mathrm{Rec}$ is for recyclable materials.

Initial removal depth

$\mathrm{RD}_{\text {Init }}\left(\mathrm{RD}_{\text {Coat }}, \mathrm{RD}_{\text {Sub }}\right):=\mathrm{RD}$ Coat $+\mathrm{RD}_{\text {Sub }}$

Total number of passes to remove surface

NOTE: If $\mathrm{NP}_{\mathrm{T}}$ is not an integer, round up to the next integer.

$N P_{\text {Tot }}\left(N_{\text {Tech }}, R_{\text {Tech }}, R_{\text {Init }}\right):=N P_{\text {Tech }} \cdot \frac{R_{\text {Init }}}{R D_{\text {Tech }}}$

After determining NP ${ }_{\text {it }}$, we must now recalculate the total removal depth to compensate for additional depth to make a full pass. When destructive technologies are used to remove surface coatings, we must include a removal depth of substrate into the equation. Therefore, we introduce Destructive factor Des.

If technology is non-destructive, Des=1. If technology is destructive, Des=0.

Total removal depth

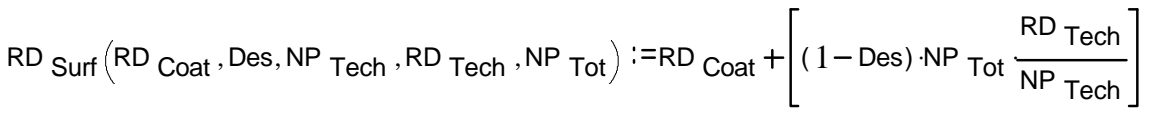

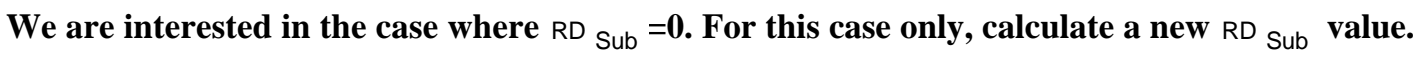

Removal depth of substrate

$\mathrm{RD}$ Sub $\left(\mathrm{RD}_{\text {Coat }}, \mathrm{RD}\right.$ Surf $):=\mathrm{RD}$ Surf $-\mathrm{RD}$ Coat

Total number of hours to remove surface

Time Tot $\left(A_{\text {Surf }}, \mathrm{HR}_{\text {Surf }}, \mathrm{PR}_{\text {Tech }}, \mathrm{NP} \mathrm{Tot}_{\text {Tot }}, \mathrm{HR}\right.$ Fact $):=\left[\left(\mathrm{HR}_{\text {Fact }}-1\right) \cdot \mathrm{HR}_{\text {Surf }}+\mathrm{A}_{\text {Surf }}\right] \cdot \frac{\mathrm{NP} \text { Tot }}{\mathrm{PR} \text { Tech }}$

The setup factor is a constant the purpose of which is to give weight to the tech setup cost with respect to the operating cost. The preliminary value for this factor is $\mathbf{2 0 0 0}$. 
Determination of Technology Setup Cost

$\mathrm{Setup}_{\text {Tech }}\left(\mathrm{Cap}_{\text {Tech }}, \mathrm{Siz}_{\text {Tech }}, \mathrm{Cal}_{\text {Tech }}\right)=\mathrm{Cap}_{\text {Tech }}+\mathrm{Siz}_{\text {Tech }}+\mathrm{Cal}_{\text {Tech }}$

We need to incorporate labor costs into the operating costs. If labor is included in the operating cost listed in the dataset, labor=0, else labor=1. We also want to incorporate the setup factor into the cost equation.

This value may change: $C_{\text {Labor }}:=21.875$

Surface removal cost (units are dollars)

$R C_{\text {Surf }}\left(\right.$ Time Tot, $\mathrm{C}_{\text {Tech }}$, labor, NW Tech, $\mathrm{C}_{\text {Labor }}, \mathrm{PR}$ Tech, Setup Tech, Setup Fact $):=\left(\mathrm{C}_{\text {Tech }} \cdot \mathrm{PR}\right.$ Tech + labor $\cdot \mathrm{NW}$ Tech $\left.\cdot \mathrm{C}_{\text {Labor }}\right) \cdot$ Time $_{\text {Tot }}+\left(\right.$ Setup $_{\text {Tech }} \cdot$ Setup Fact $)$

Volume of surface to remove

$v_{\text {Surf }}\left(\mathrm{A}_{\text {Surf }}, \mathrm{RD}\right.$ Surf $):=\mathrm{A}$ Surf ${ }^{\mathrm{RD}}$ Surf

Mass of surface to remove

$M_{\text {Surf }}\left(A_{\text {Sur }}, R D_{\text {coat }}, D_{\text {coat }}, R D_{\text {Sub }}, D_{\text {Sub }}\right)=A_{\text {sur }} \cdot\left(R D_{\text {coat }} \cdot D_{\text {coat }}+R D_{\text {Sub }} \cdot D_{\text {Sub }}\right)$

We also want to know whether the secondary waste is solid or liquid and if liquids are introduced by the process whether or not solids may be separated from liquids on-site. If separation of solids and liquids can be done on-site then we can send liquids only to off-site disposal, otherwise both solids and liquids (mixed) will have to be sent off-site resulting in increased costs for dealing with the wastes. This problem is compounded by the fact that the liquids introduced will not only mix with the (possible) solids used in the process but will also mix with the surface being removed adding more costs.

If solids and liquids can be separated on-site, $\operatorname{Sep}=1$ Else $S e p=0$

Total Volume of Solid Waste

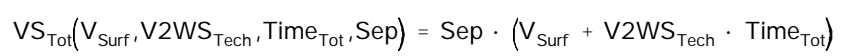

\section{Total Mass of Solid Waste}

$\mathrm{MS}_{\text {Tot }}\left(\mathrm{M}_{\text {Surf }},{\mathrm{V} 2 W \mathrm{~S}_{\text {Tech }}, \mathrm{D} 2 \mathrm{WS}}_{\text {Tech }}, \mathrm{Time}_{\text {Tot }}, \mathrm{Sep}\right)=\mathrm{Sep} \cdot\left(\mathrm{M}_{\text {Surf }}+\mathrm{V} \mathrm{WS}_{\text {Tech }} \cdot \mathrm{D} 2 \mathrm{WS} \mathrm{S}_{\text {Tech }} \cdot\right.$ Time $\left._{\text {Tot }}\right)$ 
Total Volume of Liquid Waste

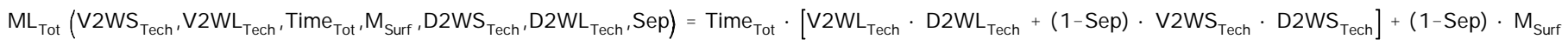

Total Mass of Liquid Waste

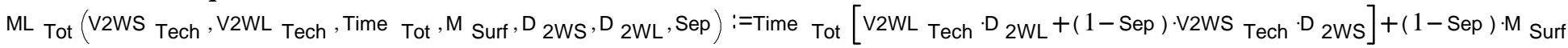

Volume of CH Waste

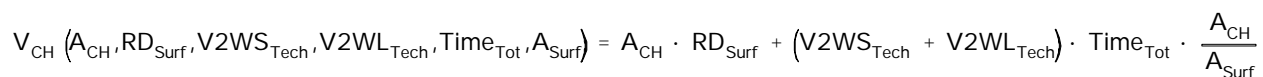

\section{Mass of CH Waste}

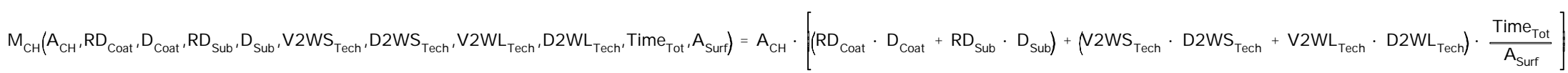

\section{Volume of RH Waste}

$\underset{1}{+} \quad \mathrm{V}_{\text {RH }}\left(\mathrm{A}_{\mathrm{RH}}, \mathrm{RD}_{\text {Surf }}, \mathrm{V} 2 \mathrm{WS}_{\text {Tech }}, \mathrm{V} 2 \mathrm{WL}_{\text {Tech }}, \mathrm{Time}_{\text {Tot }}, \mathrm{A}_{\text {Surf }}\right)=\mathrm{A}_{\mathrm{RH}} \cdot \mathrm{RD}_{\text {Surf }}+\left(\mathrm{V} 2 \mathrm{WS}_{\text {Tech }}+\mathrm{V} 2 \mathrm{WL} \mathrm{L}_{\text {Tech }}\right) \cdot \mathrm{Time}_{\text {Tot }} \cdot \frac{\mathrm{A}_{\mathrm{RH}}}{\mathrm{A}_{\text {Surf }}}$

Mass of RH Waste

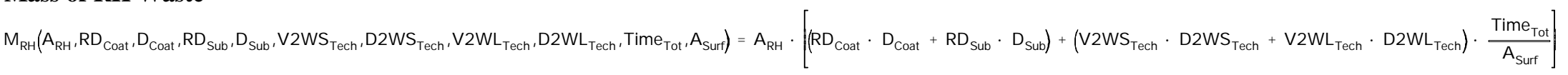

\section{Percentage of Total Waste Volume Which Is CH}

$\mathrm{V} \% \mathrm{CH}\left(\mathrm{VS}_{\mathrm{Tot}}, \mathrm{VL}_{\mathrm{Tot}}, \mathrm{V}_{\mathrm{CH}}\right):=100 \cdot \frac{\mathrm{V}_{\mathrm{CH}}}{\left(\mathrm{VS}_{\mathrm{Tot}}+\mathrm{VL}_{\mathrm{Tot}}\right)}$

\section{Percentage of Total Waste Mass Which Is CH}

$\mathrm{M} \% \mathrm{CH}\left(\mathrm{MS}_{\mathrm{Tot}}, \mathrm{ML}_{\mathrm{Tot}}, \mathrm{M}_{\mathrm{CH}}\right):=100 \frac{\mathrm{M}_{\mathrm{CH}}}{\left(\mathrm{MS}_{\mathrm{Tot}}+\mathrm{ML} \text { Tot }\right)}$ 
Percentage of Total Waste Volume Which Is RH

$\mathrm{V}_{\mathrm{RH}}\left(\mathrm{VS}_{\text {Tot }}, \mathrm{VL}_{\text {Tot }}, \mathrm{V}_{\mathrm{RH}}\right):=100 \frac{\mathrm{V}_{\mathrm{RH}}}{\left(\mathrm{VS}_{\text {Tot }}+\mathrm{VL}_{\text {Tot }}\right)}$

Percentage of Total Waste Mass Which Is RH

$\mathrm{M}_{\mathrm{RH}}\left(\mathrm{MS}_{\mathrm{Tot}}, \mathrm{ML} \mathrm{Tot}_{\mathrm{RH}}, \mathrm{M}_{\mathrm{RH}}\right):=100 \frac{\mathrm{M}_{\mathrm{RH}}}{\left(\mathrm{MS}_{\mathrm{Tot}}+\mathrm{ML}_{\mathrm{Tot}}\right)}$

Now recompute waste volumes and masses for each waste category assuming uniform mixing of contaminates, surface removal media (if any), and surface removal debris in contaminated areas

Mass of Ch Solid Waste

MS $\mathrm{CH}\left(\mathrm{M}_{\mathrm{CH}}, \mathrm{MS}_{\mathrm{Tot}}\right):=\mathrm{MS}$ Tot $\frac{\mathrm{M} \% \mathrm{CH}}{100}$

Mass of CH Liquid Waste

$\mathrm{ML}_{\mathrm{CH}}\left(\mathrm{M}^{\mathrm{C}} \mathrm{CH}, \mathrm{ML}\right.$ Tot $):=\mathrm{ML}$ Tot $\frac{\mathrm{M} \% \mathrm{CH}}{100}$

Mass of RH Solid Waste

MS ${ }_{\mathrm{RH}}\left(\mathrm{M}_{\mathrm{RH}}, \mathrm{MS}_{\text {Tot }}\right):=\mathrm{MS}$ Tot $\frac{\mathrm{M} \% \mathrm{RH}}{100}$

Mass of RH Liquid Waste

$\mathrm{ML} \mathrm{RH}\left(\mathrm{M} \% \mathrm{RH}^{\mathrm{ML}}, \mathrm{ML}\right):=\mathrm{ML}$ Tot $\frac{\mathrm{M} \% \mathrm{RH}}{100}$

Mass of CD Solid Waste

MS $\mathrm{CD}$ (MS Tot $_{\mathrm{CH}}$, MS $\mathrm{RH}_{\mathrm{RH}}$ ) :=MS $\mathrm{Tot}^{-\mathrm{MS}} \mathrm{CH}^{-\mathrm{MS}} \mathrm{RH}$ 
Volume of CH Solid Waste

vS $_{\mathrm{CH}}\left(\mathrm{V}_{\mathrm{CH}}\right.$, VS $\left.{ }_{\mathrm{Tot}}\right):=\mathrm{VS}$ Tot $\frac{\mathrm{V} \% \mathrm{CH}}{100}$

Volume of CH Liquid Waste

$\mathrm{VL}_{\mathrm{CH}}\left(\mathrm{V}_{\mathrm{CH}}, \mathrm{VL} \mathrm{Tot}\right):=\mathrm{VL} \mathrm{Tot}_{\mathrm{V}} \frac{\mathrm{V} \mathrm{CH}_{\mathrm{CH}}}{100}$

Volume of RH Solid Waste

$\mathrm{VS}_{\mathrm{RH}}\left(\mathrm{V}_{\mathrm{RH}}, \mathrm{VS} \mathrm{Tot}\right):=\mathrm{VS}$ Tot $\frac{\mathrm{V} \%_{\mathrm{RH}}}{100}$

Volume of RH Liquid Waste

1
1
1

$\mathrm{VL}_{\mathrm{RH}}\left(\mathrm{V}_{\mathrm{RH}}, \mathrm{VL} \mathrm{Tot}_{\mathrm{T}}\right):=\mathrm{VL} \mathrm{Tot}_{\mathrm{R}} \cdot \frac{\mathrm{V} \%_{\mathrm{RH}}}{100}$

Volume of CD Solid Waste

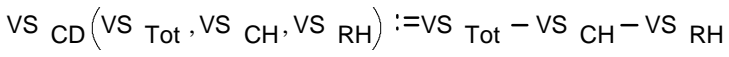

Transportation Costs

If on-site disposal is used for solids, OnSite $=1$ else OnSite $=0$

If Truck is used as transport style, Truck=1 else Truck=0

Some of these values will change:

MSTruck $_{\mathrm{CH}}=44000 \mathrm{lb} \quad$ MLTruck $_{\mathrm{CH}}=21688 \mathrm{lb} \quad$ CostMile $_{\mathrm{CHTruck}}=10 \quad$ Maint $_{\mathrm{CHT} \text { ruck }}=100$

\section{Contact Handled Waste Off-Site Trucking Costs}

$\mathrm{CTOff}_{\mathrm{CH}}\left(\mathrm{MS}_{\mathrm{CH}}, \mathrm{ML}_{\mathrm{CH}}\right.$, Dist $_{\text {offCH }}$, Truck, OnSite $)=\operatorname{Truck} \cdot\left[\frac{\mathrm{ML}_{\mathrm{CH}}}{\text { MLTruck }_{\mathrm{CH}}}+(1-\right.$ OnSite $\left.) \cdot\left(\frac{\mathrm{MS}_{\mathrm{CH}}}{\text { MSTruck }_{\mathrm{CH}}}\right)\right] \cdot\left(\right.$ CostMile $_{\mathrm{CHTruck}} \cdot$ Dist $_{\text {offCH }}+$ Maint $\left._{\mathrm{CHTruck}}\right)$ 


\section{Contact Handled Waste On-Site Trucking Costs}

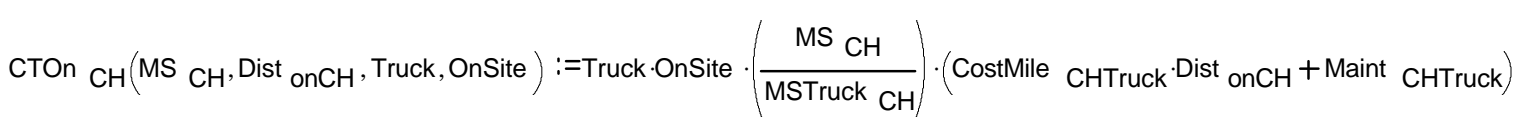

Some of these values will change:

MSRail $_{C H}=44000 \mathrm{lb} \quad$ MLRail $_{C H}=18240 \mathrm{lb} \quad$ CostMile $_{\text {Rail }}=8 \quad$ Maint $_{\text {Rail }}=100$

\section{Contact Handled Waste Rail Transportation Costs}

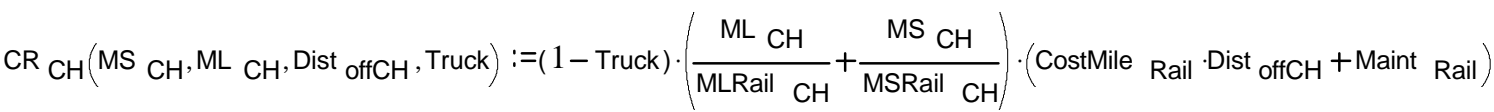

Some of these values will change:

MSTruck $_{\mathrm{RH}}=13400 \mathrm{lb} \quad$ MLTruck $_{\mathrm{RH}}=6422 \mathrm{lb} \quad$ CostMile $_{\mathrm{RHTruck}}=15 \quad$ Maint $_{\mathrm{RHTruck}}=100$

\section{Remote Handled Waste Off-Site Trucking Costs}

$\mathrm{CTOff}_{\mathrm{RH}}\left(\mathrm{MS}_{\mathrm{RH}}, \mathrm{ML}_{\mathrm{RH}}\right.$, Dist $_{\text {offRH }}$, Truck, OnSite $)=$ Truck $\mid \frac{\mathrm{ML}_{\mathrm{RH}}}{\text { MLTruck }_{\mathrm{RH}}}+(1-$ OnSite $) \cdot\left(\frac{M_{\mathrm{RH}}}{\text { MSTruck }_{\mathrm{RH}}}\right) \mid \cdot\left(\right.$ CostMile $_{\mathrm{RHTruck}} \cdot$ Dist $_{\text {offRH }}+$ Maint $\left._{\mathrm{RHTruck}}\right)$

\section{Remote Handled Waste On-Site Trucking Costs}

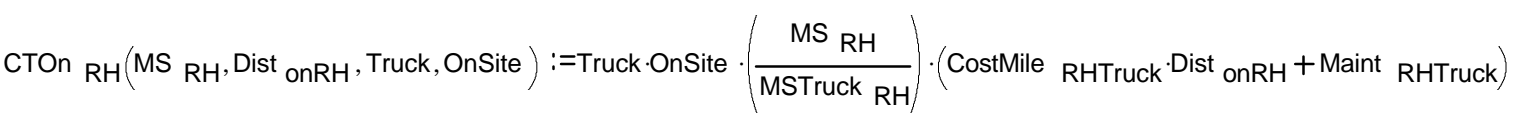

Some of these values will change:

MSTruck $_{\mathrm{CD}}=44000 \mathrm{lb} \quad$ CostMile $_{\mathrm{CDTruck}}=10 \quad$ Maint $_{\mathrm{CDTruck}}=100$

\section{Construction and Demolition Waste On-Site Trucking Costs}

CTOn $\mathrm{CD}\left(\mathrm{MS}_{\mathrm{CD}}\right.$, Dist $\mathrm{CD}$, Truck $):=$ Truck $\cdot\left(\frac{\mathrm{MS} \mathrm{CD}}{\text { MSTruck } \mathrm{CD}}\right) \cdot\left(\right.$ CostMile $\mathrm{CD}_{\text {Truck }}{ }^{\text {Dist }} \mathrm{CD}+$ Maint $\left.\mathrm{CDTruck}\right)$ 


\section{PERFORMANCE INDICES}

\section{Surface Removal}

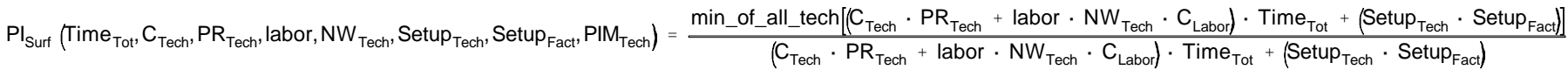

\section{Transport}

PI Transport (

\section{Waste Disposal}

Included are factors that give each term of the sum weight based on the undesirability of producing that type of waste. These may be based on relative disposal costs. (Disposal factors were taken from EM Task 21 Semiannual for 4-1-98 to 9-30-98.)
fS $\mathrm{CH}:=60$
$\mathrm{fL}_{\mathrm{CH}}:=60$
fS $_{\mathrm{RH}}:=300$
$\mathrm{fL}_{\mathrm{RH}}:=300$
fS $C D:=8.18$

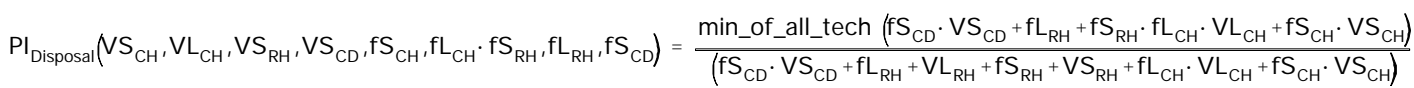

\section{Safety}

$\mathrm{PI}_{\text {Satery }}$ (Use_normalized_values_from_the_dataset)

\section{Maintenance}

$\mathrm{PI}_{\text {Maint }}$ (Use_normalized_values_from_the_dataset)

\section{Overall Performance Index}

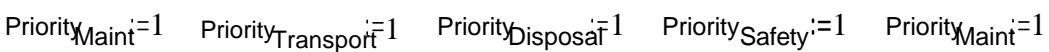

$\mathrm{PI}_{\text {Overall }}\left(\mathrm{PI}_{\text {Surf }}, \mathrm{PI}_{\text {Transport }}, \mathrm{PI}_{\text {Disposal, }}, \mathrm{PI}_{\text {Maint }}\right)=\frac{\text { Priority }_{\text {Surf }} \cdot \mathrm{PI}_{\text {Surf }}+\text { Priority }_{\text {Transport }} \cdot \mathrm{PI}_{\text {Transport }}+\text { Priority }_{\text {Disposal }} \cdot \mathrm{PI}_{\text {Disposal }}+\text { Priority }_{\text {Safety }} \cdot \mathrm{PI}_{\text {Safety }}+\text { Priority }_{\text {Maint }} \cdot \mathrm{PI}_{\text {Maint }}}{\text { max_of_all_tech (Priority }}$ 


\section{APPENDIX F}

\section{SURFACE DECONTAMINATION ASSISTANCE SENSITIVITY ANALYSES}




\section{SURFACE DECONTAMINATION ASSISTANCE SENSITIVITY ANALYSES}

Sensitivity analyses were performed to determine the effectiveness of the Surface Decontamination Assistance (SDA) model design. The first step in the process was to create a reasonable matrix composed of scenarios that would test SDA outputs for individual PIs and the overall PI as well as provide data to explore the rigor of the model and its programming implementation. During this process, the model was amended and programming errors identified and repaired. To examine the dynamics of the system by varying each input parameter individually at two levels (for example, depth of coating at 0.05 and 1 in.) would require a factorial design containing more than 8100 scenarios, a daunting task. Therefore, each input datum was evaluated for its importance in affecting model outputs. Those expected to have greater significance were varied in the test matrix. The unabridged matrix is shown in Table F1.

Figures F1 through F6 illustrate the output information from the software. The predicted PIs from Scenario 3 are used in the examples. As the graphs indicate, the specific technologies recommended by the SDA software vary by PI category. As elements of the input data change, the ranking of technologies may change as well. The exceptions to this expectation are the EHS and IOM PIs whose data come directly from the performance dataset and undergo no manipulation prior to the calculation of the PI itself.

An objective of the sensitivity analyses was to show that the ranking of technologies for any given PI could change resultant to changes in scenario inputs. A change in depth of coating, for example, can show a corresponding shift in technologies suggested for exploration with respect to the surface removal PI. This is indicated by the comparison of Scenarios 11 and 13 in Figure F7, where mechanical scabbling and high-pressure water versus microwave perform well for Scenarios 11 and 13, respectively. Figure F8 illustrates variations in recommended technologies for better transportation values based on the difference in depth of coating, on-site separation of solids from liquids, and the distribution of waste types between Scenarios 11 and 13. While the carbon dioxide laser and a few blasting technologies receive favorable results in both scenarios, the waste disposal PI in others such as drilling spalling, scarification MOOSE, and squirrel scabbler vary greatly in value.

An example of input effects on rankings for waste disposal is the comparison of Scenarios 1 and 5 in Figure F9, which vary only in depth of coating. The relative performance of some technologies, such as soft media blasting, improved as the depth of coating increased. Figure F10 shows a different result for waste disposal based on the depth of concrete substrate removed. In Scenario 1, no substrate is removed. In contrast, Scenario 2 has the same amount of coating to eliminate, but also includes the removal of 6 in. of concrete substrate, which must be disposed. As can be seen in the graph, the requirement to remove substrate as well as the surface eliminates some technologies from consideration.

An additional parameter limiting the choice of technologies is the presence of hard-to-reach areas to be decontaminated. This is evident in Figure F11, which compares the surface 
TABLE F1

Sensitivity Analysis Test Matrix

\begin{tabular}{|c|c|c|c|c|c|c|c|c|c|c|c|c|c|c|c|c|c|c|c|c|c|c|c|c|}
\hline$\underline{\text { Scenario }}$ & $\begin{array}{c}\text { Surface } \\
\text { Tyle }\end{array}$ & $\begin{array}{l}\text { Substrate } \\
\text { Material } \\
\end{array}$ & $\begin{array}{l}\text { Total } \\
\text { Area } \\
\end{array}$ & $\begin{array}{c}\% \\
\text { Hard to } \\
\text { Reach } \\
\end{array}$ & $\begin{array}{c}\text { Thickness } \\
\text { of } \\
\text { Coating, } \\
\text { in. }\end{array}$ & $\begin{array}{c}\text { Substratate } \\
\text { Removal } \\
\text { Depth, in. }\end{array}$ & Contaminants & $\begin{array}{c}\begin{array}{c}\text { On-Site } \\
\text { Separation }\end{array} \\
\end{array}$ & $\begin{array}{c}\% \\
\text { Constructio } \\
\mathbf{n} \text { and } \\
\text { Demolition } \\
\text { Waste } \\
\end{array}$ & $\begin{array}{c}\% \\
\text { Contact } \\
\text { Handle } \\
\text { d Waste } \\
\end{array}$ & $\begin{array}{l}\% \text { Area } \\
\text { Remote } \\
\text { Handle } \\
\text { d Waste }\end{array}$ & $\begin{array}{c}\text { Style of } \\
\text { Transpor } \\
\mathbf{t}\end{array}$ & $\begin{array}{c}\text { On- } \\
\text { Site } \\
\text { Storag } \\
\text { e of } \\
\text { solids } \\
\end{array}$ & Tran & sportatio & n Informa & $\mathbf{C H}$ & C\&D & $\begin{array}{c}\text { Technology } \\
\text { Selection } \\
\end{array}$ & $\begin{array}{c}\text { Priority } \\
\text { Ranking } \\
\\
\\
\text { Environmental, } \\
\text { Health, \& } \\
\text { Safety } \\
\end{array}$ & $\begin{array}{c}\text { Operation, } \\
\text { Maintenance, } \\
\text { and } \\
\text { Reliability } \\
\end{array}$ & $\begin{array}{c}\text { Removal } \\
\text { Cost }\end{array}$ & $\begin{array}{c}\text { Transportatio } \\
\text { n Cost }\end{array}$ & $\begin{array}{c}\text { Disposal } \\
\text { Cost }\end{array}$ \\
\hline & & & & & & & & & & & & & & Off-Site & On-Site & Off-Site & On-Site & & & & & & & \\
\hline 1 & Floors & Concrete & 3000 & 0 & 0.05 & 0 & All & No & 20 & 60 & 20 & Truck & No & 1500 & 10 & 1500 & 10 & 40 & All & 6 & 4 & 2 & 4 & 6 \\
\hline 2 & Floors & Concrete & 3000 & 0 & 0.05 & 6 & All & No & 20 & 60 & 20 & Truck & No & 1500 & 10 & 1500 & 10 & 40 & All & 6 & 4 & 2 & 4 & 6 \\
\hline $2 \mathrm{a}$ & Floors & Concrete & 3000 & 0 & 0.05 & 6 & All & No & 20 & 60 & 20 & Rail & No & 1500 & 10 & 1500 & 10 & 40 & All & 6 & 4 & 2 & 4 & 6 \\
\hline 3 & Floors & Concrete & 3000 & 0 & 0.1 & 0 & All & No & 20 & 60 & 20 & Truck & No & 2000 & 30 & 200 & 5 & 2 & All & 6 & 4 & 2 & 4 & 6 \\
\hline 4 & Floors & Concrete & 3000 & 0 & 0.1 & 6 & All & No & 20 & 60 & 20 & Truck & Yes & 2000 & 30 & 200 & 5 & 2 & All & 6 & 4 & 2 & 4 & 6 \\
\hline 5 & Floors & Concrete & 3000 & 0 & 0.95 & 0 & All & No & 20 & 60 & 20 & Truck & No & 1500 & 10 & 1500 & 10 & 40 & All & 5 & 5 & 5 & 5 & 5 \\
\hline 6 & Floors & Concrete & 3000 & 0 & 0.95 & 6 & Heavy metals & No & 0 & 100 & 0 & Rail & No & 1500 & 10 & 1500 & 10 & 40 & All & 6 & 4 & 2 & 4 & 6 \\
\hline 7 & Floors & Concrete & 3000 & 40 & 0.05 & 0 & Heavy metals & No & 20 & 60 & 20 & Rail & No & 1500 & 10 & 1500 & 10 & 40 & All & 6 & 4 & 2 & 4 & 6 \\
\hline 8 & Floors & Concrete & 3000 & 40 & 0.05 & 6 & All & Yes & 20 & 60 & 20 & Rail & No & 1500 & 10 & 1500 & 10 & 40 & All & 6 & 4 & 2 & 4 & 6 \\
\hline 9 & Floors & Concrete & 3000 & 40 & 0.95 & 0 & All & No & 20 & 60 & 20 & Truck & No & 1500 & 10 & 1500 & 10 & 40 & All & 6 & 4 & 2 & 4 & 6 \\
\hline 10 & Floors & Concrete & 3000 & 40 & 0.95 & 6 & All & No & 20 & 60 & 20 & Truck & No & 1500 & 10 & 1500 & 10 & 40 & All & 6 & 4 & 2 & 4 & 6 \\
\hline 11 & Floors & Concrete & 20000 & 0 & 0.05 & 0 & Heavy metals & Yes & 0 & 100 & 0 & Truck & No & 1500 & 10 & 1500 & 10 & 40 & All & 6 & 4 & 2 & 4 & 6 \\
\hline 11a & Floors & Concrete & 20000 & 0 & 0.05 & 0 & Heavy metals & No & 20 & 60 & 20 & Truck & No & 1500 & 10 & 1500 & 10 & 40 & All & 6 & 4 & 2 & 4 & 6 \\
\hline 12 & Floors & Concrete & 20000 & 0 & 0.05 & 6 & All & No & 20 & 60 & 20 & Truck & No & 1500 & 10 & 1500 & 10 & 40 & All & 6 & 4 & 2 & 4 & 6 \\
\hline 13 & Floors & Concrete & 20000 & 0 & 0.95 & 0 & All & No & 20 & 60 & 20 & Truck & No & 1500 & 10 & 1500 & 10 & 40 & All & 6 & 4 & 2 & 4 & 6 \\
\hline 14 & Floors & Concrete & 20000 & 0 & 0.95 & 6 & All & No & 20 & 60 & 20 & Truck & Yes & 2000 & 30 & 200 & 5 & 2 & All & 6 & 4 & 2 & 4 & 6 \\
\hline $14 a$ & Floors & Concrete & 20000 & 0 & 0.95 & 6 & All & Yes & 20 & 60 & 20 & Truck & Yes & 2000 & 30 & 200 & 5 & 2 & All & 6 & 4 & 2 & 4 & 6 \\
\hline 15 & Floors & Concrete & 20000 & 40 & 0.05 & 0 & All & Yes & 20 & 60 & 20 & Truck & No & 1500 & 10 & 1500 & 10 & 40 & All & 6 & 4 & 2 & 4 & 6 \\
\hline 16 & Floors & Concrete & 20000 & 40 & 0.05 & 6 & Heavy metals & Yes & 20 & 60 & 20 & Truck & No & 1500 & 10 & 1500 & 10 & 40 & All & 6 & 4 & 2 & 4 & 6 \\
\hline 17 & Floors & Concrete & 20000 & 40 & 0.95 & 0 & All & Yes & 20 & 60 & 20 & Truck & No & 1500 & 10 & 1500 & 10 & 40 & All & 6 & 4 & 2 & 4 & 6 \\
\hline 18 & Floors & Concrete & 20000 & 40 & 0.95 & 6 & All & Yes & 0 & 100 & 0 & Truck & No & 1500 & 10 & 1500 & 10 & 40 & All & 6 & 4 & 2 & 4 & 6 \\
\hline 19 & Walls & Concrete & 20000 & 0 & 0.95 & 6 & Heavy metals & No & 20 & 60 & 20 & Truck & No & 1500 & 10 & 1500 & 10 & 40 & All & 6 & 4 & 2 & 4 & 6 \\
\hline 20 & Walls & Steel & 20000 & 0 & 0.95 & 0 & Heavy metals & Yes & 20 & 60 & 20 & Truck & No & 1500 & 10 & 1500 & 10 & 40 & All & 6 & 4 & 2 & 4 & 6 \\
\hline 21 & Ceilings & Concrete & 20000 & 40 & 0.95 & 6 & Heavy metals & No & 20 & 60 & 20 & Truck & Yes & 2000 & 30 & 200 & 5 & 2 & All & 6 & 4 & 2 & 4 & 6 \\
\hline $21 \mathrm{a}$ & Ceilings & Concrete & 20000 & 40 & 0.95 & 6 & Heavy metals & No & 20 & 60 & 20 & Truck & No & 2000 & 30 & 200 & 5 & 2 & All & 5 & 5 & 5 & 5 & 5 \\
\hline 22 & Ceilings & Steel & 20000 & 40 & 0.1 & 0 & Heavy metals & Yes & 20 & 60 & 20 & Truck & No & 2000 & 30 & 200 & 5 & 2 & All & 6 & 4 & 2 & 4 & 6 \\
\hline
\end{tabular}




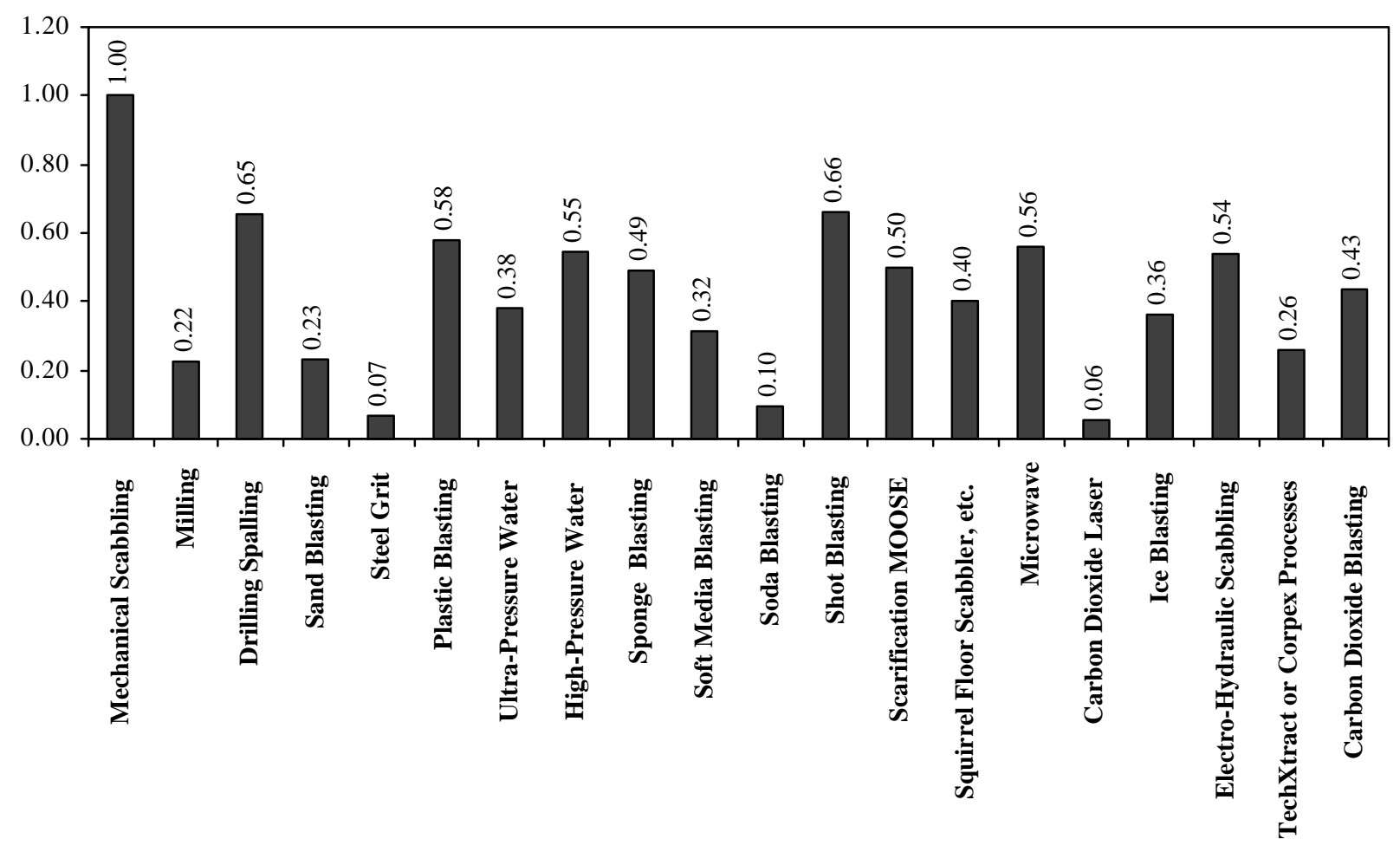

Figure F1. Surface removal performance index for Scenario 3.

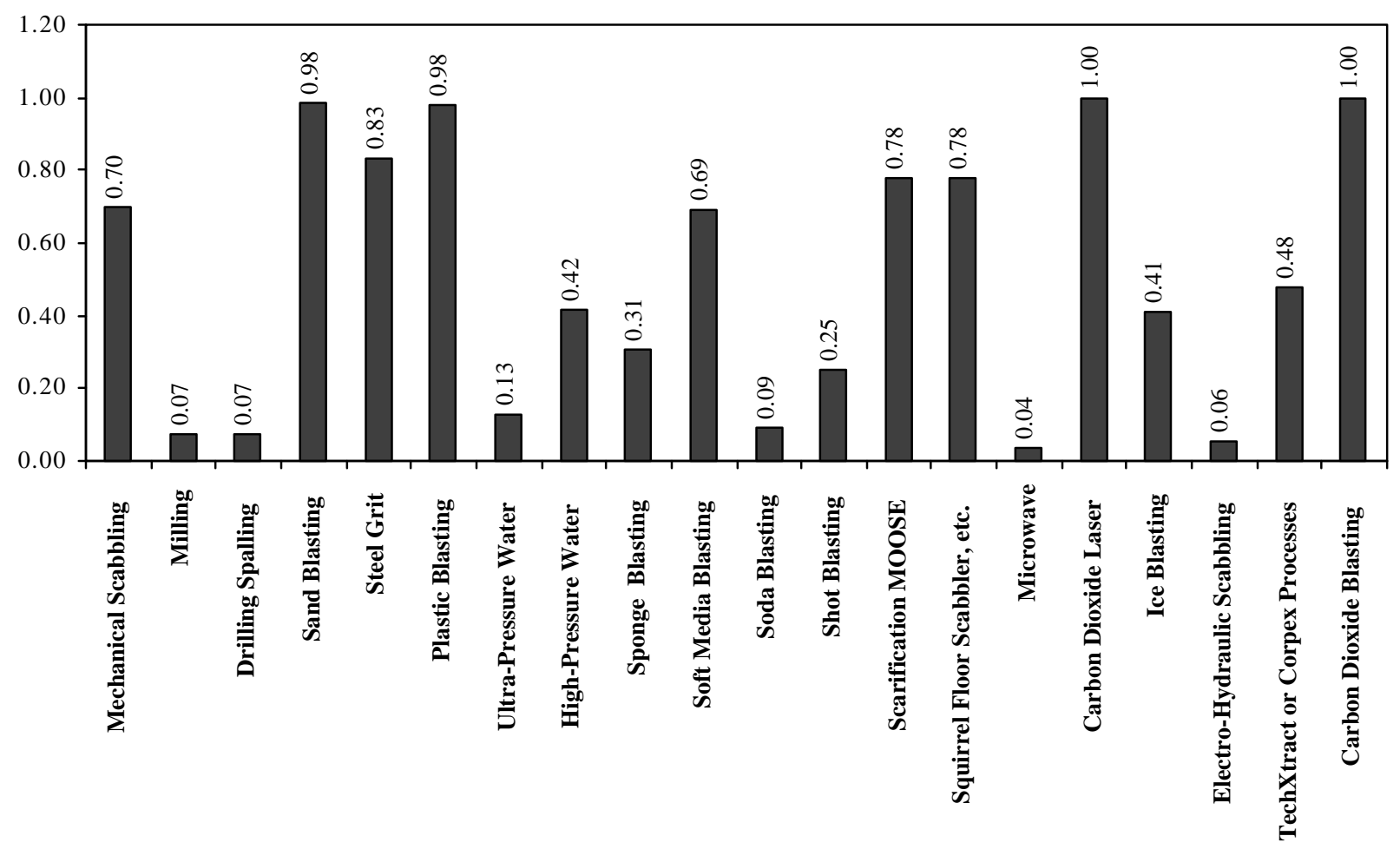

Figure F2. Transport performance index for Scenario 3. 


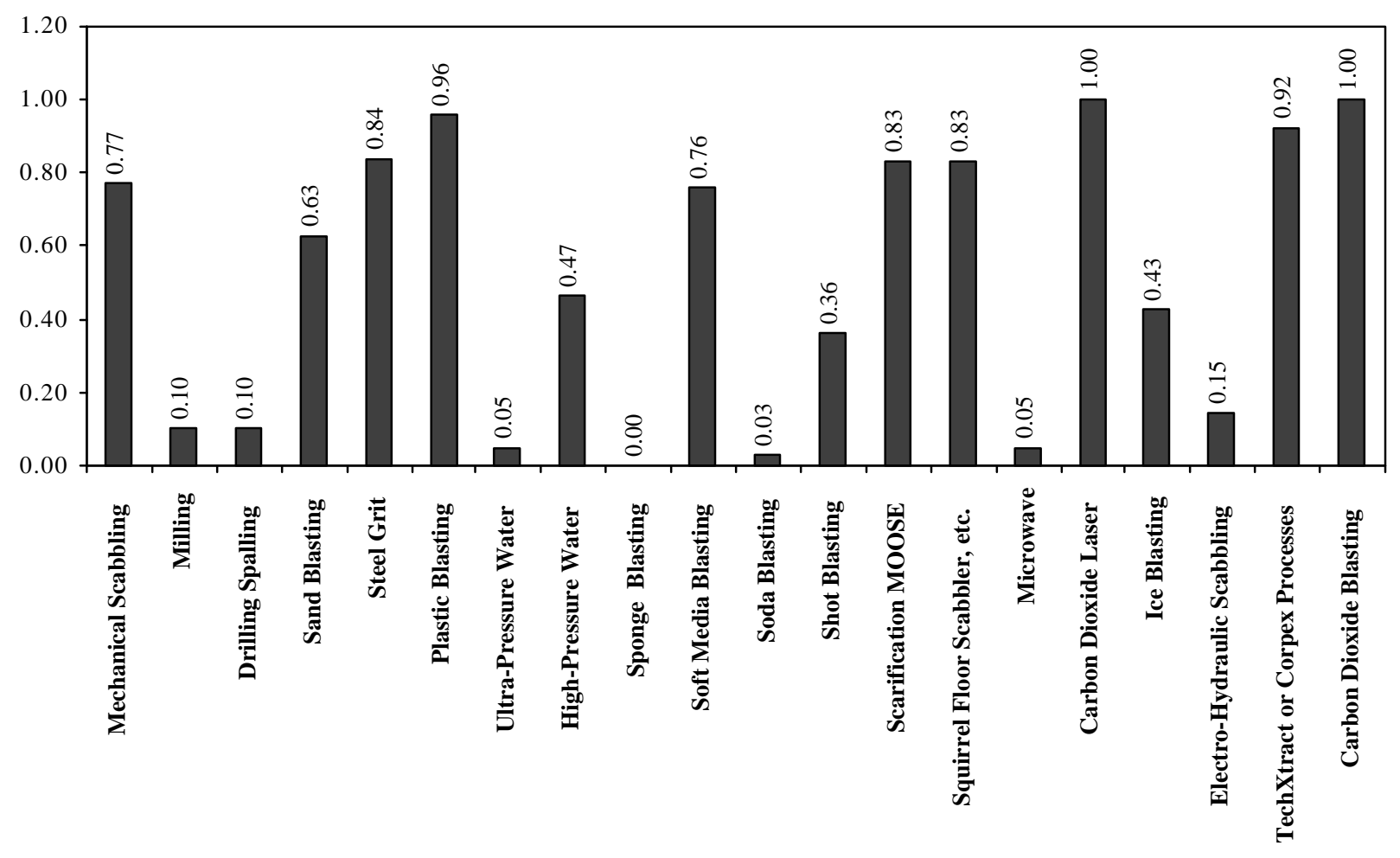

Figure F3. Waste disposal performance index for Scenario 3.

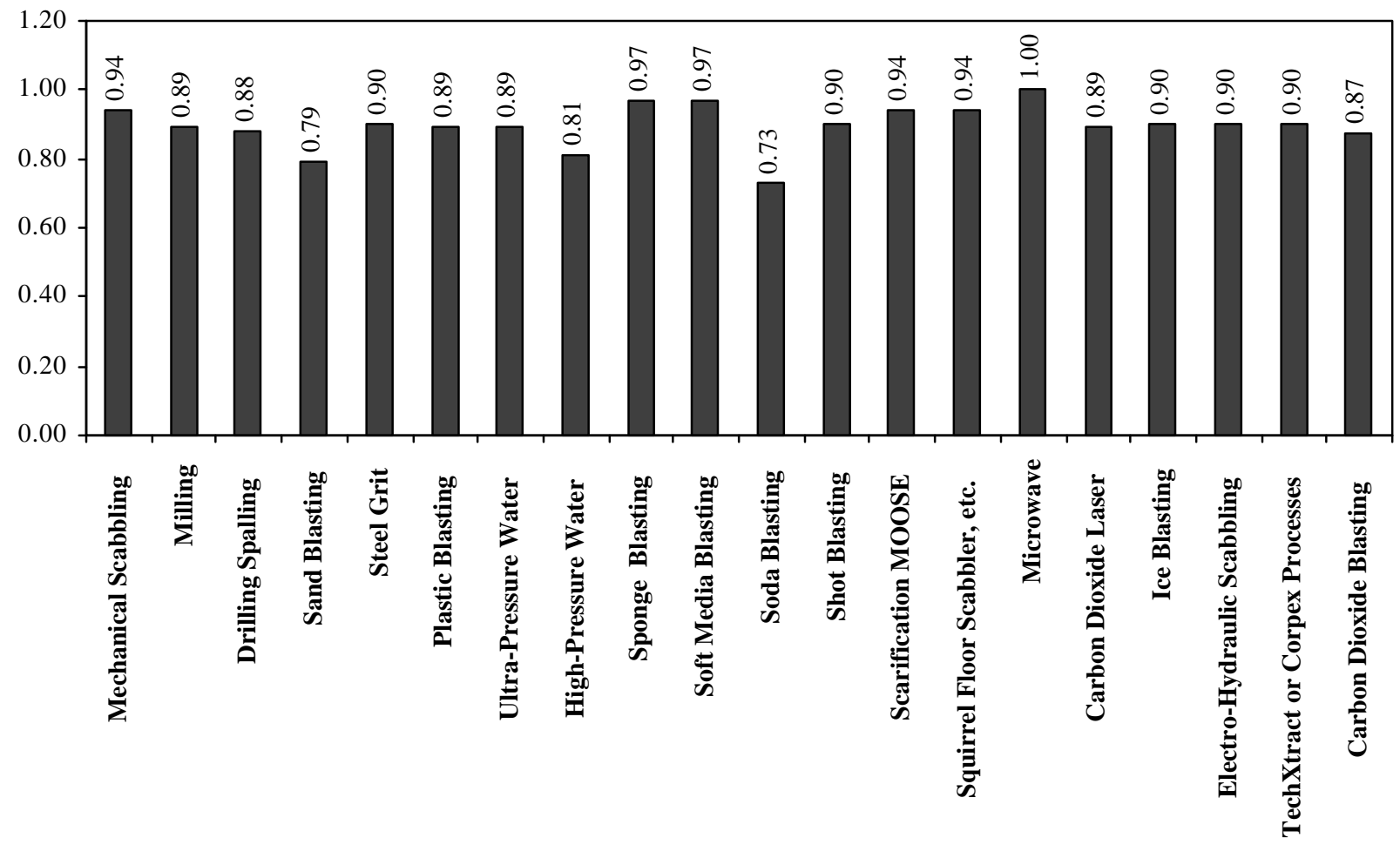

Figure F4. Environment, health, and safety performance index for Scenario 3. 


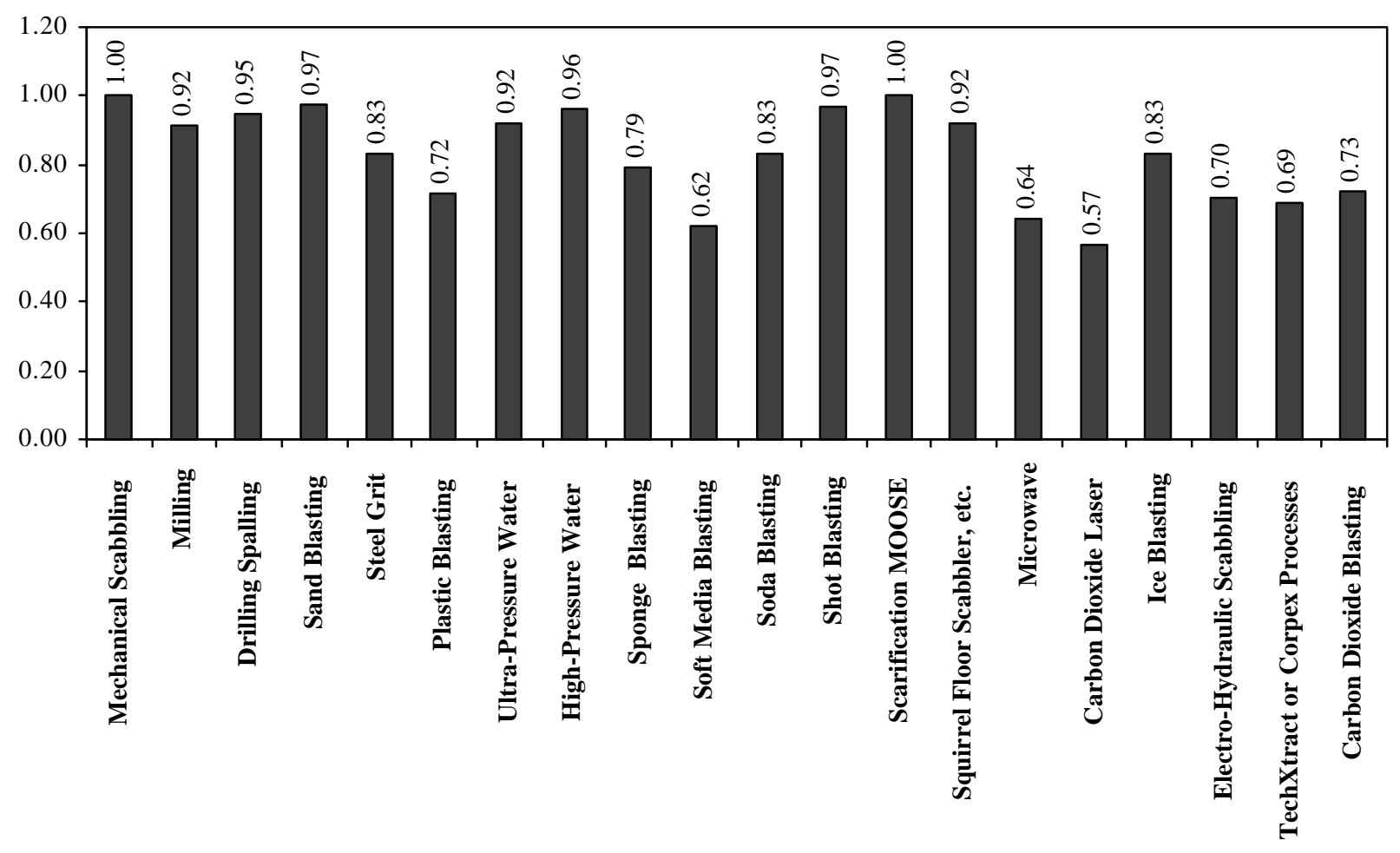

Figure F5. Implementability, operation, and maintenance performance index for Scenario 3.

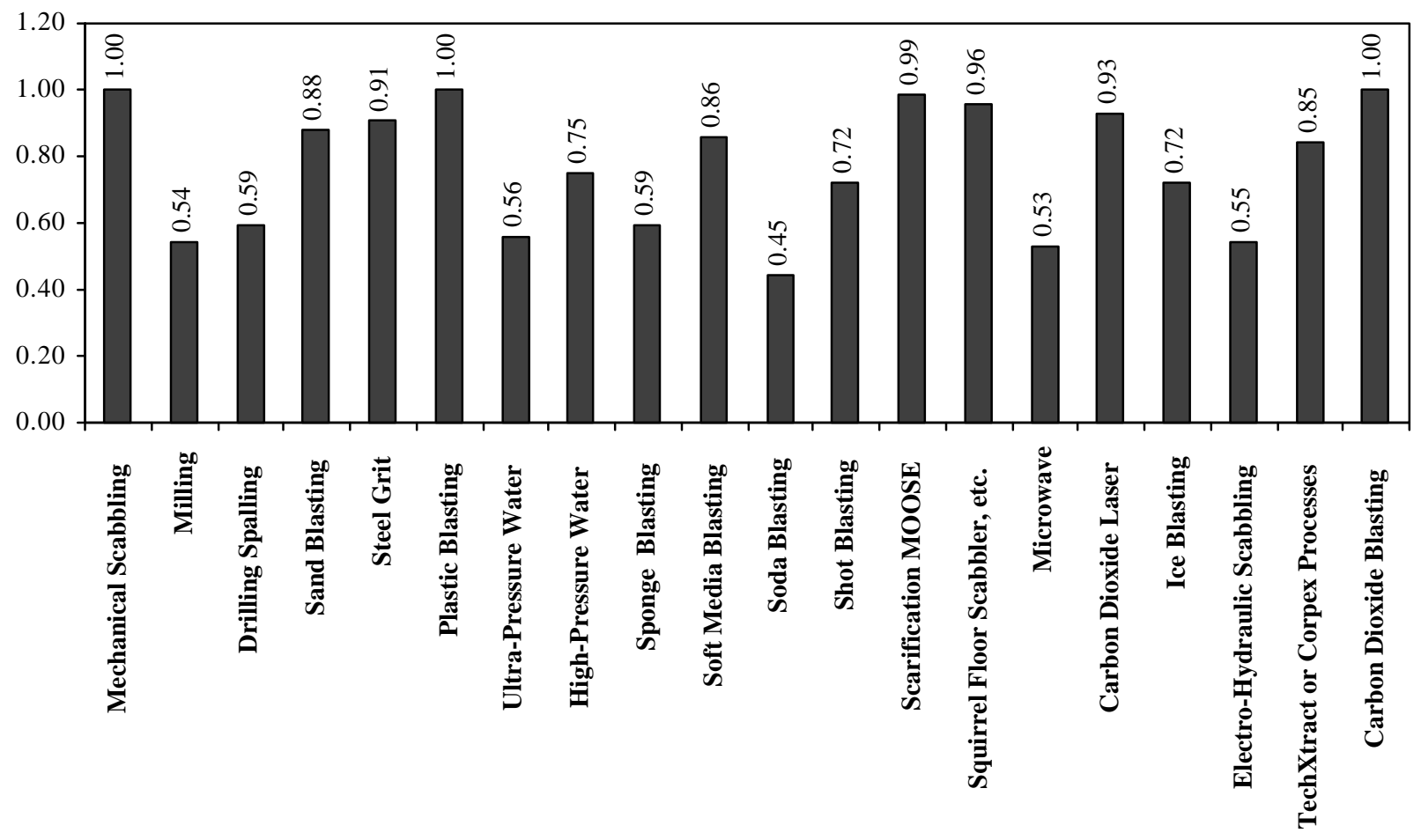

Figure F6. Overall performance index for Scenario 3. 


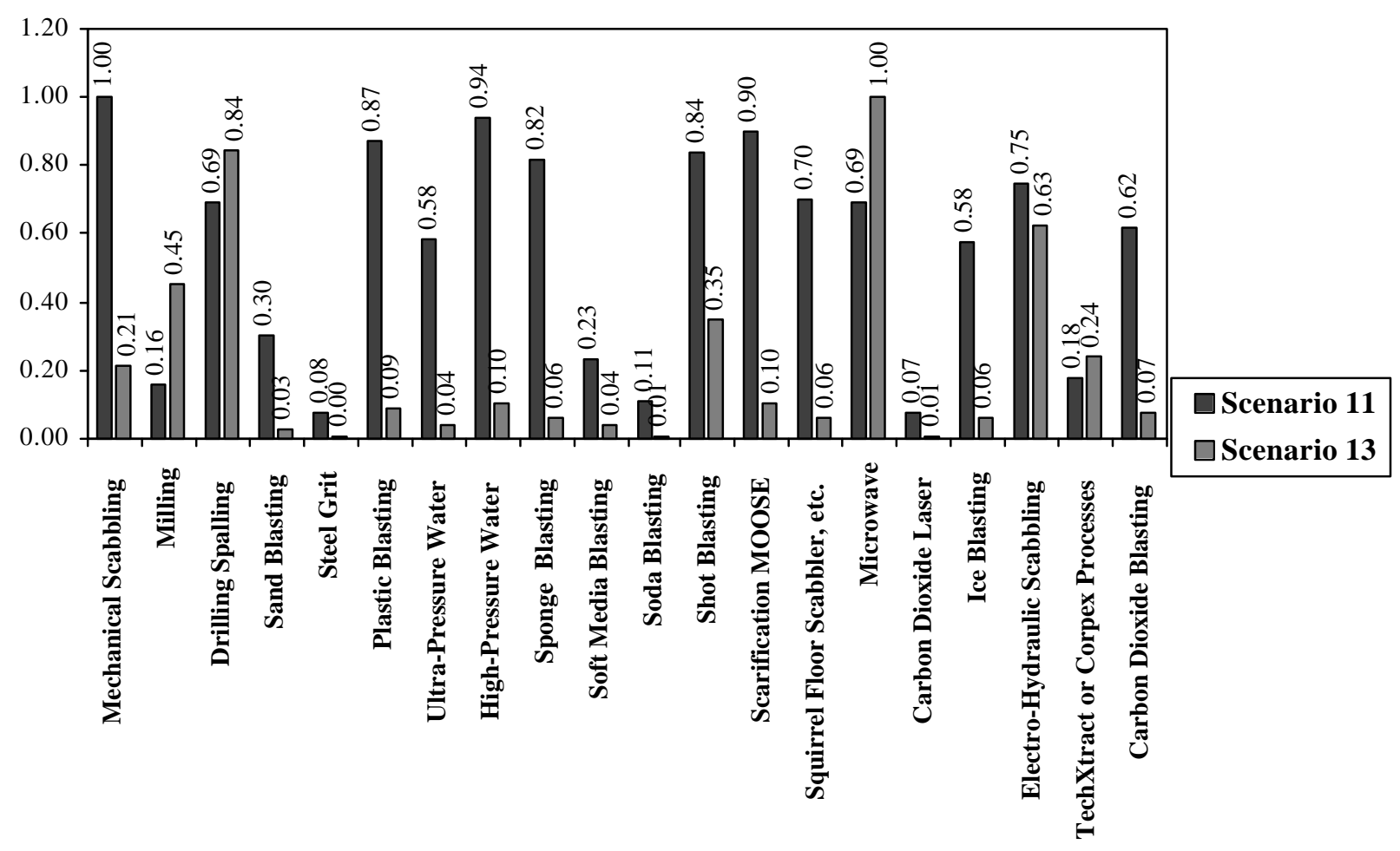

Figure F7. Comparison of surface removal performance indices.

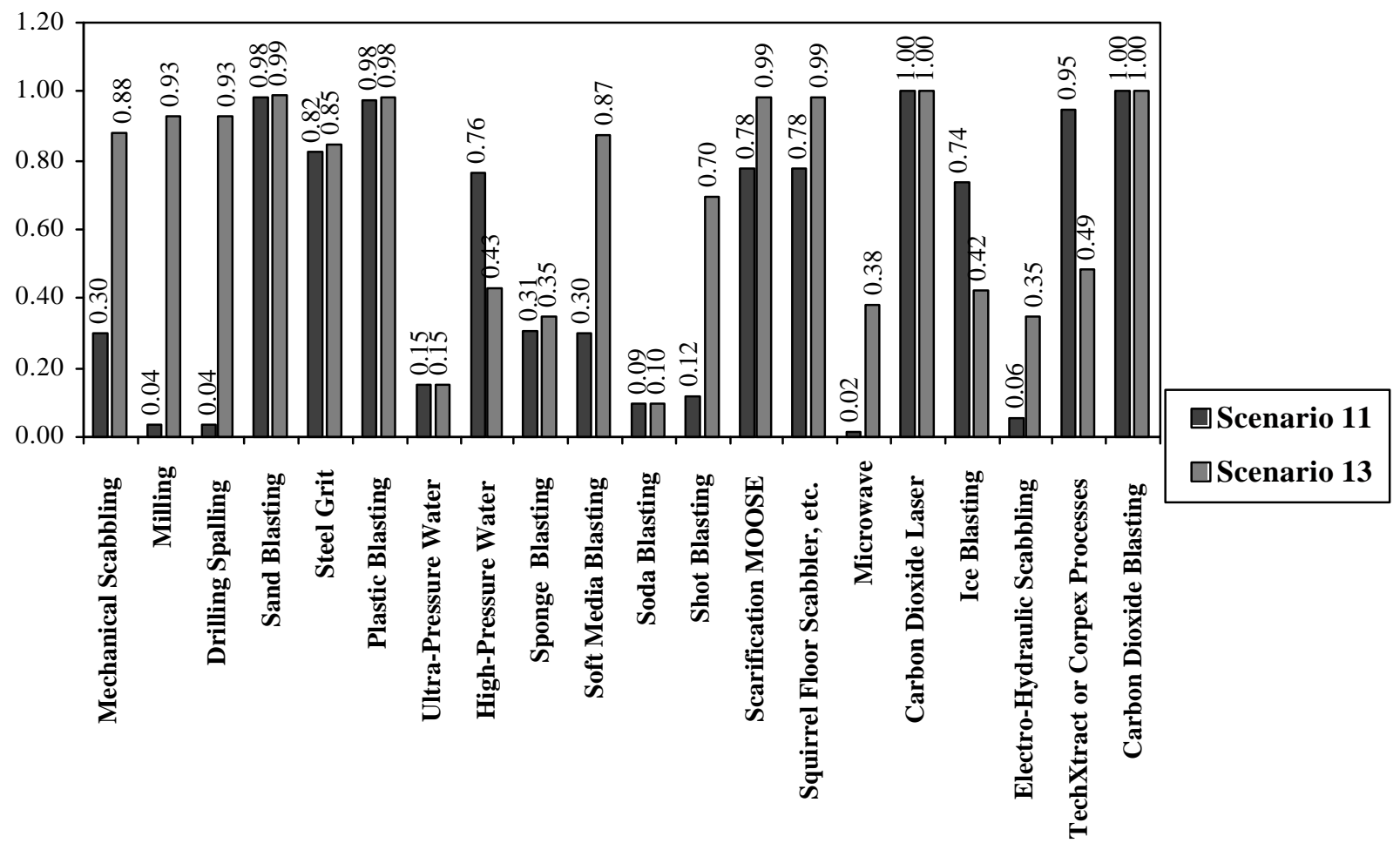

Figure F8. Comparison of transport performance indices. 


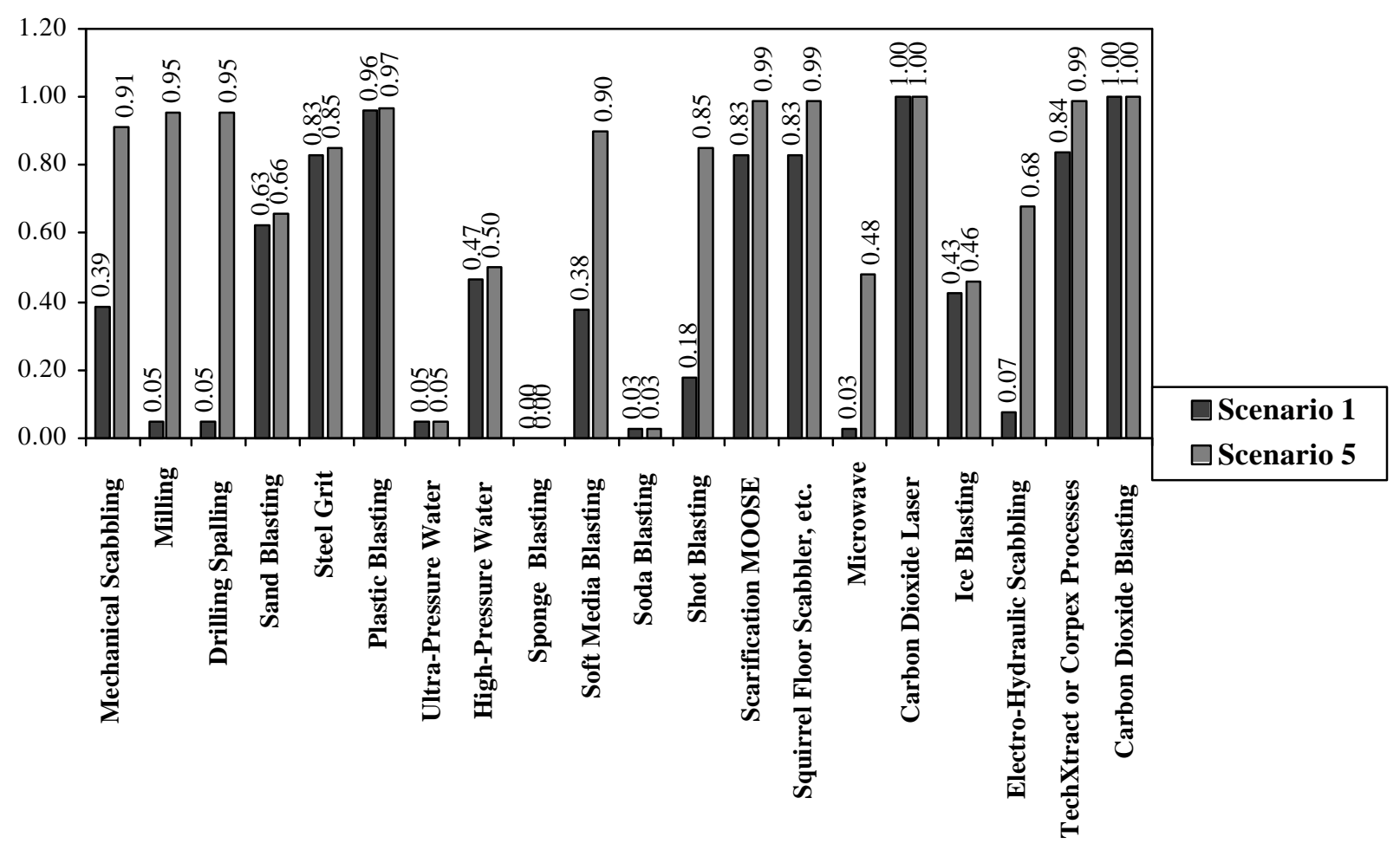

Figure F9. Comparison of waste disposal performance indices.

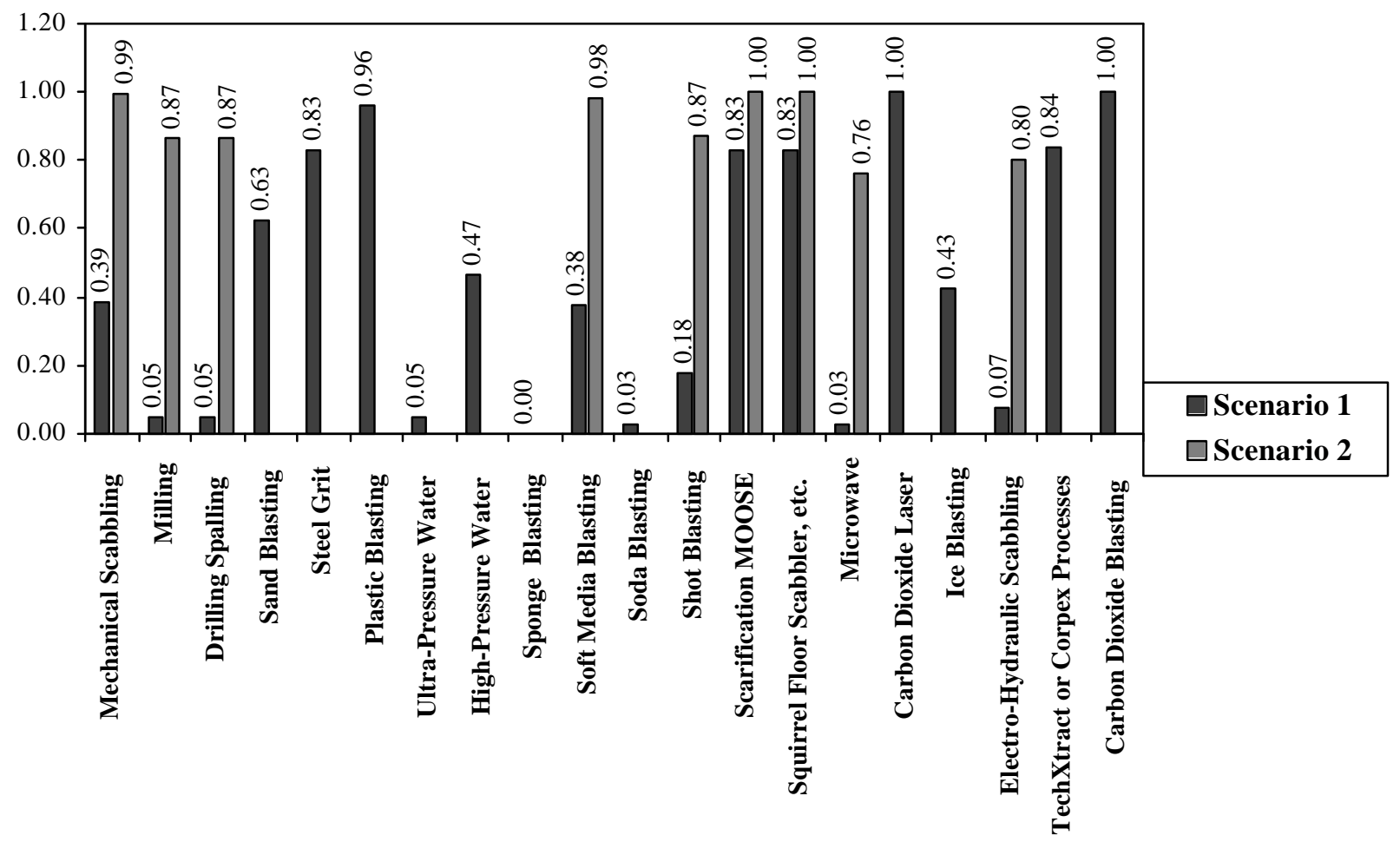

Figure F10. Comparison of waste disposal performance indices. 


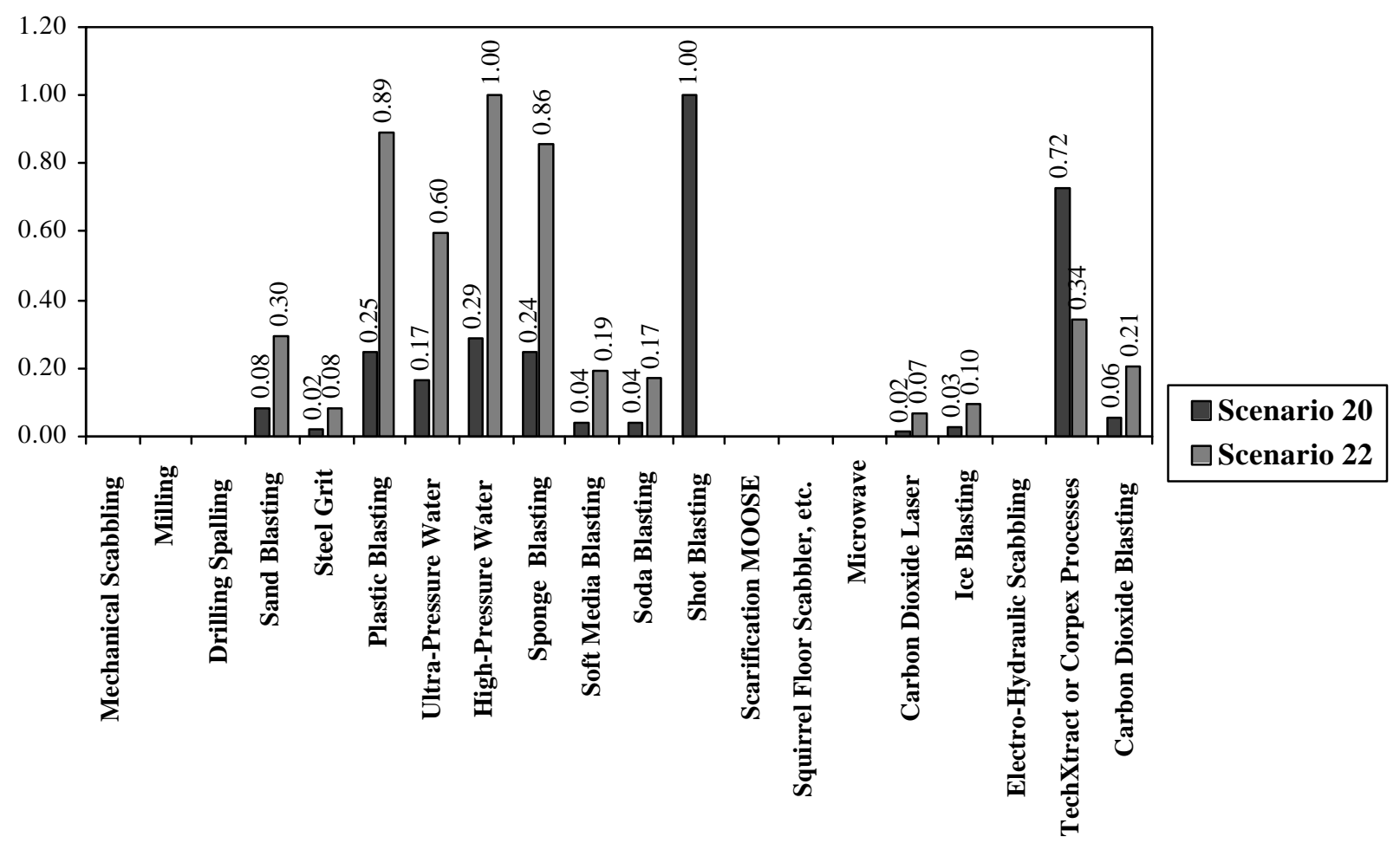

Figure F11. Comparison of surface removal performance indices for scenarios with and without hard-to-reach areas.

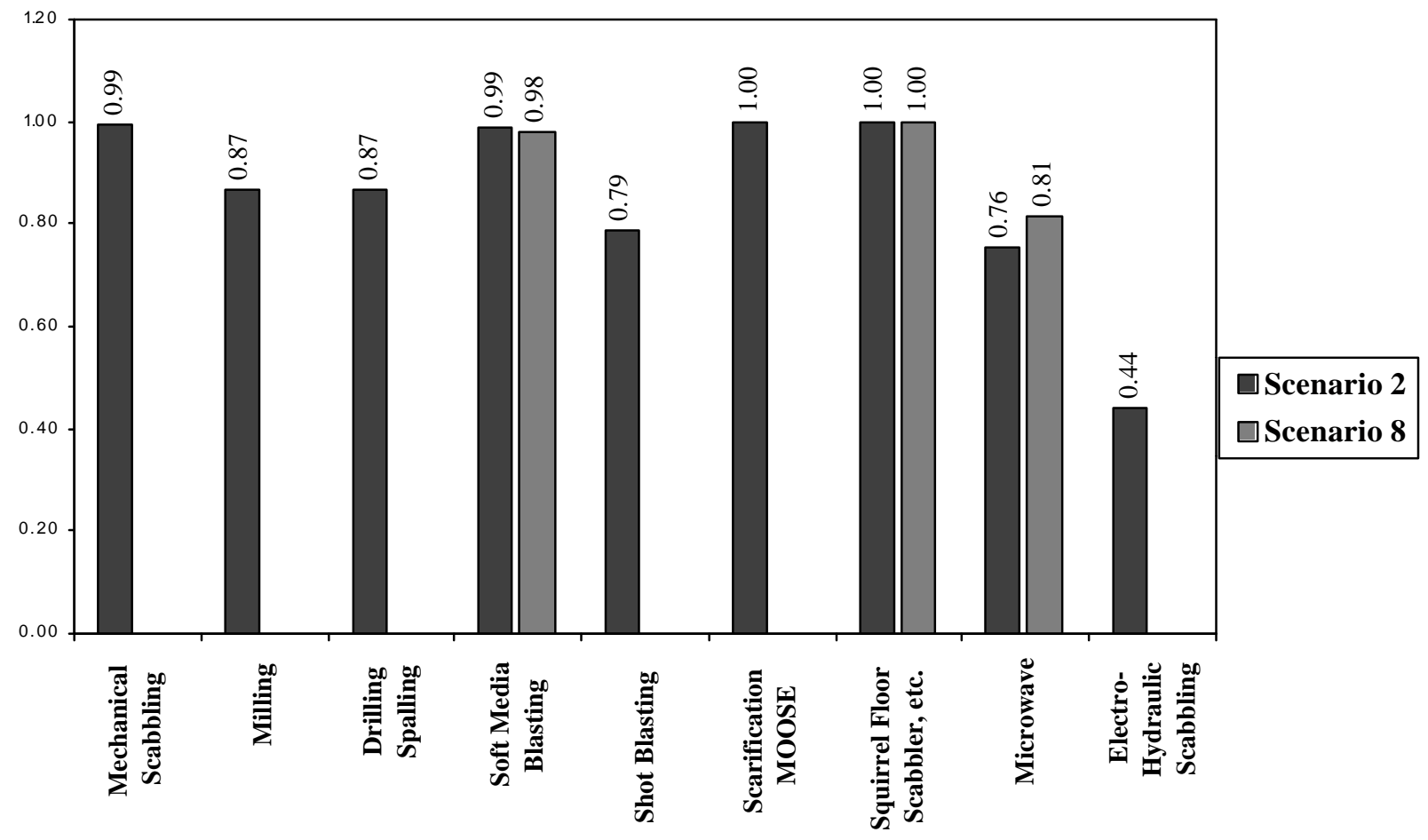

Figure F12. Comparison of transport performance indices for scenarios with and without hard-toreach areas. 
removal PIs from Scenarios 20 and 22. Both of these are coating-removal scenarios for metal substrates. Although the scenarios vary in the capacities to separate and store solids on-site, the only difference pertinent to the surface removal PI is in the hard-to-reach component. A similar comparison for concrete substrate removal scenarios is illustrated in Figure F12, where Scenarios 2 and 8 are compared. Scenario 8, with $40 \%$ of its area hard to reach and requiring substrate removal, has only three technologies available for comparison.

A comparison of the overall PI is shown in Figure F13, where Scenarios 1 and 5 are again compared. Once again, different technologies come out on top. Plastic and $\mathrm{CO}_{2}$ blasting and scarification MOOSE lead a group of several technologies for which the overall PI hovers around 0.9-1.0 for Scenario 1. As the depth of coating reaches 1 in., however, drilling spalling tops the list. It should be noted that the SDA software does not automatically eliminate destructive technologies from consideration when no substrate removal is indicated. Rather, the program allows the user to see all options and to eliminate unwanted choices individually. For this reason, a destructive technology might be rated well for a job requiring surface removal only.

The overall PI is affected not only by the PIs generated from the model, but also by the relative weight the user defines for the five PIs that combine to form the overall PI. The user's ability to specify the relative importance of each area of performance renders the model's output more sensitive to individual circumstances. This is illustrated in Figure F14, where the overall PI is depicted first as the sum of the component PIs (giving equal weight to each) and second as the weighted calculation of the SDA program using the priorities indicated in Scenario 14. The former indicates that Drilling Spalling and Microwave may be the top technologies to explore further. The latter suggests Mechanical Scabbling and Scarification MOOSE as potential decontamination technologies for Scenario 14. 


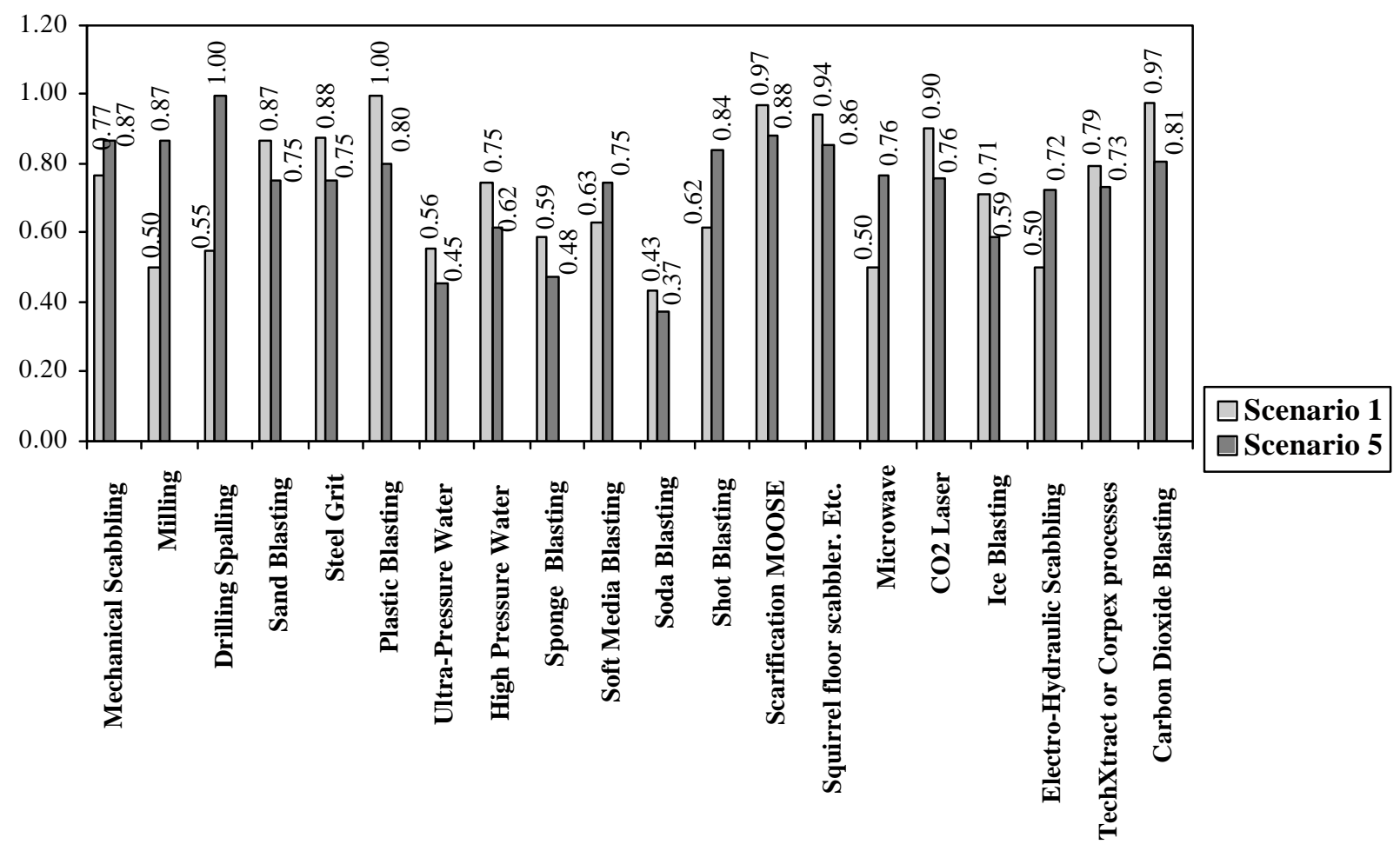

Figure F13. Overall performance indices.

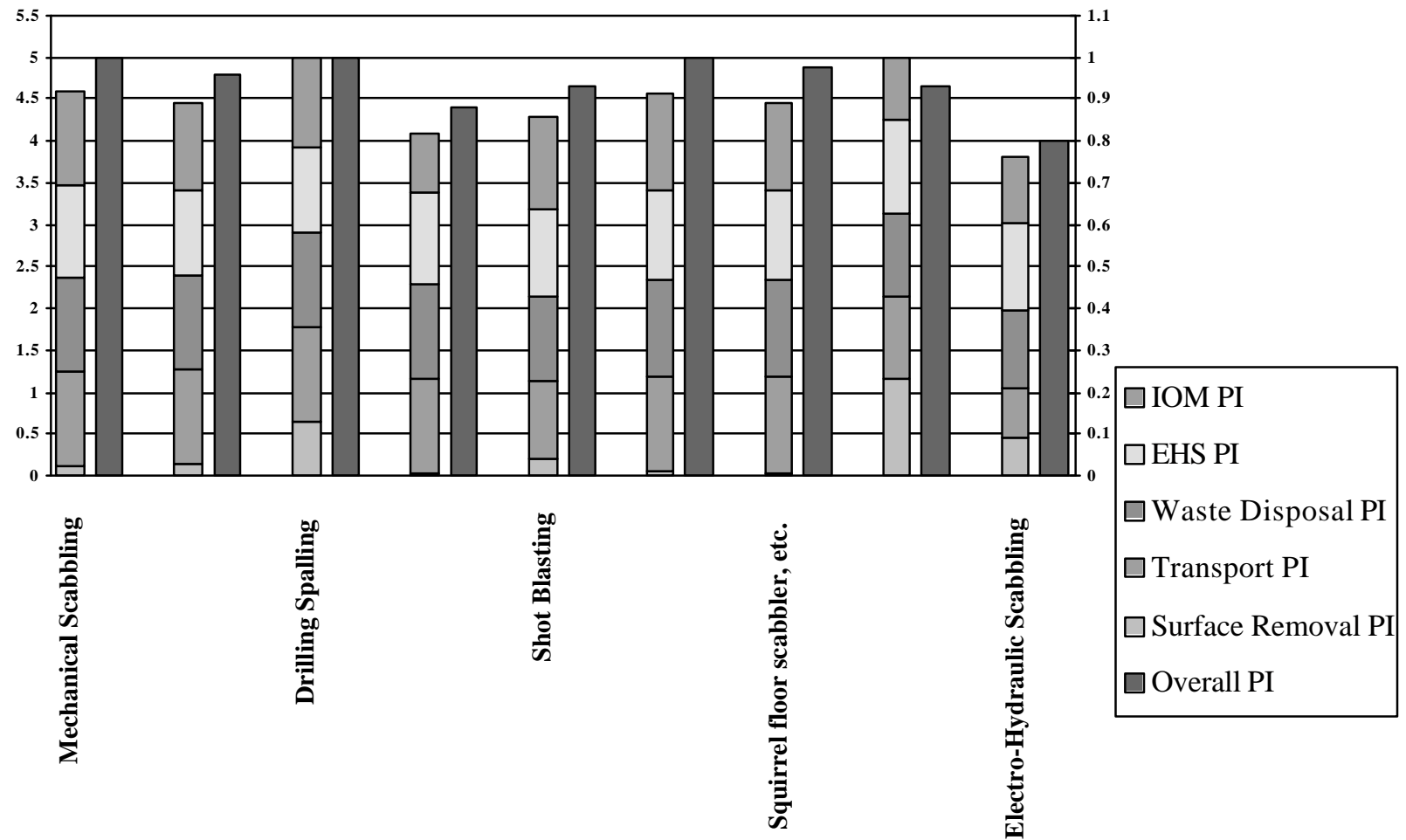

Figure F14. Comparison of unweighted to weighted overall performance index of Scenario 14. 
APPENDIX G

\section{SURFACE DECONTAMINATION ASSISTANT SOFTWARE DESIGN AND OPERATION MANUAL}




\section{DOE DISCLAIMER}

This report was prepared as an account of work sponsored by an agency of the United States Government. Neither the United States Government, nor any agency thereof, nor any of their employees makes any warranty, express or implied, or assumes any legal liability or responsibility for the accuracy, completeness, or usefulness of any information, apparatus, product, or process disclosed or represents that its use would not infringe privately owned rights. Reference herein to any specific commercial product, process, or service by trade name, trademark, manufacturer, or otherwise does not necessarily constitute or imply its endorsement, recommendation, or favoring by the United States Government or any agency thereof. The views and opinions of authors expressed herein do not necessarily state or reflect those of the United States Government or any agency thereof.

\section{ACKNOWLEDGMENT}

This report was prepared with the support of the U.S. Department of Energy (DOE) Federal Energy Technology Center Cooperative Agreement No. DE-FC21-94MC31388. However, any opinions, findings, conclusions, or recommendations expressed herein are those of the authors(s) and do not necessarily reflect the views of DOE.

\section{EERC DISCLAIMER}

LEGAL NOTICE This research report was prepared by the Energy \& Environmental Research Center (EERC), an agency of the University of North Dakota, as an account of work sponsored by DOE. Because of the research nature of the work performed, neither the EERC nor any of its employees makes any warranty, express or implied, or assumes any legal liability or responsibility for the accuracy, completeness, or usefulness of any information, apparatus, product, or process disclosed, or represents that its use would not infringe privately owned rights. Reference herein to any specific commercial product, process, or service by trade name, trademark, manufacturer, or otherwise does not necessarily constitute or imply its endorsement or recommendation by the EERC.

\section{SOFTWARE DISCLAIMER}

LEGAL NOTICE: This computer program was prepared by the Energy \& Environmental Research Center (EERC), an agency of the University of North Dakota, as an account of work sponsored by the U.S. Department of Energy for Contract No. DE-FC21-94MC31388. The services performed, program apparatus, product, or process disclosed and accompanying documentation are provided "as is" without warranty of any kind—expressed, implied, or statutory, including warranties of merchantability and fitness for a particular purpose-except as stated herein. Neither the EERC nor any person acting on behalf of the EERC warrants, guarantees, or makes any representations regarding the use, or the results of the use, of the service performed, program, apparatus, product, or process disclosed, or the accompanying documentation, in terms of correctness, accuracy, reliability, currentness, or otherwise, except as stated herein. Nor does the EERC represent that the use of the service performed, program, apparatus, product, or process disclosed, or the accompanying documentation, will not infringe upon privately owned rights, including copyright, patent, and trademark rights. If the services performed, program, or accompanying documentation are defective, you, and not the EERC or its dealers, distributors, agents, or employees, assume the entire cost of all necessary servicing, repair, or correction except as stated herein. The EERC does not warranty that the operation of the program will be uninterrrupted or error-free. Reference herein to any specific commercial product, process, or service by the trade name, trademark, manufacturer, or otherwise does not necessarily constitute or imply its endorsement or recommendation by the EERC or any sponsor. 


\section{SURFACE DECONTAMINATION ASSISTANT SOFTWARE DESIGN AND OPERATION MANUAL}

\section{INTRODUCTION}

Surface Decontamination Assistant (SDA) is a user-friendly surface decontamination technology comparison software package. SDA uses information assembled in the technology performance dataset user-provided scenario to compare decontamination performance of selected technologies. All outputs from the SDA model are on a relative basis and are intended to be used for comparative purposes only.

SDA has been developed by the Energy \& Environmental Research Center (EERC), a research, consulting, and development organization affiliated with the University of North Dakota in Grand Forks, North Dakota. The Center is recognized as providing energy and environmental research and consulting services for public and private clients in the United States and abroad. Additional information about the EERC is available by calling (701) 777-5000 or by accessing the World Wide Web at www.eerc.und.nodak.edu.

\section{SYSTEM AND SOFTWARE REQUIREMENTS}

SDA will run on a 486 or higher personal computer equipped with a SVGA video adapter with a minimum of $800 \times 600$ resolution and Windows ${ }^{\mathrm{TM}} 95 / \mathrm{NT}$ or higher. It requires a minimum of $8 \mathrm{MB}$ or RAM to operate properly. A 3.5-in. high-density (1.44 MB) disk drive and at least 5 MB or free memory on a hard drive are required to install and run the SDA package. The package consists of 1) the SDA program, which calculates index values and displays them;2) the technology dataset files; and 3) and INSTALL program.

\section{INSTALLATION}

SDA is designed to be installed anywhere on a harddrive. A user-defined directory will be created during installation. To install SDA, execute the INSTALL program found on the disk.

\section{User-Defined Application Scenario}

Upon program execution, the user is presented with the main screen dialog, shown in Figure G1.

Interaction between the user and the software model is done via a series of input dialogs. Once the Run Complete Scenario button shown in Figure G1 is pressed, the user is led through a series of inputs defining the application scenario. The inputs requested of the user by each dialog are listed below. 


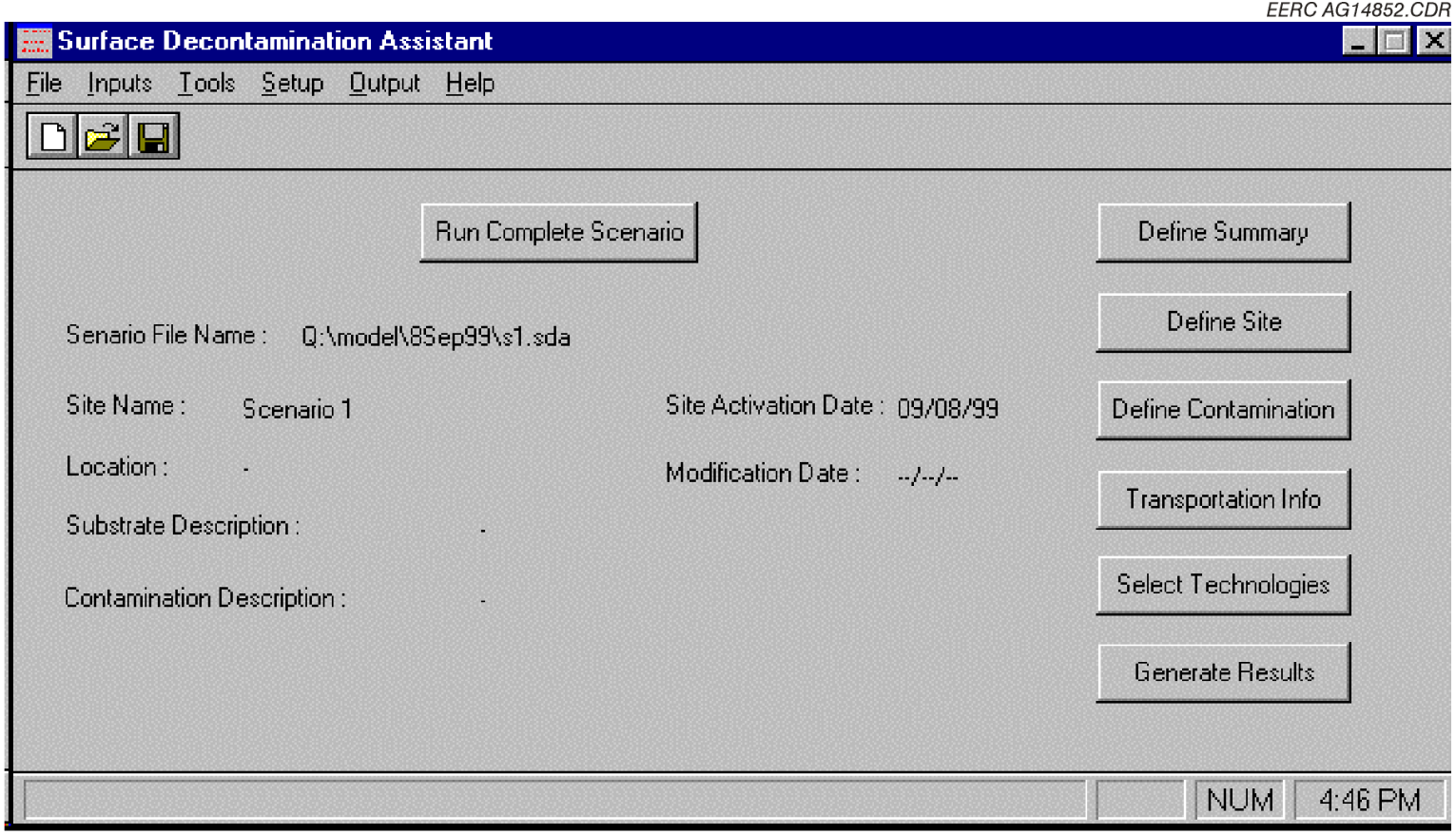

Figure G1. Surface Decontamination Assistant main dialog.

Input Scenario Summary Definition

Site Name:

test site $\# 1$

Location:

Grand Forks, ND

Substrate Description

This building has steel walls heavily contaminated

Contamination Description

Heavy Metals and Radionuclides

$\begin{array}{ll}\text { Site Activation Date } & 11 / 13 / 97 \\ \text { Modification Date } & 11 / 15 / 97\end{array}$

Modification Date

$11715 / 97$

\section{Continue}

Figure G2. Input scenario summary description dialog. 
First, a summary description of the site is entered as listed below and illustrated in Figure G2:
i. $\quad$ Site name
ii. Location of site
iii. General substrate description
iv. General contamination description
v. Scenario (site) activation date
vi. Scenario modification date

Upon pressing the Continue button shown in Figure G2, the user is prompted for more detailed site information as listed below and shown in Figure G3:
i. $\quad$ Surface type
ii. Substrate material
iii. Total area of the surface
iv. Area of hard to reach portions to be decontaminated
v. Thickness of surface coating
vi. Total thickness of surface to be removed

\section{Site Information}

Surface Type

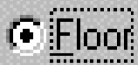

Civiall

C Eeiling

Substrate Material

CSteel

6 Concrete

Total surface area to be removed
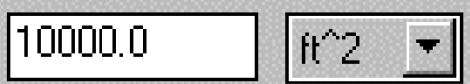

Area hard to reach
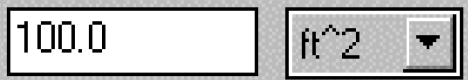

Thickness of coating
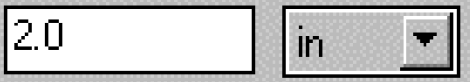

Total thickness of substrate remowal
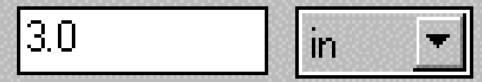

\section{Continute}

Earicel

Figure G3. Site Information dialog. 
Types

Heavy Metals

Hydrocarbons

PCB

Radionuclides

Volatile Organic Compounds

\section{Selected}

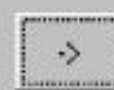

$<-$

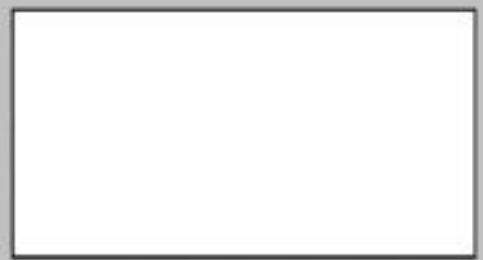

\section{Continue}

\section{Cancel}

Figure G4. General Contamination Definition dialog.

Quantified Contamination Definitions

Total Surface Area from Site Information

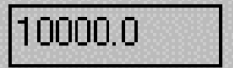

$\mathrm{ft} 2$

Dn-Site capacity to separate solids from liquids

C No

GYes

Percentage of Construction and Demolition Waste

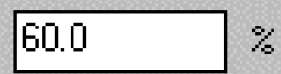

Percentage of Contact Handled Waste

<200 mrem/hr material

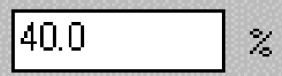

Percentage Area Remote Handled Waste

$>200$ mrem/hr material

Total Percentage

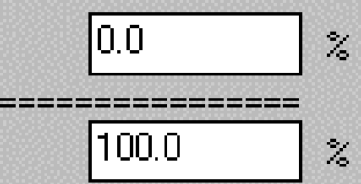

\section{Continue}

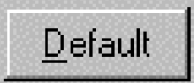

Cancel

Figure G5. Quantified Contamination Definitions input dialog. 
Next, when the Continue button depicted in Figure G3 is pressed, the user can select general categories, as shown in Figure G4.

As before, pressing the Continue button illustrated in Figure G4 brings the user to the input dialog shown in Figure G5, Quantified Contamination Definitions. The program displays the total surface area indicated previously. The inputs needed are estimated surface area percentages of the following waste categories:

i. Construction and demolition (can be sent to a landfill)

ii. Contact-handled $(<200 \mathrm{mrem} / \mathrm{hr})$

iii. Remote-handled ( $>200 \mathrm{mrem} / \mathrm{hr}$ )

and the on-site solid/liquid separation capacity of the facility.

Once the contamination input dialog is completed by pressing the Continue button, the user is prompted for information on the details of transportation to remove waste from the decontamination site. Listed below are the inputs, and the dialog is illustrated in Figure G6.

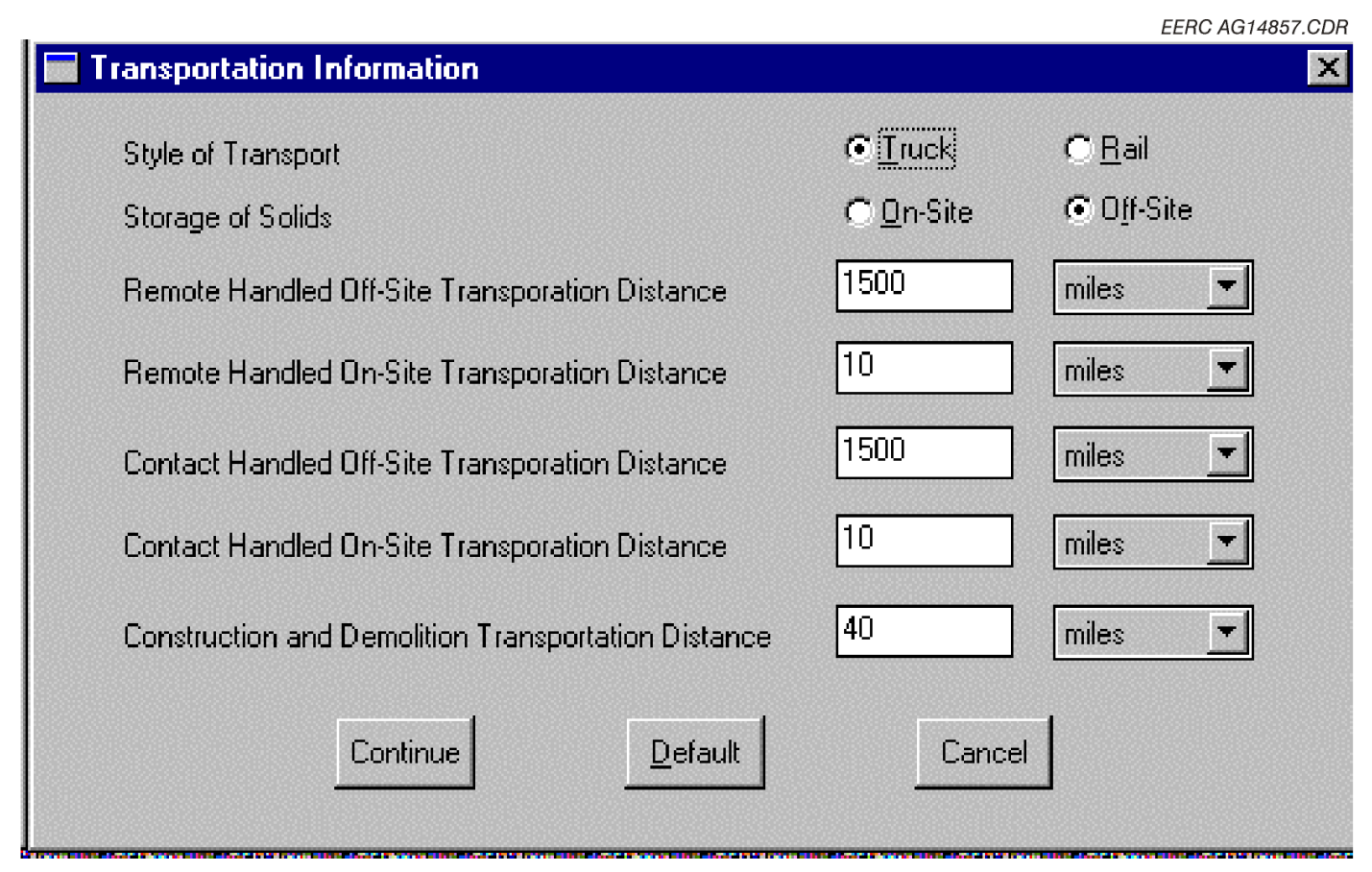

Figure G6. Waste transportation input dialog. 
i. Style of transport

ii. Location of solids storage

iii. Remote-handled waste off-site $\left(\mathrm{RH}_{\text {Off }}\right)$ transport distance

iv. Remote-handled waste on-site $\left(\mathrm{RH}_{\mathrm{On}}\right)$ transport distance

v. Contact-handled waste off-site $\left(\mathrm{CH}_{\text {Off }}\right)$ transport distance

vi. Contact-handled waste on-site $\left(\mathrm{CH}_{\mathrm{Off}}\right)$ transport distance

vii. Construction and demolition (CD) transport distance

Pressing the Continue button shown in Figure G6 brings the user to the surface decontamination Technology Selection dialog depicted in Figure G7. After the user reviews and selects technologies available comparison in the specified scenario, pressing the Continue button illustrated in Figure G7 will return program control to the main input screen shown in Figure G1. At this point, the user can either modify setup inputs for fixed site-specific information or immediately generate technology comparisons.

\section{Setup Inputs for Fixed Site-Specific Information}

Some user inputs not contained in the normal input sequence are accessed via the Setup menu. Selections available under this menu are described below.

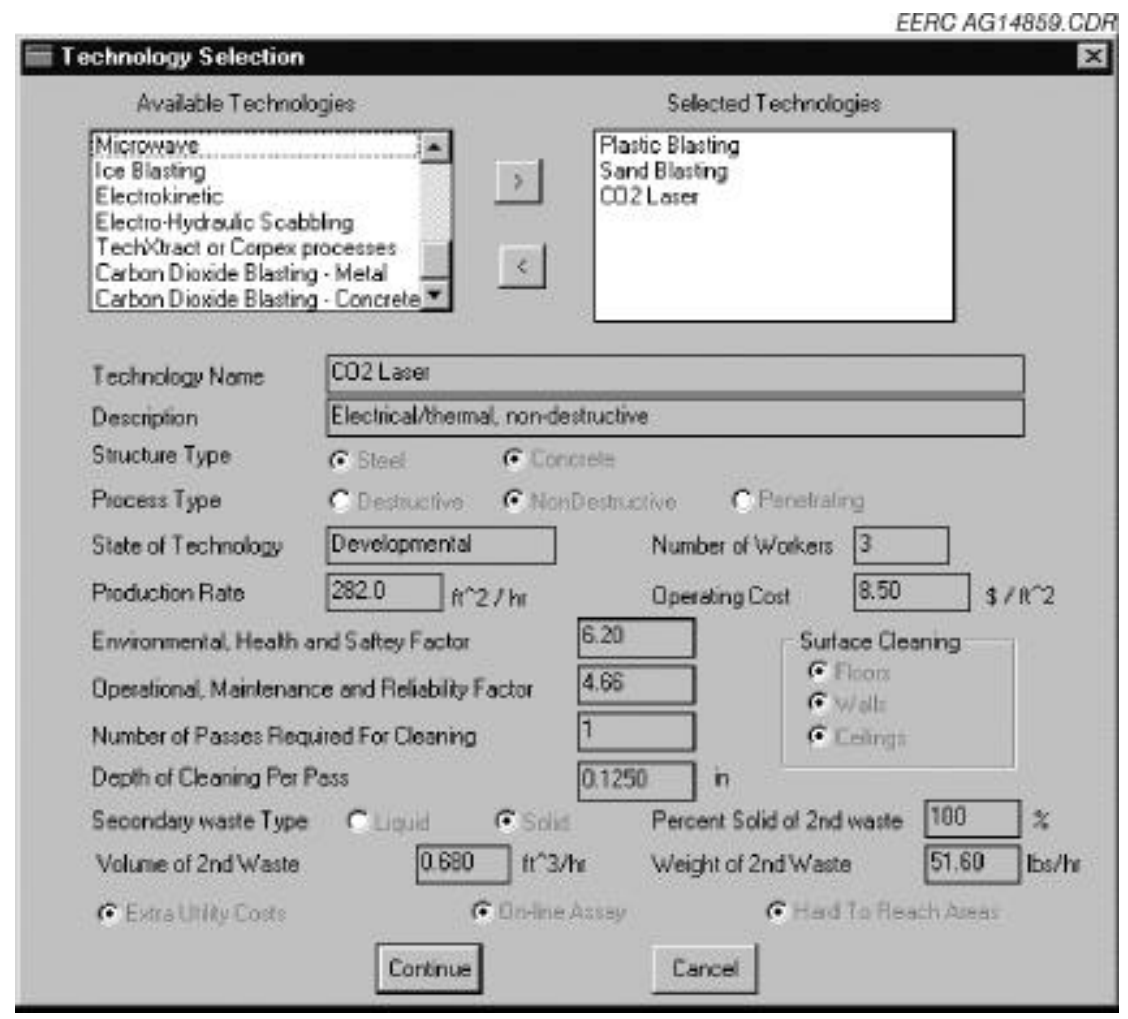

Figure G7. Surface decontamination Technology Selection dialog. 
A dialog is provided to allow the user to specify transportation and disposal costs (Figure G8). The inputs available are as follows:

\author{
Transportation fees \\ i. Truck contact-handled $(\mathrm{CH})$ waste fee \\ ii. Rail CH waste fee \\ iii. Truck remote-handled (RH) waste fee \\ iv. Construction (nonhazardous) waste fee \\ Waste disposal fees \\ i. $\quad \mathrm{CH}$ waste disposal fee \\ ii. RH waste disposal fee \\ iii. Construction (nonhazardous) waste fee disposal fee
}

The user is also allowed to give priority to specific aspects of the surface decontamination process by adjusting the ranking of the categories listed on the dialog box shown in Figure G9. This allows the user to calibrate the model to individual preferences.

\title{
Technology Comparisons
}

Technology comparison outputs are obtained by pressing the Generate Results button shown in Figure G1. The SDA program outputs take two forms.

Upon completion of a program run, the user is presented with a tabular output containing a summary of the technology comparisons, as shown in Figure G10. In addition, the program generates a table containing all user-defined inputs and model results in a comma-delimited ASCII file formatted to allow reading the data into other programs such as spreadsheets, graphics programs, and other data analysis packages.

\section{Conversion of Site Information into Inputs Scenarios for the SDA}

As noted in the previous discussion, there are certain data which the user must supply to the SDA program in order for results to be generated. Any given decontamination site will need to be broken down into a set of input scenarios. A table similar in form to Table F1 in Appendix F can be completed to facilitate entry of data into the program. In addition to playing with priority weights, transportation modes, and distances and costs for disposal of waste, basic site information can be assembled in a number of ways to obtain different results.

The following is an example of how the SDA software can be used to evaluate potential technologies applicable for decontamination of a hypothetical site. This site work includes the decontamination of the interior of a concrete structure made up of several rooms. Partitions within the structure are concrete with exposed metal I-beam support and metal pipes. The area to 
- Transportation Costs

\begin{tabular}{lll|} 
Truck Contact Handled Fee & 4.0 & $\$ /$ mile \\
Rail Contact Handled Fee & 1.91 & $\$ /$ mile \\
Truck Femote Handled Fee & 4.90 & $\$ /$ mile \\
Construction Wiaste Transportation Fee & 1.0 & $\$ /$ mile
\end{tabular}

Disposal Costs

Cantact-Handed Disposal Fee $<200 \mathrm{mrem} / \mathrm{hr}$ material

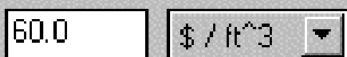

Femote Handled Disposal Fee $>200 \mathrm{mrem} / \mathrm{hr}$ material

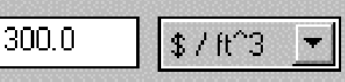

Construction Waste Disposal Fee

$0.26 \quad \$ / \mathrm{tt}^{3}-$

\begin{tabular}{lll} 
Continue $\quad$ Default $\quad$ Cancel \\
\hline
\end{tabular}

Figure G8. Transportation and Disposal Fees.

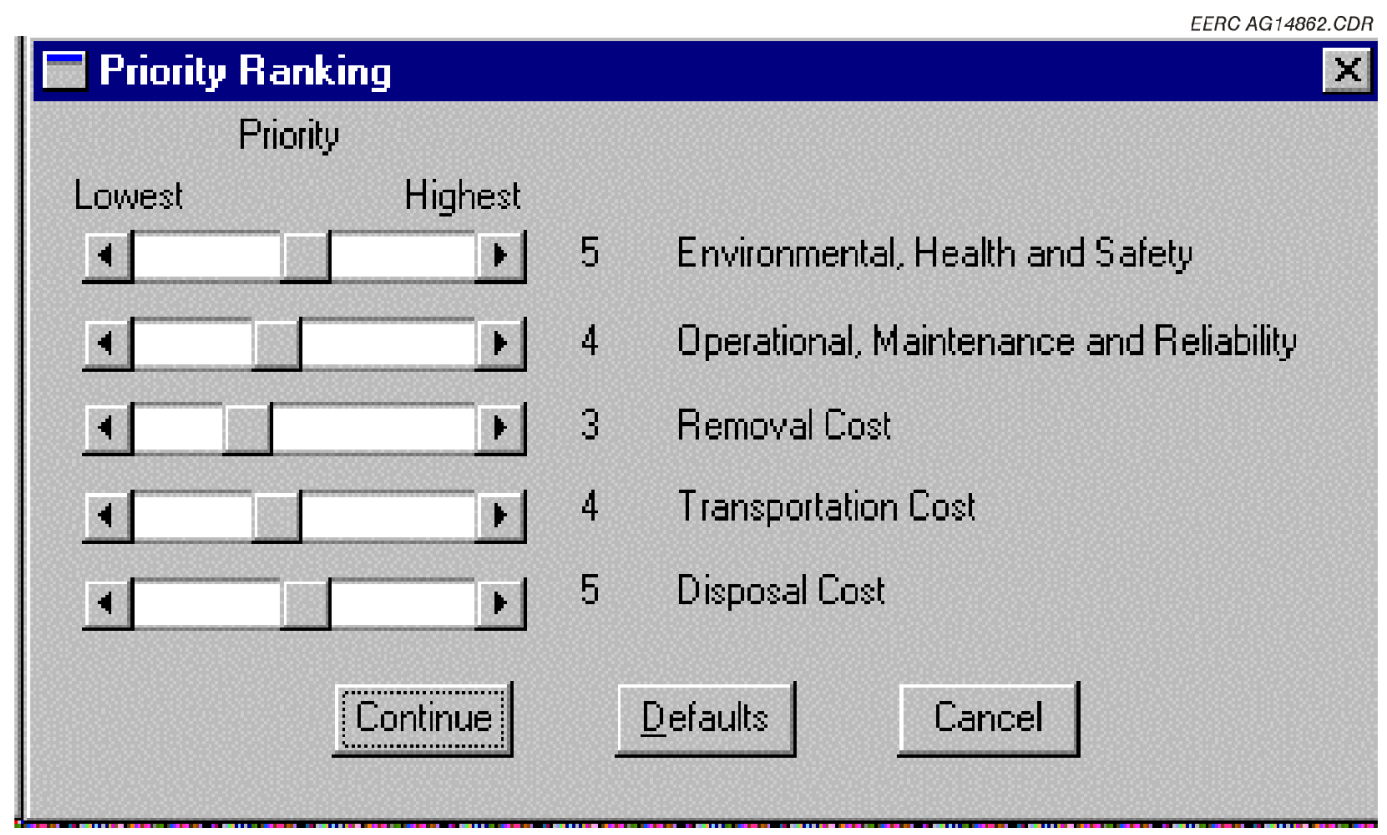

Figure G9. Priority Ranking user input. 


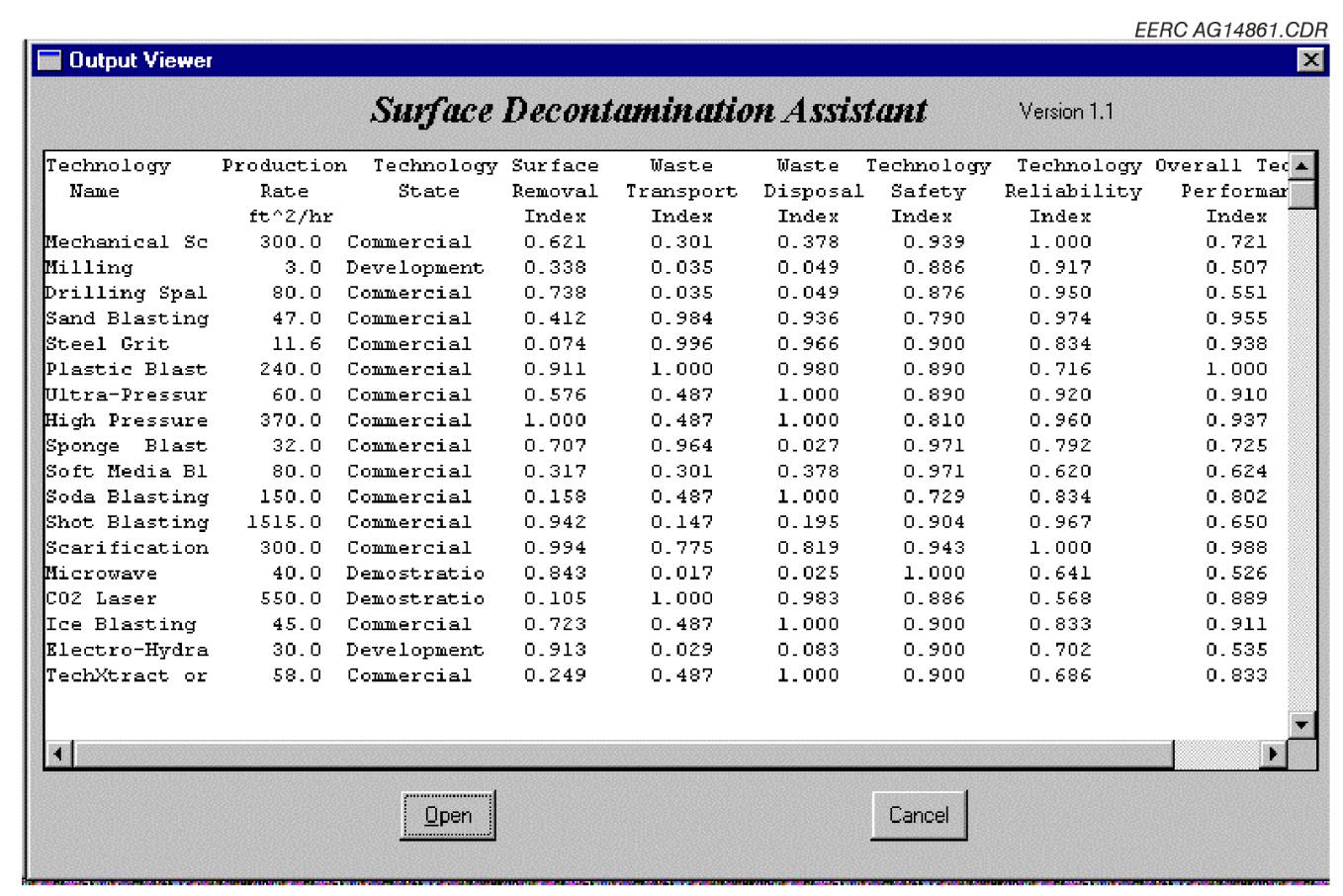

Figure G10. Model results output viewer.

be decontaminated includes $20,000 \mathrm{ft}^{2}$ of floor space, $28,000 \mathrm{ft}^{2}$ of wall space, and $20,000 \mathrm{ft}^{2}$ of ceiling space on concrete, and $5000 \mathrm{ft}^{2}$ on metal surfaces. Because the rooms include corners and cracks, it has been estimated that five percent of the total concrete area and $100 \%$ of the metal area are in the hard-to-reach category. All surfaces have been coated with paints containing $\mathrm{Pb}$ and PCBs to seal in radionuclides. It has been determined that a total of 8 inches of concrete must be removed to ensure complete decontamination. The limit of the depth of contamination, however, has been judged to be 5 inches. There is no capacity to separate solid waste from liquid secondary waste on-site. The transportation mode will be truck, and on-site storage of solid waste is available.

The most obvious use of the SDA program would be to create and run the three scenarios in Table G1. The overall PI for the three concrete scenarios is illustrated in Figure G11. As the figure indicates, this will return a limited ranking of three technologies for concrete removal which are mostly different from the nondestructive technologies recommended for coating removal on metal.

A more detailed approach is suggested by Scheme 2 in Table G2. In this set of scenarios, the surface and substrate removal tasks have been separated. This allows the SDA software to include non-destructive technologies in the surface removal process and to allow the performance of technologies removing, transporting and disposing of non-hazardous waste to be evaluated separately from the hazardous work. As Figure G12 indicates, this will result in a broader selection of technologies available for parts of the work. 


\section{TABLE G1}

Scheme 1 Representation of Decontamination Scenarios

\begin{tabular}{|c|c|c|c|c|c|c|c|c|c|c|}
\hline Scenario & $\begin{array}{c}\text { Cleaning } \\
\text { Surface }\end{array}$ & $\begin{array}{c}\text { Substrat } \\
\mathrm{e}\end{array}$ & Area & $\begin{array}{r}\% \text { Hard } \\
\text { to Reach } \\
\end{array}$ & $\begin{array}{c}\text { Coating } \\
\text { Depth, in. }\end{array}$ & $\begin{array}{l}\text { Substrate } \\
\text { Removal } \\
\text { Depth, in. }\end{array}$ & Contaminants & $\begin{array}{c}\% \text { C\&D } \\
\text { Waste }\end{array}$ & $\begin{array}{l}\% \mathbf{C H} \\
\text { Waste } \\
\end{array}$ & $\begin{array}{l}\% \text { RH } \\
\text { Waste } \\
\end{array}$ \\
\hline $1-1$ & Floors & Concrete & 20000 & 5 & 0.75 & 8 & $\begin{array}{c}\mathrm{Pb}, \mathrm{PCBs}, \\
\text { Radionuclides }\end{array}$ & 0 & 60 & 40 \\
\hline $1-2$ & Walls & Concrete & 28000 & 5 & 0.75 & 8 & $\begin{array}{c}\mathrm{Pb}, \mathrm{PCBs}, \\
\text { Radionuclides }\end{array}$ & 0 & 60 & 40 \\
\hline $1-3$ & Ceilings & Concrete & 20000 & 5 & 0.75 & 8 & $\begin{array}{c}\mathrm{Pb}, \mathrm{PCB} \text {, } \\
\text { Radionuclides }\end{array}$ & 0 & 60 & 40 \\
\hline $1-4$ & Walls & Steel & 5000 & 100 & 0.75 & 0 & $\begin{array}{c}\mathrm{Pb}, \mathrm{PCBs}, \\
\text { Radionuclides }\end{array}$ & 0 & 60 & 40 \\
\hline
\end{tabular}

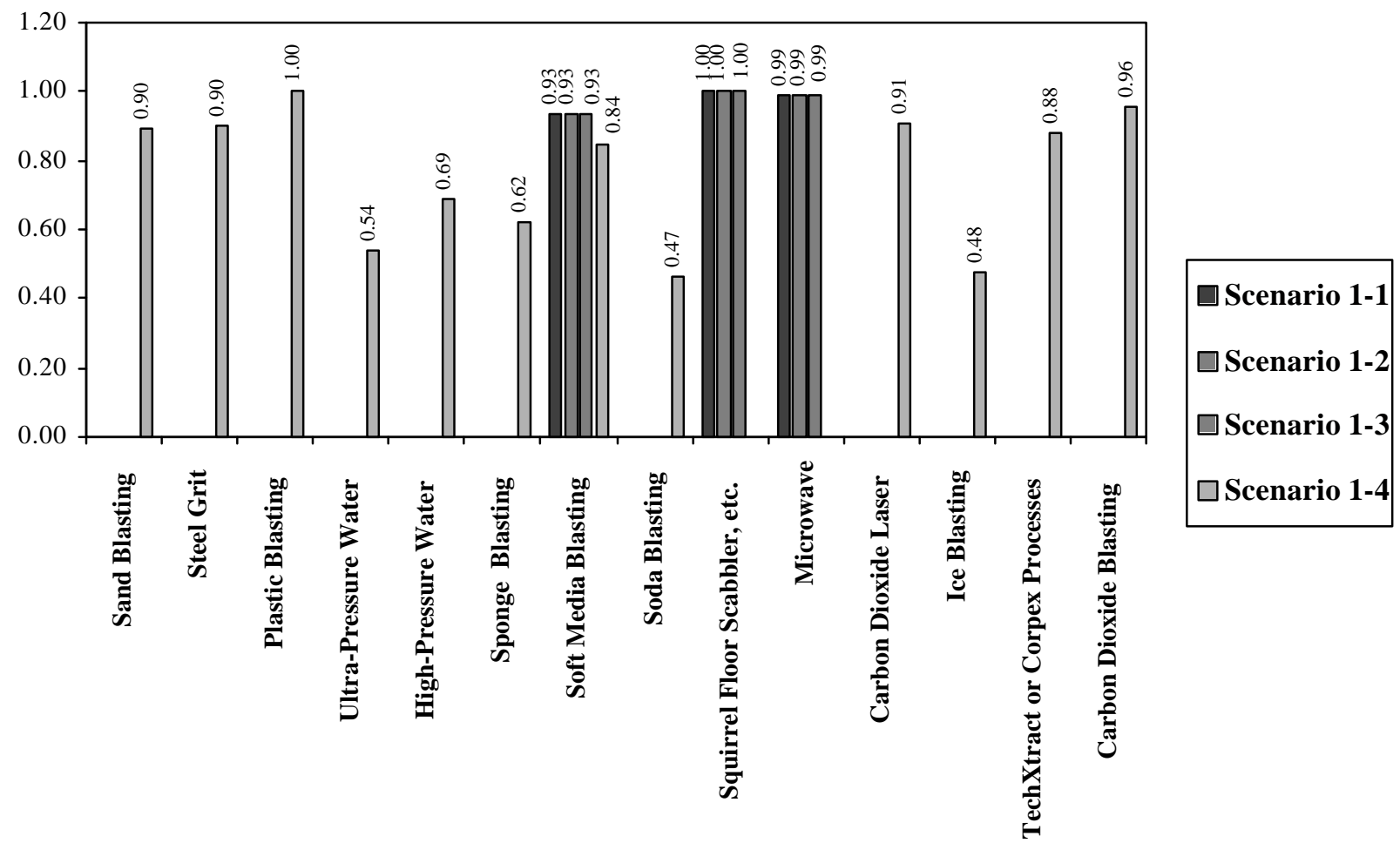

Figure G11. Overall Indices for Scheme 1 (Floors, Walls, and Ceilings). 
TABLE G2

Scheme 2 Representation of Decontamination Scenarios

\begin{tabular}{|c|c|c|c|c|c|c|c|c|c|c|}
\hline Scenario & $\begin{array}{c}\text { Cleaning } \\
\text { surface }\end{array}$ & Substrate & Area & $\begin{array}{c}\% \\
\text { Hard to } \\
\text { Reach } \\
\end{array}$ & $\begin{array}{c}\text { Coating } \\
\text { Depth, in. }\end{array}$ & $\begin{array}{l}\text { Substrate } \\
\text { Removal } \\
\text { Depth, in. }\end{array}$ & Contaminants & $\begin{array}{c}\% \\
\text { C\&D } \\
\text { Waste } \\
\end{array}$ & $\begin{array}{l}\% \mathrm{CH} \\
\text { Waste } \\
\end{array}$ & $\begin{array}{l}\% \text { RH } \\
\text { Waste } \\
\end{array}$ \\
\hline $2-1$ & Floors & Concrete & 20000 & 5 & 0.75 & 0 & $\begin{array}{c}\mathrm{Pb}, \mathrm{PCBs} \\
\text { Radionuclides }\end{array}$ & 0 & 60 & 40 \\
\hline $2-2$ & Floors & Concrete & 20000 & 5 & 0 & 5 & $\begin{array}{c}\mathrm{Pb}, \mathrm{PCBs} \\
\text { Radionuclides }\end{array}$ & 10 & 50 & 40 \\
\hline $2-3$ & Floors & Concrete & 20000 & 5 & 0 & 3 & none & 100 & 0 & 0 \\
\hline $2-4$ & Walls & Concrete & 28000 & 5 & 0.75 & 0 & $\begin{array}{c}\mathrm{Pb}, \mathrm{PCBs} \\
\text { Radionuclides }\end{array}$ & 0 & 60 & 40 \\
\hline $2-5$ & Walls & Concrete & 28000 & 5 & 0 & 5 & $\begin{array}{c}\mathrm{Pb}, \mathrm{PCBs} \\
\text { Radionuclides }\end{array}$ & 10 & 50 & 40 \\
\hline $2-6$ & Walls & Concrete & 28000 & 5 & 0 & 3 & none & 100 & 0 & 0 \\
\hline $2-7$ & Ceilings & Concrete & 20000 & 5 & 0.75 & 0 & $\begin{array}{c}\mathrm{Pb}, \mathrm{PCBs}, \\
\text { Radionuclides }\end{array}$ & 0 & 60 & 40 \\
\hline $2-8$ & Ceilings & Concrete & 20000 & 5 & 0 & 5 & $\begin{array}{c}\mathrm{Pb}, \mathrm{PCBs} \\
\text { Radionuclides }\end{array}$ & 10 & 50 & 40 \\
\hline $2-9$ & Ceilings & Concrete & 20000 & 5 & 0 & 3 & none & 100 & 0 & 0 \\
\hline $2-10$ & Walls & Steel & 5000 & 100 & 0.75 & 0 & $\begin{array}{c}\mathrm{Pb}, \mathrm{PCBs}, \\
\text { Radionuclides }\end{array}$ & 0 & 60 & 40 \\
\hline
\end{tabular}

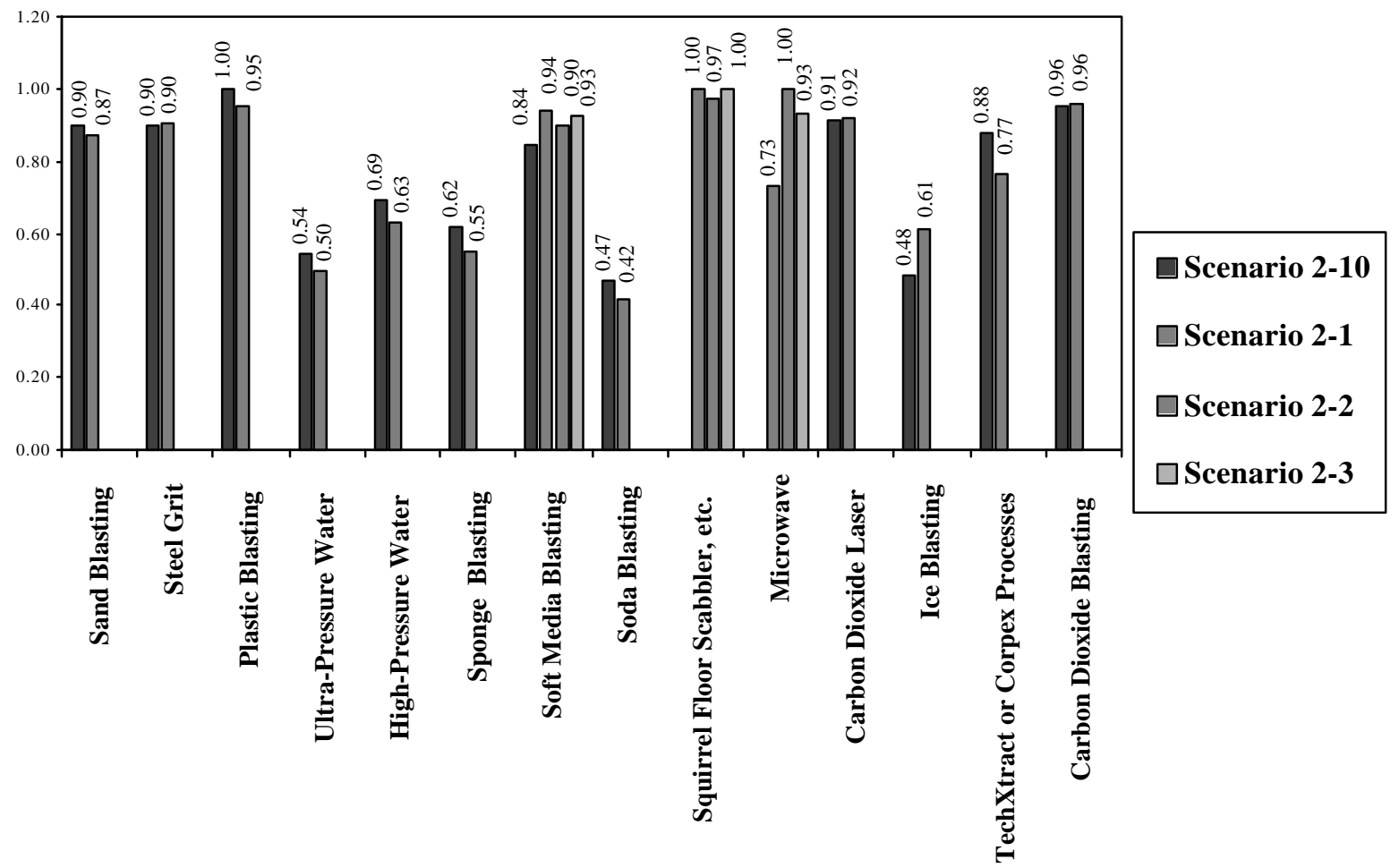

Figure G12. Overall indices for Scheme 2 (Floor and Metal Scenarios) 
The most detailed approach would be to subdivide each decontamination region from Scheme 2 into hard-to-reach and not hard-to-reach areas. The scheme for this approach is delineated in Table G3. The overall performance indices of three scenarios from this scheme are depicted in Figure G13. This will result in a greatest number of technologies examined and a more comprehensive analysis of technologies to recommend for further consideration.

Finally, if the user determines that it is not necessary to remove the surface separately from the contaminated substrate, two levels of removal, rather than the three specified in Table G3 could be set up. In this case, the user would divide the work as presented by Scheme 4 in Table G4. As the overall PIs in Figure G14 show, the results from this scheme would again offer a greater number of technology options to explore than the results from the first two tables.

\section{TABLE G3}

Scheme 3 Representation of Decontamination Scenarios

\begin{tabular}{|c|c|c|c|c|c|c|c|c|c|c|}
\hline Scenario & $\begin{array}{c}\text { Cleaning } \\
\text { Surface }\end{array}$ & Substrate & Area & $\begin{array}{c}\% \text { Hard to } \\
\text { Reach }\end{array}$ & $\begin{array}{c}\text { Coating } \\
\text { Depth, in. }\end{array}$ & $\begin{array}{l}\text { Substrate } \\
\text { Removal } \\
\text { Depth, in. }\end{array}$ & Contaminants & $\begin{array}{c}\% \text { C\&D } \\
\text { Waste }\end{array}$ & $\begin{array}{l}\% \mathrm{CH} \\
\text { Waste } \\
\end{array}$ & $\begin{array}{l}\% \text { RH } \\
\text { Waste } \\
\end{array}$ \\
\hline $3-1$ & Floors & Concrete & 19000 & 0 & 0.75 & 0 & $\begin{array}{c}\mathrm{Pb}, \mathrm{PCBs}, \\
\text { Radionuclides }\end{array}$ & 0 & 60 & 40 \\
\hline $3-2$ & Floors & Concrete & 1000 & 100 & 0.75 & 0 & $\begin{array}{c}\mathrm{Pb}, \mathrm{PCBs}, \\
\text { Radionuclides }\end{array}$ & 0 & 60 & 40 \\
\hline $3-3$ & Floors & Concrete & 19000 & 0 & 0 & 5 & $\begin{array}{c}\text { Pb, PCBs, } \\
\text { Radionuclides }\end{array}$ & 10 & 50 & 40 \\
\hline $3-4$ & Floors & Concrete & 1000 & 100 & 0 & 5 & $\begin{array}{c}\mathrm{Pb}, \mathrm{PCBs}, \\
\text { Radionuclides }\end{array}$ & 10 & 50 & 40 \\
\hline $3-5$ & Floors & Concrete & 19000 & 0 & 0 & 3 & none & 100 & 0 & 0 \\
\hline $3-6$ & Floors & Concrete & 1000 & 100 & 0 & 3 & none & 100 & 0 & 0 \\
\hline $3-7$ & Walls & Concrete & 26600 & 0 & 0.75 & 0 & $\begin{array}{c}\text { Pb, PCBs, } \\
\text { Radionuclides }\end{array}$ & 0 & 60 & 40 \\
\hline $3-8$ & Walls & Concrete & 1400 & 100 & 0.75 & 0 & $\begin{array}{c}\text { Pb, PCBs, } \\
\text { Radionuclides }\end{array}$ & 0 & 60 & 40 \\
\hline $3-9$ & Walls & Concrete & 26600 & 0 & 0 & 5 & $\begin{array}{c}\mathrm{Pb}, \mathrm{PCBs}, \\
\text { Radionuclides }\end{array}$ & 10 & 50 & 40 \\
\hline $3-10$ & Walls & Concrete & 1400 & 100 & 0 & 5 & $\begin{array}{c}\mathrm{Pb}, \mathrm{PCBs}, \\
\text { Radionuclides }\end{array}$ & 10 & 50 & 40 \\
\hline $3-11$ & Walls & Concrete & 26600 & 0 & 0 & 3 & none & 100 & 0 & 0 \\
\hline $3-12$ & Walls & Concrete & 1400 & 100 & 0 & 3 & none & 100 & 0 & 0 \\
\hline $3-13$ & Ceilings & Concrete & 19000 & 0 & 0.75 & 0 & $\begin{array}{c}\mathrm{Pb}, \mathrm{PCBs}, \\
\text { Radionuclides }\end{array}$ & 0 & 60 & 40 \\
\hline $3-14$ & Ceilings & Concrete & 1000 & 100 & 0.75 & 0 & $\begin{array}{c}\mathrm{Pb}, \mathrm{PCBs}, \\
\text { Radionuclides }\end{array}$ & 0 & 60 & 40 \\
\hline $3-15$ & Ceilings & Concrete & 19000 & 0 & 0 & 5 & $\begin{array}{c}\mathrm{Pb}, \mathrm{PCBs}, \\
\text { Radionuclides }\end{array}$ & 10 & 50 & 40 \\
\hline $3-16$ & Ceilings & Concrete & 1000 & 100 & 0 & 5 & $\begin{array}{c}\mathrm{Pb}, \mathrm{PCBs}, \\
\text { Radionuclides }\end{array}$ & 10 & 50 & 40 \\
\hline $3-17$ & Ceilings & Concrete & 19000 & 0 & 0 & 3 & none & 100 & 0 & 0 \\
\hline $3-18$ & Ceilings & Concrete & 1000 & 100 & 0 & 3 & none & 100 & 0 & 0 \\
\hline $3-19$ & Walls & Steel & 5000 & 100 & 0.75 & 0 & $\begin{array}{c}\mathrm{Pb}, \mathrm{PCBs}, \\
\text { Radionuclides }\end{array}$ & 0 & 60 & 40 \\
\hline
\end{tabular}




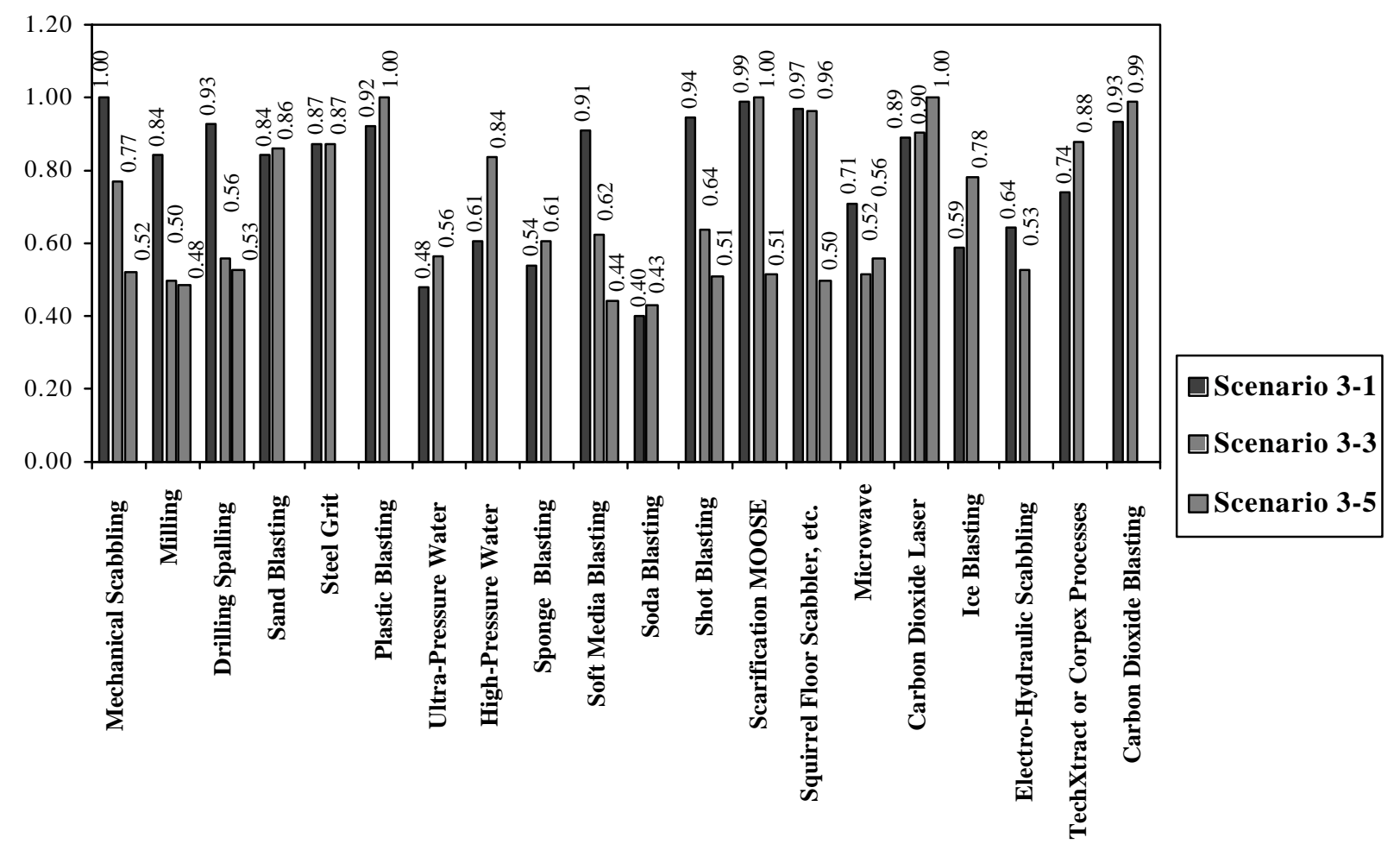

Figure G13. Overall indices for Scheme 3 (floor scenarios). 


\section{TABLE G4}

Scheme 4 Representation of Decontamination Scenarios

\begin{tabular}{|c|c|c|c|c|c|c|c|c|c|c|}
\hline Scenario & $\begin{array}{c}\text { Cleaning } \\
\text { Surface }\end{array}$ & Substrate & Area & $\begin{array}{l}\% \text { Hard } \\
\text { to } \\
\text { Reach } \\
\end{array}$ & $\begin{array}{c}\text { Coating } \\
\text { Depth, in. }\end{array}$ & $\begin{array}{l}\text { Substrate } \\
\text { Removal } \\
\text { Depth, in. }\end{array}$ & Contaminants & $\begin{array}{c}\% \\
\text { C\&D } \\
\text { Waste } \\
\end{array}$ & $\begin{array}{l}\% \mathrm{CH} \\
\text { Waste }\end{array}$ & $\begin{array}{l}\% \mathrm{RH} \\
\text { Waste }\end{array}$ \\
\hline $4-1$ & Floors & Concrete & 19000 & 0 & 0.75 & 5 & $\begin{array}{c}\mathrm{Pb}, \mathrm{PCBs} \\
\text { Radionuclides }\end{array}$ & 0 & 60 & 40 \\
\hline $4-2$ & Floors & Concrete & 1000 & 100 & 0.75 & 5 & $\begin{array}{c}\mathrm{Pb}, \mathrm{PCBs} \\
\text { Radionuclides }\end{array}$ & 0 & 60 & 40 \\
\hline $4-3$ & Floors & Concrete & 19000 & 0 & 0 & 3 & none & 100 & 0 & 0 \\
\hline $4-4$ & Floors & Concrete & 1000 & 100 & 0 & 3 & none & 100 & 0 & 0 \\
\hline $4-5$ & Walls & Concrete & 26600 & 0 & 0.75 & 5 & $\begin{array}{c}\mathrm{Pb}, \mathrm{PCBs} \\
\text { Radionuclides }\end{array}$ & 0 & 60 & 40 \\
\hline $4-6$ & Walls & Concrete & 1400 & 100 & 0.75 & 5 & $\begin{array}{c}\mathrm{Pb}, \mathrm{PCBs} \\
\text { Radionuclides }\end{array}$ & 0 & 60 & 40 \\
\hline $4-7$ & Walls & Concrete & 26600 & 0 & 0 & 3 & none & 100 & 0 & 0 \\
\hline $4-8$ & Walls & Concrete & 1400 & 100 & 0 & 3 & none & 100 & 0 & 0 \\
\hline $4-9$ & Ceilings & Concrete & 19000 & 0 & 0.75 & 5 & $\begin{array}{c}\mathrm{Pb}, \mathrm{PCBs} \\
\text { Radionuclides }\end{array}$ & 0 & 60 & 40 \\
\hline $4-10$ & Ceilings & Concrete & 1000 & 100 & 0.75 & 5 & $\begin{array}{c}\mathrm{Pb}, \mathrm{PCBs} \\
\text { Radionuclides }\end{array}$ & 0 & 60 & 40 \\
\hline $4-11$ & Ceilings & Concrete & 19000 & 0 & 0 & 3 & none & 100 & 0 & 0 \\
\hline $4-12$ & Ceilings & Concrete & 1000 & 100 & 0 & 3 & none & 100 & 0 & 0 \\
\hline $4-13$ & Walls & Steel & 5000 & 100 & 0.75 & 0 & $\begin{array}{c}\mathrm{Pb}, \mathrm{PCBs}, \\
\text { Radionuclides }\end{array}$ & 0 & 60 & 40 \\
\hline
\end{tabular}




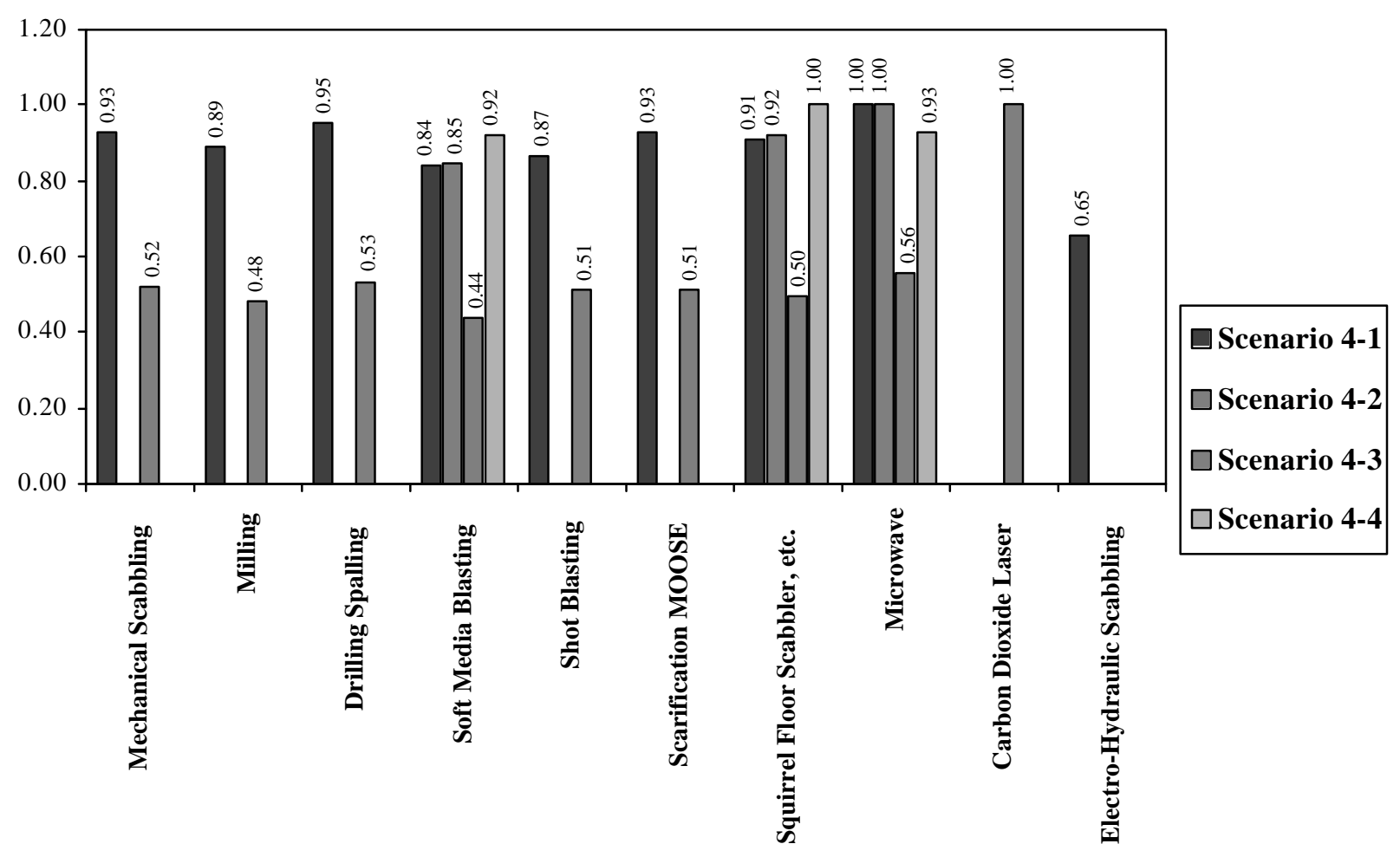

Figure G14. Overall indices for Scheme 4 (floor scenarios). 